\title{
CONTABILIZANDO A EROSÃODO SOLO: UM AJUSTE AMBIENTAL PARA O PRODUTO BRUTO AGROPECUÁRIO PAULISTA
}

\author{
GUILHERME SORIA BASTOS FILHO \\ Engenheiro Agrônomo
}

Orientador: Prof. Dr. RICARDO SHIROTA

\begin{abstract}
Dissertação apresentada à Escola Superior de Agricultura "Luiz de Queiroz", da Universidade de São Paulo, para a obtenção do título de Mestre em Agronomia, Área de Concentração: Economia Agrária.
\end{abstract}

P I R A C I C A B A

Estado de São Paulo - Brasil

Dezembro - 1995 
Dados Internacionais de Catalogação na Publicação (CIP)

DIVISÃo DE BIBLIOTECA E DOCUMENTAÇÃOO - Campus "Luiz de Queiroz"/USP

Bastos Filho, Guilherme Soria

Contabilizando a erosão do solo: um ajuste ambiental para o produto bruto agropecuário paulista / Guilherme Soria Bastos Filho. - Piracicaba, 1995.

$127 p$.

Dissertação (Mestrado) - - Escola Superior de Agricultura Luiz de Queiroz, 1996. Bibliografia.

1. Agropecuária - Impacto ambiental - São Paulo (Estado) 2 Deseṇvolvimento econômico sustentado 3. Erosão 4. Solo - Degradação - Aspecto econômico I. Título 


\title{
CONTABILIZANDO A EROSÃODO SOLO: UM AJUSTE AMBIENTAL PARA O PRODUTO BRUTO AGROPECUÁRIO PAULISTA
}

\author{
GUILHERME SORIA BASTOS FILHO
}

Aprovada em 04:03.1996

Comissão julgadora:

Prof. Dr. Ricárdo Shirota. :

ESALQ/USP

Prof. Dr. Carlos José Caetano Bacha

ESALQ/USP

Prof. Dr. Fernando Antônio da Silveira Rocha

DER/UFV

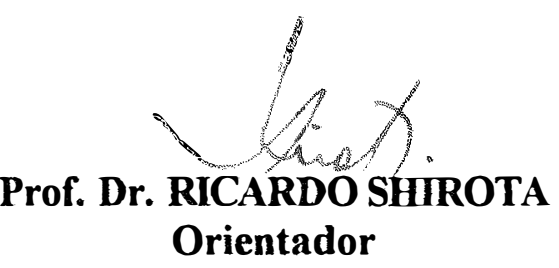


Para Isolina, Guilherme, Carmen, Gustavo e Cíntia, com todo carinho, dedico. 


\section{AGRADECIMENTOS}

À minha familia, pelo estímulo e suporte que sempre deram à minha vida, aos meus estudos, à minha carreira.

Ao amigo e professor Paulo Cidade, a quem admiro e respeito profundamente.

Ao meu orientador, com quem pretendo continuar trabalhando nesta área.

Ao professor Carlos Bacha, pelas valiosas contribuições e pelas revisões feitas desde o projeto original desta dissertação.

Ao professor Ronaldo Serôa, pelas referências fornecidas que me proporcionaram subsidios para este trabalho.

Aos pesquisadores Isabela Clerici e João Marques e ao professor Peter May, pelas revisões e sugestões feitas.

Aos meus colegas de mestrado, pela agradável companhia durante a estada em Piracicaba. A todos desejo muito sucesso em suas carreiras.

À bibliotecária Angélica, pela revisão criteriosa das citações bibliográficas. À bibliotecária $\mathrm{Lu}$, pela atenção e simpatia com que sempre fui recebido.

Ả professora Carmen, minha mãe, pelas revisões gramaticais e ortográficas.

Ao amigo Lagarto, pela hospitalidade com que me recebeu em sua residência.

À professora Irani Grassiotto e ao professor José Ricardo Cure, a quem devo pelo início da minha formação científica.

$\mathrm{E}$, finalmente ao $\mathrm{CNPq}$, pelo apoio financeiro que vem-me concedendo nos trabalhos de pesquisa desde a minha graduação em agronomia. 
"Não se deve esperar que todo o espectro de questões ambientais venha a ser coberto. É fundamental introduzir logo aquilo que se conhece, ajustando os dados de renda, parcial e gradualmente, e não ficar esperando até que todas as perguntas sejam respondidas." Salah El Serafy 


\section{S U M Á R I O}

\section{Página}

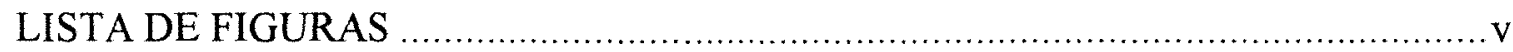

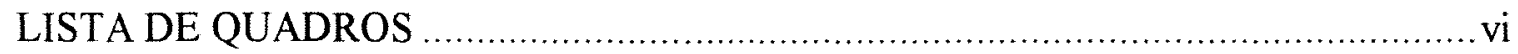

LISTA DE TABELAS .............................................................................. vii

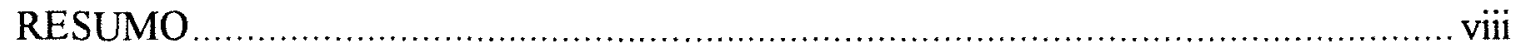

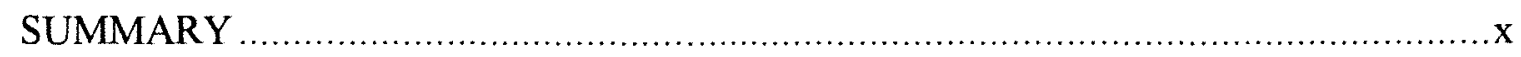

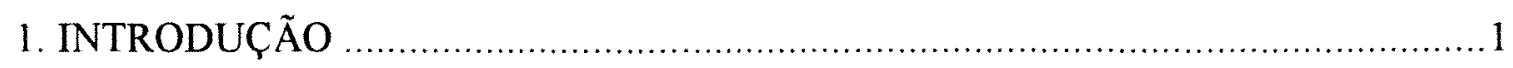

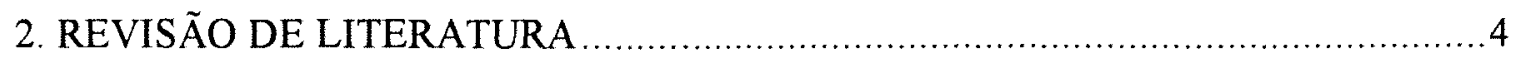

2.1. A agricultura brasileira e paulista: da Revolução Verde ao período em

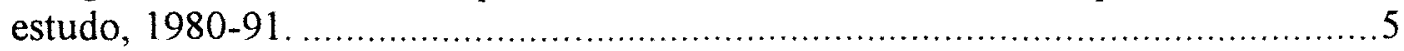

2.2. A teoria econômica tradicional e a valoração dos recursos naturais .................... 17

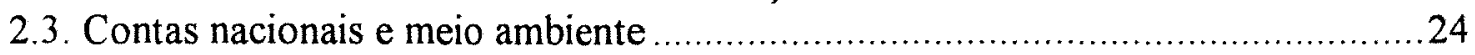

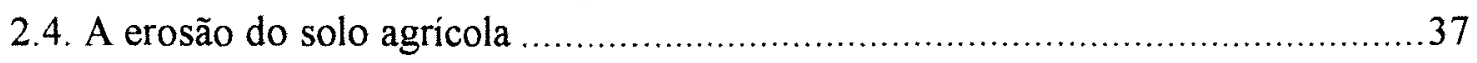

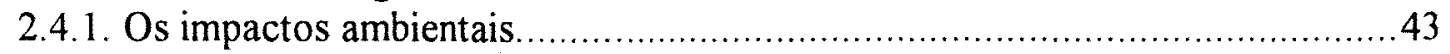

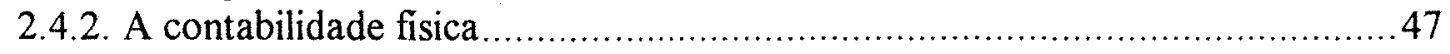

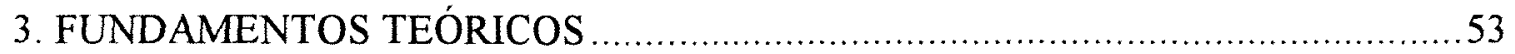

3.1. Métodos de avaliação econômica dos impactos da erosão do solo .....................53

3.2. Metodologias para ajustar ambientalmente a renda nacional ...........................6. 62

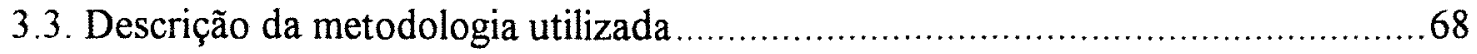

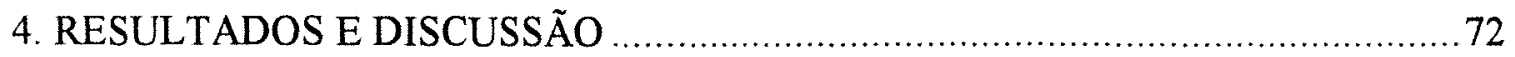

4.1. A estimativa da degradação do recurso solo ............................................. 72

4.2. O ajuste ambiental do PIB agropecuário paulista ................................... 86

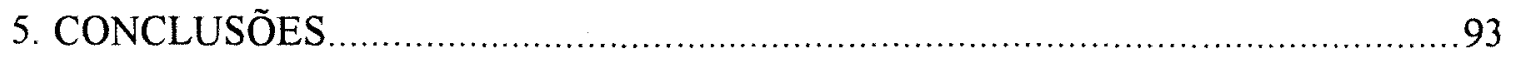

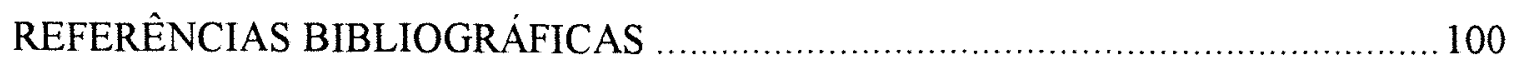

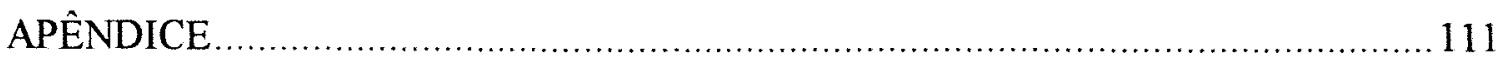




\section{LISTA DE FIGURAS}

\section{Página}

Figura 1. Índice do produto físico total e agropecuário do Brasil e do Estado de São Paulo, 1980/91.

Figura 2. O sistema econômico, seus subconjuntos e o sistema de contas nacionais.

Figura 3. O uso do solo no Estado de São Paulo em 1980, 1984, 1988 e 1991.

Figura 4. Esquema ilustrativo do impacto da atividade agropecuária sobre o meio ambiente.

Figura 5. A depreciação do recurso solo pela erosão (percentagem em relação ao PIB Agropecuário de São Paulo)

Figura 6. Comparação de tendências: perdas monetárias vs. perdas fisicas. 


\section{LISTA DE QUADROS}

Página

Quadro 1. Estrutura do Sistema de Contas Ecológicas e Econômicas proposta pela UNSO.

Quadro 2. Taxas de formação natural do solo, erosão natural e induzida pelo homem. 38

Quadro 3. Idades relativas dos recursos naturais.

Quadro 4. Classes de capacidade de uso das terras do Estado de São Paulo, distribuição, áreas abrangidas, declividades, uso intenso mais recomendado e grau de limitação para este uso.

Quadro 5. Impactos da erosão para fora da unidade produtiva. 48

Quadro 6. Algumas estimativas monetárias de depreciação do recurso solo. 61

Quadro 7. Efeito sobre o PIB pela inclusão de um programa de proteção ambiental (em unidades monetárias). 


\section{LISTA DE TABELAS}

Página

Tabela 1. Indices de consumo aparente de insumos agrícolas selecionados 1975/91 $(1975=100)$ e percentagem do pessoal ocupado na agricultura

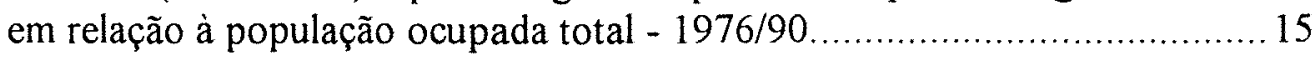

Tabela 2. Evolução do uso do território paulista, 1980/91 (em 1.000 ha) ..................73

Tabela 3. Taxas médias de perda de solo por erosão, em t/ha/ano, nas principais culturas do Estado de São Paulo.

Tabela 4. Evolução das perdas físicas de solo pela erosão, em função do uso do solo no Estado de São Paulo, em 1.000 t/ano. .................................. 75

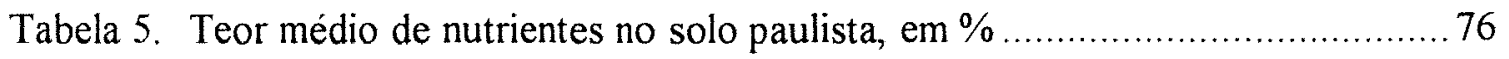

Tabela 6. Valores de conversão e perdas de nutrientes em fertilizantes comerciais...... 76

Tabela 7. Perdas de solo, em t/ha/a, em termos de nutrientes e em equivalentefertilizantes, 1990/91

Tabela 8. Evolução dos preços dos fertilizantes por tonelada, médias anuais reais, em US\$(1991), 1980/91.

Tabela 9. Custos médios anuais reais de aplicação de fertilizantes segundo o uso do solo no Estado de São Paulo, em US\$ (1991)/t.

Tabela 10. Custos médios anuais reais de aplicação de calcário segundo o uso do solo no Estado de São Paulo, em US\$ (1991)/t.

Tabela 11. Estimativas do valor econômico da depreciação do recurso solo, no Estado de São Paulo, em US\$ mil (1991)/ano......

Tabela 12. Estimativas médias do valor econômico da depreciação do recurso solo, no Estado de São Paulo, em US\$ mil (1991)/ha/ano, por uso do solo.

Tabela 13. O PIB agropecuário do Estado de São Paulo ajustado ambientalmente. .88 
viii.

\title{
CONTABILIZANDO A EROSÃO DO SOLO: UM AJUSTE AMBIENTAL PARA O PRODUTO BRUTO AGROPECUÁRIO PAULISTA
}

\author{
Autor: GUILHERME SORIA BASTOS FILHO \\ Orientador: Prof. Dr. RICARDO SHIROTA
}

\section{RESUMO}

O presente trabalho consiste num estudo de valoração econômica do meio ambiente, tratando em específico do caso da depreciação do recurso solo pela erosão, causada pelo setor agropecuário paulista. O estudo cobre os anos de 1980 a 1991, um período marcado por uma grande instabilidade econômica no país. Surpreendentemente, neste período o setor agropecuário apresentou um expressivo crescimento, comportando-se em sentido contrário ao da economia como um todo. Há evidências que a pressão sobre o recurso solo tenha-se agravado no início da década de oitenta, em função do período recessivo pelo qual a economia passou. O Estado de São Paulo foi escolhido como a região de estudo, pela importância que possui na economia nacional, bem como pela disponibilidade de dados.

A pressuposição básica do presente trabalho é a de que os tradicionais indicadores econômicos de renda (e.g. produto interno bruto, renda, etc) são superestimados pela não contabilização da depreciação/exaustão do capital ambiental/natural. Essas perdas são muitas vezes resultantes de altas taxas de crescimento 
não sustentáveis das economias, levando à falsa impressão de aumento da renda nacional. Por este motivo, deveriam ser contabilizadas e descontadas dos indicadores usualmente utilizados para medir a renda de uma nação.

Apesar dos inúmeros custos gerados pela erosão do solo, o presente trabalho estima o valor das perdas de nutrientes (nitrogênio, fósforo, potássio, cálcio e magnésio), contabilizando-o como uma proxy da degradação do recurso solo. $\mathrm{O}$ valor médio anual da depreciação do solo, calculado por este método nos anos de 1980 a 1991, foi de US\$176 milhões. Em termos contábeis, a inexistência ou falta de metodologia definida para se determinar o Produto Interno Líquido (PIL) fez com que o ajuste ambiental fosse feito sobre o Produto Interno Bruto (PIB), indicador este mais utilizado em análises macroeconômicas. Ao longo do período estudado, a degradação do solo chegou a representar 5,23\% do PIB agropecuário de São Paulo.

palavras-chave: contabilidade ambiental; erosão do solo; produto interno bruto; desenvolvimento sustentável; valoração ambiental; capital natural. 


\title{
ACCOUNTING FOR SOIL EROSION: AN ENVIRONMENTAL ADJUSTMENT FOR THE STATE OF SÃO PAULO AGRICULTURAL GROSS PRODUCT
}

\author{
Author: GUILHERME SORIA BASTOS FILHO \\ Adviser: Prof. Dr. RICARDO SHIROTA
}

\section{SUMMARY}

This is an economic valuation of the environment, related to the depreciation of the soil resource by erosion. The study covers the period between 1980 and 1991, a twelve-year period of instability in the Brazilian economy. Surprisingly, the agricultural sector had a marked growth in that period, presenting a sharp contrast from the economy as a whole. There are strong evidences that in these years the soil resources had been under high pressure. The State of São Paulo was chosen because of its importance in the national economy, and also due to availability of data.

The traditional economic indicators of wealth and income certainly leaves off the accounting of natural capital losses, thus masking the real wealth of a country. Often, these losses are the result of unsustainable growth rates of economies, which leads to a false impression of GDP's growth. This is one of the reasons such losses should be valuated and discounted from the usual wealth and the income indicators.

In this study, the additional costs incurred by the agricultural sector of the State of São Paulo due to soil erosion and represented by nutrient losses (nitrogen, 
phosphorus, potash, calcium and magnesium) will be accounted for a twelve-year period and discounted from the State's Agricultural Gross Domestic Product. The annual average value of soil depreciation was estimated in US\$ 176 millions. The inexistence of a widely accepted methodology to calculate the Net Domestic Product (NDP) forced an environmental adjustment on the Gross Domestic Product (GDP), which is the most commonly used indicator in macroeconomic analysis. During the twelve year-period, soil depreciation represented up to $5,23 \%$ of the State's Agricultural Gross Domestic Product.

key-words: environmental accounting; soil erosion; gross domestic product; sustainable development; environmental valuation; natural capital. 


\section{INTRODUÇÃO}

Entre 1980 e 1991, o setor agropecuário brasileiro apresentou um excelente desempenho frente ao crescimento da economia como um todo. A produção física do setor (medida pelo produto real), durante esse período, aumentou $31,57 \%$, contra apenas $16,94 \%$ verificado na economia.

No entanto, as medidas de desempenho econômico obtidas através do sistema de contabilidade social vigente no Brasil não levaram em conta a degradação do meio ambiente. Devido à situação conjuntural da época, é possível que, sob o aspecto ambiental, o crescimento do setor neste periodo não se tenha dado de forma sustentável, agravando desta forma as pressões que a base dos recursos naturais já vinha sofrendo e gerando elevados custos ambientais para a sociedade (evidências dessa pressuposição serão abordadas na revisão de literatura).

O conceito de desenvolvimento sustentável se insere justamente neste paradoxo existente entre o crescimento econômico e a preservação do meio ambiente. 0 grande desafio reside em garantir que as atividades econômicas continuem provendo a sociedade de beneficios pelo periodo de tempo mais longo possível, servindo às atuais e futuras gerações ${ }^{1}$.

${ }^{1}$ Em termos conceituais. segundo Relatório da Comissão Mundial Sobre o Meio Ambiente e o Desenvolvimento. de 1987 (MUELLER, 1991, p.2), o desenvolvimento "para ser sustentável, deve 
Assim como em âmbito nacional, o setor agropecuário do Estado de São Paulo apresentou um excelente desempenho, tendo sua produção fisica crescido $31,71 \%$ entre 1980 e 1991 . Um crescimento que, sob o aspecto da sustentabilidade, foi notadamente frágil. A agricultura paulista é intensa na utilização de insumos modernos e maquinário pesado. As monoculturas de cana e laranja durante o periodo se estenderam por vastas áreas, implicando uma considerável perda de biodiversidade e conseqüente vulnerabilidade ao ataque de pragas e doenças. A devastação da cobertura vegetal original continua sendo um grave problema que acaba por contribuir diretamente à intensidade da erosão e à perda da biodiversidade. Segundo estimativas de BELLINAZZI JUNIOR et al. (1981), 80\% da área cultivada no Estado de São Paulo vêm sendo afetados pela erosão acima do limite de tolerância dos solos.

O esforço de se incluírem aspectos ambientais no cálculo desses indicadores, como por exemplo do Produto Interno Bruto (PIB), seria uma forma de se buscarem soluções econômicas atreladas à sustentabilidade do desenvolvimento. A interpretação desses indicadores assumiria uma outra dimensão, extrapolando a análise dos resultados apenas sob o enfoque puramente econômico, passando a considerar que acréscimos ou reduções nos valores dos produtos brutos tenham alguma relação com a base de recursos naturais do local.

Metodologias vêm sendo testadas em diversos países, de acordo com a disponibilidade de informações econômicas e ambientais, numa tentativa de incluir o ambiente como variável importante nas relações econômicas de cada sociedade das necessidades das gerações futuras". 
(REPETTO et al., 1989; SOLÓRZANO et al., 1991; VAN TONGEREN et al., 1991).

Nesta dissertação será ajustada ambientalmente uma série de doze anos do PIB agropecuário paulista, em função da degradação do solo. O valor da depreciação deste recurso será obtido a partir da determinação dos custos de reposição dos nutrientes que uma das principais externalidades da atividade agropecuária, a erosão do solo, gera sobre as unidades agrícolas. 


\section{REVISÃO DE LITERATURA}

Esta revisão divide-se em quatro partes. A primeira consiste na descrição dos antecedentes históricos do problema ambiental em questão, que é a erosão do solo. O problema é tratado inicialmente no contexto do desenvolvimento do setor agropecuário, observado na década de setenta, quando uma combinação de política de crédito rural subsidiado e de extensão rural acelerarou a adoção no país de pacotes tecnológicos preconizados pela Revolução Verde. Em seguida, passa-se a uma análise da conjuntura macroeconômica do período estudado (década de oitenta e os dois primeiros anos da década de noventa), destacando o excelente desempenho do setor agropecuário. Tradicionalmente, o crescimento do setor ao longo da década de oitenta é explicado com base na capacitação tecnológica da agricultura ocorrida na década anterior. Entretanto, a partir desse mesmo ponto é que as evidências das pressões existentes sobre os recursos naturais, especificamente sobre o solo, são levantadas. Na segunda parte, aborda-se a questão da necessidade de mudança dos padrões clássicos da análise econômica, mostrando como a teoria neoclássica vem procurando ampliar seus conceitos com o intuito de aperfeiçoar o mecanismo de alocação dos recursos no mercado, através da sinalização via preços. A discussão avança, na terceira parte, com as implicações das 
falhas da teoria econômica com relação aos recursos naturais sobre o Sistema de Contas Nacionais e seu principal indicador, o Produto Interno Bruto (PIB). A literatura existente mostra que esforços vêm sendo despendidos na área da pesquisa econômica com vistas a transformar o PIB em um indicador mais consistente com o conceito de desenvolvimento sustentável. Finalmente, na quarta parte é descrito o fenômeno da erosão agrícola do solo, seus impactos e mensurações, ressaltando a sua importância como uma das mais preocupantes fontes de poluição agrícola no Estado de São Paulo, devido à abrangência de suas externalidades.

\subsection{A agricultura brasileira e paulista: da Revolução Verde ao período em estudo, 1980-91.}

No Brasil, ao fim da década de sessenta e ao longo da década de setenta, iniciou-se o processo de "modernização" da agricultura brasileira. O governo federal teve um importante papel nesse processo, pela promoção dos serviços de extensão rural (sistema EMBRATER - Empresa Brasileira de Assistência Técnica e Extensão Rural), da pesquisa agrícola (sistema EMBRAPA² - Empresa Brasileira de Pesquisa Agropecuária, criada em 1973) e pelas políticas de crédito subsidiado para aquisição de maquinário agrícola, sementes melhoradas e insumos quimicos. Este marco na história da

2 Segundo RIBEIRO $(1979$, p.16), citado por SILVA (1995), as ações dos centros de pesquisa da EMBRAPA possuiam linhas de pesquisa que "objetivavam criar tecnologias de caráter químicobiológico. capazes de propiciar aumento da produtividade da terra e do trabalho. A idéia geral de organização da pesquisa é a de selecionar procedimentos e técnicas, com 0 intuito de solucionar problemas de dimensão nacional, de modo a possibilitar que os diversos Centros possam adaptar os seus resultados. tendo-se em conta as condições locais". 
agricultura brasileira teve sua origem nas idéias disseminadas pela chamada Revolução Verde, na década de sessenta ${ }^{3}$, que tinha como meta resolver o problema da oferta mundial de alimentos e da desigualdade distributiva entre os países.

A Revolução Verde preconizava que a chave para a solução desses grandes problemas mundiais estava no aumento da produtividade agrícola, garantindo uma oferta crescente de alimentos para o mundo e fontes de geração de renda e emprego para os países que dependiam fortemente da agricultura. O pressuposto básico era que "a produtividade cresceria indefinidamente dado que a produção agrícola se encontrava agora inserida num novo contexto tecnológico suportado por pesquisas modernas e desenvolvimento de infra-estrutura" (PIMENTEL \& PIMENTEL, 1991).

No Estado de São Paulo, o estabelecimento da agricultura moderna foi garantido pelas suas pioneiras instituições de pesquisa, como o Instituto Agronômico de Campinas, e de assistência técnica, as Casas da Agricultura. Sua consolidação foi dada graças a um processo de urbanização e industrialização generalizado por todo o interior paulista, no início da década de setenta, tendo como foco de irradiação a região metropolitana, firmando a relação entre a agricultura e o setor industrial (provedor dos insumos modernos).

Este processo de modernização pelo qual passou a agricultura brasileira ao longo da década de setenta, foi sem dúvida um dos grandes motivos por que o setor

\footnotetext{
3 AMSTALDEN (1991) faz diversas considerações críticas ao modelo de desenvolvimento agrícola implementado ao longo das décadas de sessenta e de setenta, que relevam não somente os impactos ambientais, mas os sócio-econômicos e políticos também. Para ele, o modelo de modernização levou o país a uma situação de dependência tecnológica, que pode ser facilmente constatada pelo domínio de grandes multinacionais no setor de insumos modernos da agricultura: máquinas, sementes e produtos químicos em geral.
} 
conseguiu suplantar a crise recessiva que se abateu sobre a economia na década seguinte. Ainda, o crescimento econômico do país vinha sendo promovido graças a um endividamento interno e externo sem precedentes, acompanhado por um desequilibrio nas contas públicas, devido, em grande parte, à forte presença do Estado na economia. O governo concedia estímulos a diversos setores, através de crédito subsidiado, incentivos fiscais, além de fornecer bens e serviços públicos a preços reduzidos (SILVA, 1991, p. 6-7).

De 1968 a 1973, o Brasil viveu um período de acelerado crescimento econômico, caracterizado como o "milagre econômico". De 1974 a 1979, a economia continuou crescendo, embora a taxas mais discretas. A partir de 1980 , uma conjunção de fatores internos e externos dá início a um dos períodos mais críticos da economia brasileira, a década de oitenta, conhecida também como a "década perdida"4, e que se estende por mais dois anos na década de noventa. As crises no Oriente Médio (afetando o preço do petróleo), a redução dos fluxos de investimentos estrangeiros, a elevação das taxas de juros internacionais e nacionais, o crescimento da dívida interna e externa, além da ascensão inflacionária levaram o governo a adotar uma diferente estratégia da que até então vinha praticando.

A economia começou, a partir desse ponto, a passar por uma série de profundos ajustes, dentre os quais a contenção nos gastos públicos através de cortes nos diversos incentivos econômicos e fiscais utilizados largamente na década de setenta.

O reflexo destes cortes se fez sentir por toda a economia. O Produto Interno Bruto Brasileiro (a custo de fatores), em 1983, caiu 8,1\% em relação aos níveis

\footnotetext{
${ }^{4}$ O PIB per capita de 1989 foi apenas 1,97\% superior, em termos reais, em relação ao de 1980.
} 
de 1980. Neste mesmo período, o PIB do setor industrial nacional foi quase $15 \%$ menor, enquanto, no setor de serviços, a queda foi de cerca de $2 \%$. A taxa de investimento, relação entre formação bruta de capital fixo e o PIB, reduziu-se de $21 \%$ em 1981 para 16\%, em 1990 (SILVA, 1991, p.5).

Para o setor agropecuário, no entanto, analisando-o em termos de produto físico, não houve uma "década perdida", e sim um período de dez anos durante o qual o desempenho do setor foi notável. Até 1983, em termos de produto real, o setor havia crescido $6,82 \%$, com relação a 1980 ; ao final de 1989 , o crescimento acumulado foi de $33,17 \%$, contra os $21,16 \%$ verificados em toda a economia. No caso do Estado de São Paulo, a produção fisica do setor agropecuário cresceu, durante a década de oitenta, $22,01 \%$, contra apenas $12,66 \%$ da economia paulista ${ }^{5}$ (ver figura 1 e apêndices 1 a-e). Para o dois primeiros anos da década de noventa, a economia entrou em uma nova fase recessiva, apresentando fortes quedas nos produtos reais nacional e paulista de $9,9 \%$ e $5,7 \%$, respectivamente em relação aos niveis observados em 1989. Os setores agropecuários, por sua vez, continuaram se destacando, caindo apenas $1,2 \%$ em nível nacional e crescendo 7,4\% no Estado de São Paulo.

Vale ressaltar que o setor agropecuário cresceu mesmo diante de ajustes extremamente fortes. Embora as taxas reais de juros do crédito rural tenham-se mantido negativas ao longo da primeira metade da década de oitenta (GOLDIN \& REZENDE, 1993, p.22), o volume de recursos de crédito para comercialização, custeio e

\footnotetext{
${ }^{\varsigma}$ Quando se analisa o Produto Interno do Setor, esse desempenho fica bem mais discreto uma vez que esta variável macrocconômica contabiliza também a evolução dos preços, que por sinal foram vertiginosamente decrescentes ao longo deste período (MONTEIRO, 1993, p. 73).
} 


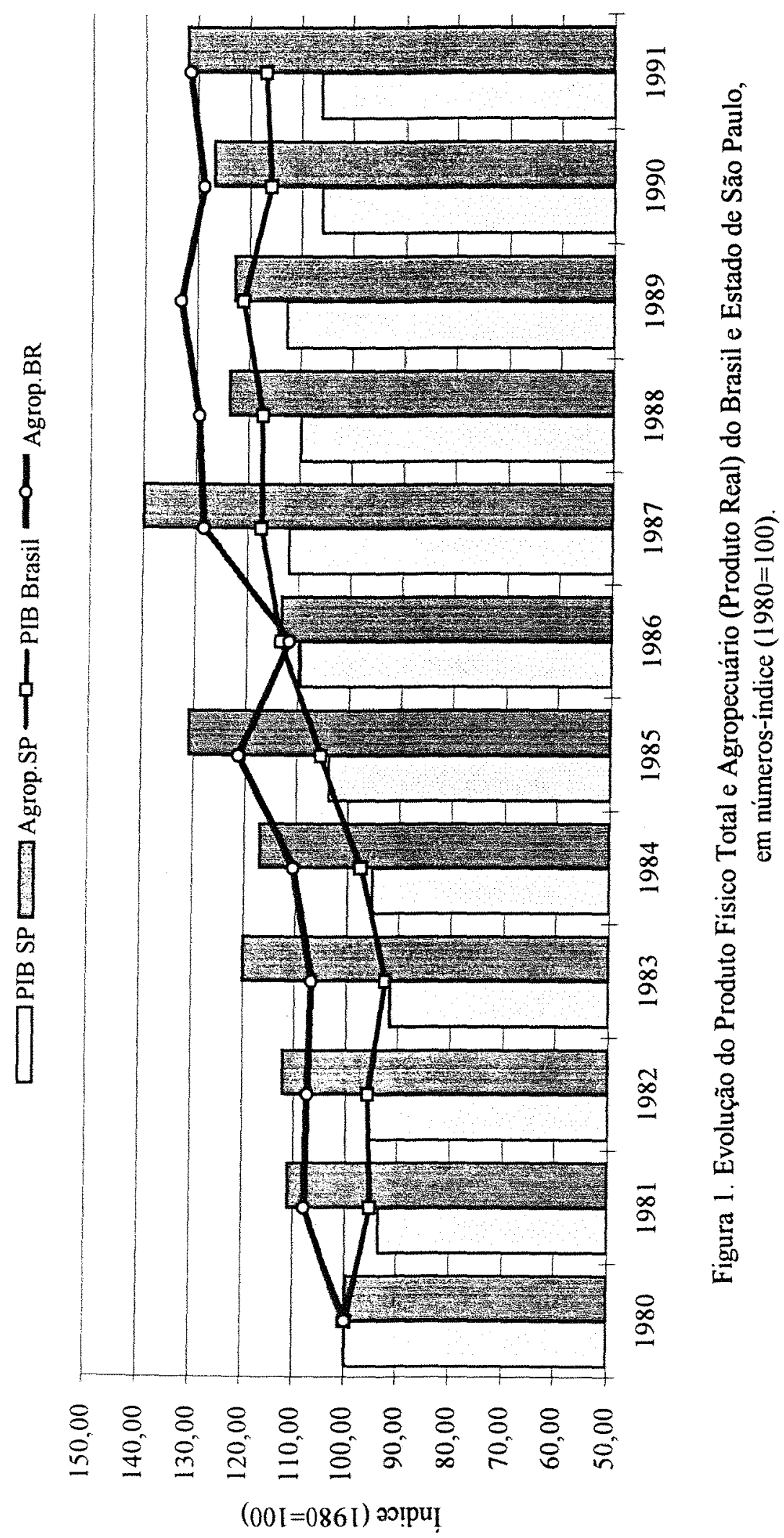


investimentos na agricultura foi drasticamente reduzido. Com relação aos níveis de 1980, houve um corte de mais de $60 \%$ dos recursos em 1985; e em 1991, o montante disponivel não chegou aos $25 \%$ do volume concedido em 1980 . Mesmo assim, safras recordes de grãos foram registradas no periodo, evidenciando a rapidez com que o setor se adaptou frente ao cenário macroeconômico extremamente desfavorável.

A participação do setor agropecuário em relação ao PIB brasileiro, no entanto, caiu de $24,9 \%$ em 1949 , para próximo de $11 \%$ nas décadas de setenta e oitenta (LEWHING 1993, p.61-63). Esta é uma tendência explicada pela Lei da Importância Relativa Decrescente da Agricultura, abordada na literatura existente sobre a teoria do desenvolvimento econômico e agricultura. O setor agrícola se moderniza, adquire os insumos do setor industrial, gera um excedente de produção, e oferta alimentos a preços mais baixos para o setor urbano-industrial. Assim, este setor se desenvolve, impulsionado pela apropriação do chamado excedente agricola (NICHOLLS, 1975).

Ao longo da década de oitenta, o aumento da oferta dos produtos do setor agropecuário se deu num período em que a demanda se encontrava estagnada, o que resultou no declínio dos preços no mercado interno (GOLDIN \& REZENDE, 1993, p.62). Ainda com a economia em recessão, os preços agrícolas continuaram caindo nos dois primeiros anos da década de noventa. O nível dos preços do setor, em 1991, chegou a representar apenas $60 \%$ do valor de 1980 (ver apêndice 2). A queda da renda agrícola bruta é uma decorrência direta deste fato (DAVID, 1991, p.373).

Segundo GOLDIN \& REZENDE (1993), a sustentação do produto agropecuário, ao longo da década de oitenta, foi proporcionada pelas baixas 
elasticidades-preço de oferta dos fatores primários (terra e mão-de-obra), conseqüentemente pela flexibilidade dos preços dos respectivos fatores e pela tendência da plena utilização do estoque de capital existente na agricultura nas fases recessivas. Nestas fases, a utilização da mão-de-obra familiar implica menores dispêndios para o produtor, uma vez que normalmente não há remuneração direta para esse tipo de mão-de-obra. Ademais, o custo de oportunidade dessa força de trabalho decai drasticamente, já que a possibilidade de se conseguir um emprego urbano diminui bastante em função da recessão. No caso da terra agrícola, por não ter um uso alternativo fora da agricultura, seu custo é determinado de forma residual, ou seja, não onera a produção agrícola. Assim sendo, a flexibilidade nos preços da mão-de-obra na agricultura e a do preço da terra, ao acompanharem o movimento dos preços dos produtos agrícolas, contribuem para a desoneração da produção agrícola em circunstâncias econômicas adversas, como é o caso de um período recessivo, sem crédito disponível.

Com relação ao crescimento verificado no setor, a política econômica exerceu importante papel tanto em relação aos produtos exportáveis quanto aos de consumo doméstico. Para os primeiros, o realinhamento da taxa de câmbio foi essencial para que as exportações agrícolas mantivessem competitividade frente à queda dos preços agrícolas internacionais. A média da taxa de câmbio de paridade entre 1980 e 1991 foi $6,4 \%$ superior à média da década de setenta, embora tenha havido fortes oscilações ao longo desses doze anos (GOLDIN \& REZENDE, 1993, p. 61).

No caso do mercado doméstico, a política de garantia de preços mínimos representou, em si, uma redução de risco do setor, incentivando o cultivo das 
culturas por ela contempladas e compensando os efeitos negativos que a política de desvalorização cambial poderia ter sobre a produção de culturas voltadas ao mercado interno.

Além das políticas, as inovações tecnológicas que ocorreram no setor também explicam o destacado desempenho da agricultura. Os ganhos de produtividade ao longo do período estudado foram consideráveis. Segundo MONTEIRO (1993), a expansão da área cultivada de 1980 a 1991, no Brasil, foi de apenas $1 \%$, enquanto o produto real do setor, como já citado, chegou a ser $31,57 \%$ superior ao nível observado em 1980. Quanto ao Estado de São Paulo, o crescimento da área cultivada (considerando as áreas de pastagens e de reflorestamentos) foi menor ainda, 0,43\%, enquanto o produto fisico chegou a crescer $32,01 \%$ em relação a 1980 .

A partir dessa breve análise sobre o desempenho do setor agropecuário, alguns pontos que explicam o seu sucesso geram também questionamentos acerca da sustentabilidade desse notável crescimento. Não é o objetivo deste estudo analisar empiricamente a pressão exercida sobre a base de recursos naturais durante os períodos recessivos da economia, entretanto algumas evidências teóricas colaboram para afirmar que esta pressão existe e que deve ser significativa:

i. GOLDIN \& REZENDE (1993, p.66) citam, por exemplo, que em épocas recessivas há uma tendência, de curto prazo, verificada no setor agropecuário de utilizar plenamente o seu estoque de capital, dentre eles a terra. O solo agrícola, por não possuir uso alternativo fora da agricultura, será utilizado sempre que uma renda 
positiva, mesmo que mínima, for gerada ${ }^{6}$. Os cortes de custos serão feitos justamente sobre aquelas operações que, num curto prazo de tempo, menos interferirem na produção. Os retornos econômicos das práticas conservacionistas, por exemplo, não possuem resultados imediatos, ou que sejam percebidos imediatamente pelos agentes econômicos, portanto seriam operações que facilmente deixariam de ser adotadas;

ii. a instabilidade macroeconômica gera fortes distorções na alocação de recursos de uma economia, uma vez que frente a um ambiente de incertezas (com elevadas taxas inflacionárias e de juros) o consumo presente é favorecido em detrimento do consumo futuro (CAIRNCROSS, 1992, p.49). A nível micro, esta instabilidade acaba gerando sérios problemas ambientais. Em períodos de preços elevados, os produtores são estimulados a utilizar a base de recursos naturais acima de sua capacidade de suporte para maximizar o seu fluxo de renda no prazo mais curto. Por outro lado, quando os preços encontram-se deprimidos, o estoque de recursos é desvalorizado e a sua conservação é desestimulada (CUNHA et al., 1993, p.49); e,

iii. ainda, em ciclos recessivos da economia, apesar de a demanda do setor por investimentos em bens de capital e insumos cair, o que refletiria diretamente na queda dos rendimentos fisicos das culturas, o nivel do produto agrícola poderia ser mantido compensando a queda da produtividade pelo emprego mais intenso de mão-de-obra. Ou seja, o uso de agrotóxicos, como no caso de herbicidas, poderia ser substituído por

\footnotetext{
${ }^{6}$ Segundo CUNHA et al. (1993, p.45), esta situação na pecuária pode ser observada em periodos de relações de preços desfavoráveis e restrição de crédito. Procura-se maximizar a renda por hectare no curto prazo. sem levar em consideração a sustentabilidade da geração desta renda. Desta forma, no caso das pastagens, a sua utilização acima da capacidade de suporte, acaba levando a uma situação de deficiente cobertura e conseqüente intensificação do processo erosivo.
} 
um maior emprego de mão-de-obra (GOLDIN \& REZENDE, 1993; nota de rodapé nº 4, p.67)

Observando-se o início da década de oitenta, constata-se a drástica redução no índice de consumo aparente destes insumos, como reflexo direto dos cortes governamentais sobre o crédito agrícola, enquanto a proporção do emprego agrícola, com relação ao emprego total, manteve-se praticamente constante (ver tabela 1). Proporcionalmente à queda observada no consumo aparente dos insumos, a manutenção dos niveis de emprego revela uma participação maior da mão-de-obra, corroborando para a afirmação acima.

Para muitos ambientalistas, a menor utilização de produtos químicos, em principio, poderia ser vista como benéfica ao ambiente. Entretanto, a não adequação dos niveis de fertilidade e tratos fitossanitários à exigência da cultura pode gerar, por outro caminho, indesejados impactos ao meio ambiente, decorrentes da má cobertura do solo ${ }^{7}$. Uma cobertura deficiente do solo contribui para a ação erosiva das chuvas, aumentando o problema da degradação ambiental.

Quanto ao Estado de São Paulo, segundo MARTIN et al. (1991, p.4), a mudança de composição da produção em direção a produtos de maior concentração de valor foi resultante do processo de intensificação da agricultura, gerando também uma

\footnotetext{
${ }^{7}$ A princípio poder-se-ia imaginar que a redução na utilização dos insumos modernos fosse decorrente da utilização de variedades menos exigentes, lançadas pelo próprio sistema de pesquisa. No entanto, a preocupação com este uso excessivo de agrotóxicos e fertilizantes só começou a surgir na pesquisa agropecuária $\mathrm{em}$ meados da década oitenta, quando a conscientização ambiental passou a assumir importância em termos nacionais (SILVA, 1995). Para o desenvolvimento de novas variedades vegetais despendem-se cm média oito anos de pesquisa, portanto esta redução do consumo de insumos em função das novas variedades só terá maior impacto a partir do início da década de noventa.
} 
Tabela 1. Índices de consumo aparente de insumos agrícolas selecionados 1975/91 $(1975=100)$ e percentagem do pessoal ocupado na agricultura em relação à população ocupada total - 1976/90.

\begin{tabular}{lcccc}
\hline Anos & Defensivos & Fertilizantes & Tratores & Mão-de-obra \\
\hline 1975 & 100 & 100 & 100 & n.d. \\
1976 & 90 & 128 & 110 & 36.7 \\
1977 & 113 & 162 & 84 & 36.5 \\
1978 & 121 & 163 & 72 & 33.7 \\
1979 & 127 & 180 & 85 & 32.5 \\
1980 & 143 & 212 & 88 & n.d. \\
1981 & 111 & $\mathbf{1 3 9}$ & $\mathbf{4 9}$ & $\mathbf{2 9 . 3}$ \\
$\mathbf{1 9 8 2}$ & $\mathbf{8 4}$ & $\mathbf{1 3 7}$ & $\mathbf{4 3}$ & $\mathbf{2 9 . 5}$ \\
$\mathbf{1 9 8 3}$ & $\mathbf{7 4}$ & $\mathbf{1 2 2}$ & $\mathbf{3 9}$ & $\mathbf{2 7 . 1}$ \\
1984 & 103 & 185 & 72 & 29.8 \\
1985 & 93 & 171 & 71 & 28.5 \\
1986 & 124 & 210 & 80 & 25.9 \\
1987 & 116 & 222 & 69 & 24.6 \\
1988 & 110 & 204 & 53 & 24.2 \\
1989 & 115 & 178 & 47 & 23.2 \\
1990 & 112 & 181 & 38 & 22.8 \\
1991 & 109 & 191 & 31 & n.d. \\
\hline
\end{tabular}

Fonte: IBGE (defensivos e fertilizantes) e ANFAVEA (tratores). Retirado de GOLDIN \& REZENDE (1993, pp.50-51).

Nota: O aumento no consumo aparente dos defensivos e fertilizantes após 1984 deveuse basicamente à queda dos preços reais destes insumos. No caso do maquinário agrícola, a elevação dos preços reais justifica o decréscimo do índice ao final da década de oitenta. 
ocupação desordenada do território (sem observar a aptidão agrícola do solo). As culturas de mercado interno foram deslocadas para áreas menos apropriadas, cedendo espaço para culturas voltadas à exportação (citricultura, principalmente) e à substituição energética (cana-de-açúcar). Esta alteração na ocupação do espaço agrícola paulista somada a problemas fundiários desencadeou uma acelerada degradação dos recursos naturais (MARTIN et al., 1991, p.162).

As regiões que hoje compreendem a Nova Alta Paulista, entre outras do oeste do estado, por exemplo, apresentam solos esgotados e inapropriados para o cultivo agrícola. O cultivo de café cedeu espaço à pastagem extensiva na região. Para que estas áreas sejam aproveitadas, grandes somas necessitam ser investidas, seja sob a forma de investimentos diretos privados, seja por investimentos públicos. A necessidade de vultosos investimentos para recuperar, hoje, a degradação ambiental que ocorreu no passado mostra nitidamente que há falhas no tradicional sistema de contabilidade social. Se fosse possivel resgatar uma série histórica do valor da produção da região da Nova Alta Paulista, observar-se-ia que o aumento do produto regional nos áureos tempos do café não era sustentável, tanto que atualmente esta é uma das regiões mais pobres do estado

Assim como o tradicional exemplo da floresta totalmente devastada gerando acréscimos no produto da economia, a sobreutilização do recurso solo ao longo da década de oitenta também mascarou o real desempenho do setor agropecuário. Ambos exemplos levantam a questão acerca da distorção existente nas tradicionais medidas de desempenho econômico, que mostram crescimentos, ou até níveis estacionários, quando, 
na realidade, a base de recursos naturais está sendo exaurida ou deteriorada, sem ser percebida pelo indicador de renda. O conceito de renda verdadeira, a ser explorado na próxima seção, permitirá entender com maior clareza a distorção existente nos tradicionais indicadores econômicos.

\subsection{A teoria econômica tradicional e a valoração dos recursos naturais}

Normalmente, os bens e serviços transacionados na economia possuem preços. Os preços são considerados sinais do mercado que refletem a escassez relativa desses bens ou serviços e que os orientam para o melhor uso alternativo. A interseção das curvas de oferta e de demanda de um determinado bem ou serviço determina o preço e a quantidade de equilibrio, num mercado livre e competitivo.

Quanto aos bens e serviços fornecidos pela Natureza, muitas vezes considerados como presentes da Natureza, os preços inexistem ou não refletem o real custo de oportunidade do recurso. Conseqüentemente, o recurso "gratuito" é utilizado de uma forma distorcida, acima de sua capacidade assimilativa (por exemplo, despejar poluentes num curso d'água acima da sua capacidade natural de depuração) ou de sua capacidade regenerativa (por exemplo, exploração madeireira).

As explicações para estas distorções começam pela forma como a teoria econômica tradicional aborda os recursos naturais e ambientais ${ }^{8}$. Segundo

\footnotetext{
8 "... o termo recurso é basicamente sinônimo de ativo, entendendo-se por recursos naturais a gama de elementos da natureza que servem como insumos, ou como bens de consumo em alguns casos, para a atividade humana, sendo bens primários e que não foram produzidos anteriormente pela sociedade. Já os recursos ambientais seriam o conjunto de amenidades destinadas basicamente ao consumo e à disposição da coletividade. Incluem-se, nesse item, o ar e a água limpa, a paisagem. o silêncio etc." (ABLAS. 1992. p.101).
} 
LEFTWICH $(1983$, p.5), os recursos na sua maioria são limitados em quantidade, ou seja, são escassos. Até aqui, a definição de recursos naturais e ambientais adequa-se perfeitamente pela limitação dos estoques fisicos dos recursos naturais e pelo limite da capacidade de suporte dos recursos ambientais. Mas, de acordo com a escassez relativa, classificam-se os recursos em livres ou econômicos. Os recursos econômicos, ou escassos, apresentam-se como objetos de estudo pela economia, uma vez que são quantitativamente limitados em relação ao desejo pelos bens que podem produzir. Já os recursos livres são aqueles considerados relativamente abundantes e "que podem ser obtidos pela simples apropriação" (LEFTWICH, 1983, p.5), portanto não possuem preços. Segundo o autor, esses bens não possuem qualquer significado para análise econômica. Os recursos naturais e ambientais são tratados pela teoria econômica tradicional justamente como sendo livres ou gratuitos.

O preço, que simplificadamente serviria como um indicativo de escassez do recurso, no caso dos recursos naturais e ambientais, não "funciona". O problema, como assegura RANDALL $(1987$, p.12), é que nem todo recurso escasso apresenta preço pelo fato de não haver mercados em funcionamento que o comercializem. Isto ocorre com os recursos naturais e ambientais.

A inexistência desses mercados no presente pode comprometer o desenvolvimento das atividades econômicas no futuro, levando muitas espécies animais e vegetais à extinção, minerais à exaustão e o uso do solo, ar e água além do nível máximo de capacidade de suporte. É claro que os avanços tecnológicos amenizam os problemas de escassez do recurso, mas nem sempre são suficientes para evitar que os danos sobre o 
ambiente atinjam o ponto de irreversibilidade ${ }^{9}$. Ao chegar a este ponto, a capacidade que determinado bem ou serviço ambiental teria de gerar utilidades à presente geração ou às gerações futuras fica definitivamente comprometida. Ademais, as inovações tecnológicas, assim como o mercado de uma maneira geral, guiam-se somente pela escassez dos recursos no presente, ou pelo menos num horizonte de tempo relativamente curto. Segundo CUNHA (1992, p. 11) “os recursos naturais têm, em primeiro lugar, de se tornar escassos para que se viabilize economicamente a inovação tecnológica (que inclui, ambas, a geração e a adoção)"'.

Dessa forma, as contribuições da teoria econômica devem avançar, sendo capaz, segundo MARGULIS (1990, p.158), de "avaliar as relações entre oferta e demanda dos diversos recursos, a forma pela qual devem ser 'administrados' de modo a maximizar o bem-estar social e quais as taxas de exploração e quais as políticas de preços que garantam esta maximização".

Deve-se enfatizar, entretanto, que esta maximização de bem-estar no que se refere aos recursos naturais e ambientais nem sempre atinge o ponto ótimo de Pareto. Em geral, a alocação desse tipo de recurso não é determinada pelo mercado e, portanto, as soluções encontradas nem sempre são ótimas, mas do tipo second best.

A inadequação do sistema de preços em antecipar a escassez futura dos recursos naturais e ambientais é decorrente do que se chama, segundo RANDALL (1987, p. 164), de imperfeição ou falha de mercado (market failure). Segundo o autor, as falhas de mercado podem ser explicadas pela característica do bem ou serviço ambiental e pelo

\footnotetext{
${ }^{9}$ FISHER (1981, pp.129-163) destina uma seção de seu livro ao problema da irreversibilidade nos processos ambientais. ao menos no horizonte de tempo do homem.
} 
20.

grau de atenuação dos seus direitos de propriedade. Assim sendo, os bens podem ser classificados como não passiveis de exclusão, não rivais e congestionáveis ${ }^{10}$.

Essas imperfeições do mercado, além de comprometerem a utilização dos recursos acima da capacidade de suporte ou regenerativa, acabam influenciando, direta ou indiretamente, a atividade de um outro indivíduo. Essa redução observada na função de utilidade ou de produção do indivíduo, ou agente econômico é o que se entende por externalidade negativa. Intuitivamente, esta só existe, ou é relevante, quando efetivamente sentida pelas partes afetadas; caso contrário não existe externalidade. RANDALL (1987, p. 184) define, economicamente, as externalidades como sendo "simplesmente manifestações de uma determinação ineficiente de preços". Diz-se que uma externalidade é Pareto-relevante somente quando a sua solução implicar um aumento de utilidade para todas as partes envolvidas. Essa solução será eficiente apenas quando o preço correto for atribuido ao uso do recurso em questão.

Esse é o problema, uma vez que a grande dificuldade reside justamente na determinação do valor econômico do bem ou serviço ambiental utilizado. A valoração econômica envolve conceitos subjetivos de bem-estar, de dificil mensuração, e que nem sempre apresentam metodologias já definidas e testadas para serem aplicadas.

Segundo PEARCE \& TURNER (1990, p.131), o valor econômico total

\footnotetext{
${ }^{10}$ Um bem não-exclusivel é aquele que uma vez disponível, pode ser utilizado por qualquer pessoa. Um bom exemplo são as ondas de rádio. Uma vez transmitidas, qualquer pessoa que possua um sintonizador, um rádio, poderá usufruir as informações contidas nas ondas. Um bem é considerado não-rival quando a sua quantidade total está disponível simultaneamente a todos os indivíduos, sem que o consumo de um diminua a quantidade disponível para os outros. Já os bens congestionáveis podem ser considerados um caso especial de não-rivalidade. A caracteristica da não-rivalidade deixa de existir a partir do momento em que se adiciona mais um consumidor, e a utilidade dos demais se reduz. Como exemplo, RANDALL (1987, p.177) cita exemplos de campings, mirantes, trilhas de caminhada, áreas de caça e locais de velejo e pesca.
} 
do meio ambiente é resultante de três parcelas: valor de uso, valor de opção e valor de existência. A primeira parcela representa o valor atribuido pelas pessoas que efetivamente utilizam o recurso ambiental ou natural. Por exemplo, os pescadores, os madeireiros e os agricultores, que utilizam o pescado, a madeira e o solo como fonte de geração de renda. Ainda, as pessoas que utilizam o meio ambiente como fonte de lazer e de contemplação. A segunda parcela relaciona-se com o uso futuro, independentemente de a pessoa usar o recurso no presente ou não. É a utilidade que uma pessoa obtém ao contribuir para a preservação do meio ambiente para o seu consumo futuro ou para o consumo de suas gerações futuras. A terceira representa o valor do recurso independentemente de sua utilização ou não. Seria a utilidade que uma pessoa obtém ao contribuir, por exemplo, para uma determinada organização ambiental que cuida da preservação do urso polar no Ártico, mesmo sabendo que dificilmente um dia usufruirá de um passeio ao pólo, onde desfrutaria um prazer por ver o urso em seu habitat natural.

A segunda e a terceira parcelas, ambas com elevado grau de subjetividade em seus conceitos, podem ser quantificadas segundo técnicas que estimulam a revelação das preferências dos indivíduos com relação a determinado bem ou recurso. Estas técnicas são baseadas na simulação de situações e realizadas através de entrevistas procurando captar através de valores monetários a Disposição a Pagar (WTP, do inglês Willingness To Pay) ou a Disposição a Receber (WTA, do inglês Willingness To Accept) do entrevistado pelo item objeto de pesquisa. Porém, a utilização deste referencial metodológico possui limitações tanto no campo teórico quanto no prático, como, por exemplo, a inconsistência dos valores revelados pela amostra populacional 
entrevistada ao longo do tempo, a distorção na resposta esperando levar vantagem com relação aos outros entrevistados ${ }^{11}$, miopia dos consumidores, impactos viesados de acordo com a distribuição de renda, além do que se conhece em psicologia por dissonância cognitiva, que é o fato de as pessoas encararem diferentemente os ganhos das perdas (PEARCE \& TURNER, 1990, p.128; MOTTA, 1990, p.125; BARTELMUS, 1994, p. 164).

Para contornar esses problemas metodológicos, de ordem empírica e teórica, uma alternativa, que vem sendo utilizada nos trabalhos desenvolvidos em diversas partes do mundo, é a de restringir o valor econômico do recurso à mensuração dos impactos que a sobreutilização do recurso em questão tem sobre as atividades econômicas, ou seja, expressando-o em termos de custos de exaustão e de degradação (MOTTA, 1990, p.123).

Mesmo com tantas limitações metodológicas, as motivações para se chegar a um preço de um bem ou recurso do meio ambiente vão muito mais além do que a obtenção de um simples número. Segundo PEARCE \& TURNER (1990, p.124), um uso distinto para as medidas de valor econômico é demonstrar a importância da política ambiental, além de servir como um parâmetro para a racionalidade econômica de se investir na melhoria ambiental. Da mesma forma, FONSECA $(1992$, p.35) considera que as tentativas de avaliação econômica são feitas com os seguintes objetivos:

i. para a tomada de decisões particulares com respeito a projetos de investimento públi-

${ }^{11}$ É o que. em literatura. comumente se conhece como "free-rider effect". 
co e privado ou medidas de política econômica (a avaliação econômica retornaria valores mais precisos sobre os custos e beneficios de determinados projetos ou medidas); e,

ii. para integrar variáveis ambientais aos grandes agregados macroeconômicos presentes no Sistema de Contas Nacionais (SCN). Estes agregados fornecem um sistema de dados sobre as atividades econômicas, além de servirem como parâmetros para a elaboração de políticas econômicas e de planejamento setorial.

Trabalhos como os de MENCK (1993) e de VELOZ et al. (1985), que tratam de avaliações econômicas do controle da erosão em microbacias hidrográficas, atendem ao primeiro objetivo. Já o presente trabalho possui como meta o segundo objetivo, ou seja, ajustar ambientalmente um importante agregado macroeconômico, o PIB

A inclusão de variáveis ambientais no $\mathrm{SCN}$ é um dos desafios que a Organização das Nações Unidas (ONU) vem enfrentando desde o início da década de oitenta (LUTZ \& SERAFY, 1992, p.88), de forma que este sistema contábil possa representar mais precisamente o que John Hicks define como sendo renda: "o objetivo dos cálculos de renda no dia a dia é dar às pessoas uma indicação do quanto podem consumir sem se empobrecerem".

Este tradicional conceito hicksiano é o que se entende por renda sustentável $^{12}$. Segundo DALY (1992, p.8), o termo renda sustentável pode ser considerado uma

\footnotetext{
12 Falar em renda verdadeira. ou sustentável, é o mesmo que se falar em produto sustentável. A identidade PRODUTO = RENDA advém da caracterização de renda como sendo a remuneração dos fatores. pelo pagamento de salários, juros, lucros, aluguéis, impostos e rendas ao exterior. Esses itens nada mais representam que a adição de valores em cada etapa da produção, ou seja o valor adicionado. $O$
} 
redundância, uma vez que a característica central do conceito de renda refere-se à própria idéia de sustentabilidade.

No entanto, da forma como um dos principais indicadores de riqueza de uma nação, o Produto Interno Bruto (PIB), é calculado, esta noção do quanto determinada nação pode consumir é distorcida por não haver valoração apropriada dos recursos naturais e ambientais. É necessária, dessa forma, uma revisão na estrutura de seus cálculos para que os padrões de consumo dessa sociedade se ajustem ao verdadeiro, e sustentável, valor do montante que podem consumir sem se empobrecerem.

Sob este enfoque, MOTTA \& MAY (1994, p.179) definem renda sustentável como "aquela medida de renda que incorpora a dimensão intertemporal do uso do meio ambiente, a qual pode ser entendida como o custo de uso devido ao esgotamento de um recurso finito e também sua dimensão intratemporal que reflete o decréscimo corrente do nível de utilidade ou de produção dos agentes econômicos devido às externalidades geradas pela degradação ambiental".

\subsection{Contas nacionais e meio ambiente}

Desde o início da década de quarenta, a ONU adotou o Sistema de Contas Nacionais $(\mathrm{SCN})$, um sistema estatístico elaborado por Simon Kuznets, cujo objetivo principal é a obtenção de indicadores de desempenho da economia (MOLDAU, 1992, p.77). A ONU desde então vem trabalhando no sentido de definir um modelo conceitual padronizado de contabilidade nacional de forma a permitir a comparabilidade 
das informações entre os países, bem como a divulgação das estatísticas sociais (FIBGE, 1988, p. 11).

Adotados por muitos paises, os agregados macroeconômicos do $\mathrm{SCN}$, como o PIB $^{13}$ e a Renda Nacional, passaram a ser tão difundidos que começaram a ser utilizados erroneamente como indicadores de bem-estar ${ }^{14}$. EL SERAFY \& LUTZ (1992, p.1) afirmam que o conceito de bem-estar (welfare) possui um sentido bem mais amplo que uma simples medida monetária de renda, cobrindo diversos aspectos subjetivos que, muitas vezes, não são valoráveis monetariamente nem estão restritos ao espaço econômico em que ocorrem as transações de mercado.

É neste sentido que surgem algumas correntes de economistas, a favor ou contra o aperfeiçoamento do SCN. Alguns reconhecem os defeitos do SCN, mas acreditam numa reforma, e outros não vêem nem a possibilidade do sistema ser melhorado (MUELLER, 1991, p.7).

Naredo $(1987)^{15}$, citado por MUELLER (1991), representa a primeira corrente. Reconhece o reducionismo, ou a miopia econômica, que o presente SCN sofre ao registrar somente uma pequena parte de um universo constituído por elementos que

\footnotetext{
${ }^{13}$ O Produto Interno Bruto (PIB, ou no inglês, GNP) é o indicador de renda agregada mais comum e utilizado no mundo (EL SERAFY \& LUTZ, 1992). Ele expressa a produção de bens e serviços finais de uma limitada área geográfica (país, estado, bloco de países, ...) durante um certo período de tempo (anual, trimestral, ...).

${ }^{14}$ Índices alternativos foram propostos para que se chegasse a um índice mais consistente de mensuração do bem-estar: o Índice de Desenvolvimento Humano (IDH), das Nações Unidas (FONSECA, 1992, p.34), o índice da OEA e de Benett (ARAÚJO, 1975, p.89) e a Medida Econômica do Bem-Estar (MEW "Measure of Economic Welfare", por NORDHAUS \& TOBIN (1972)). Mesmo com as limitações apontadas por DENISON (1971), com relação à transformação do PIB em indicador de bem-estar, a sua popular utilização. em parte, justifica a tentativa de consolidar um PIB Ambiental.

${ }^{15}$ NAREDO, J.M. Qué pueden hacer los economistas para ocuparse de los recursos naturales? Desde el sistema económico hacia la economía de los sistemas. Madrid. Pensamiento Iberoamericano, n. 12 , jul./dez., p.61-74. 1987.
} 
interferem nas atividades econômicas captadas(ver figura 2). Entretanto nem sempre todos elementos podem ser convencionalmente analisados pela teoria econômica. Segundo Naredo, apenas o universo (U) dos elementos disponíveis para uso (d), apropriados (a) e valorados (v), e que são produziveis (Udavp), é captado pelo SCN; ignoram-se, assim, as inter-relações entre o menor dos subconjuntos e o todo restante, como, por exemplo, o efeito das externalidades negativas que são geradas pelas atividades produtivas. $\mathrm{O}$ aprimoramento do $\mathrm{SCN}$ poderia, desta forma, considerar pelo menos os aspectos mais relevantes dessas inter-relações.

Em outra linha, Richard Norgaard ${ }^{16}$ (citado por MUELLER, 1991, p.12), com uma visão mais radical, afirma que o SCN possui problemas teóricos básicos que inviabilizariam a tentativa de corrigi-lo na direção de incorporar outras dimensões em sua estrutura. O SCN teria evoluído de duas teorias, que a priori seriam inconsistentes, a macroeconômica e a microeconômica. "Então, o Sistema de Contas Nacionais é baseado em convenções estabelecidas através de um processo de consenso adquirido, ao invés de ser baseado em procedimentos deduzidos da teoria econômica" (NORGAARD, 1992, p.55).

Outra crítica levantada diz respeito à necessidade de determinação de valores que, muitas vezes, são incomensuráveis, como o trabalho das donas de casa e o próprio capital natural, ou que seriam inconsistentemente tratados como acréscimo de produto. Por exemplo, quando a pequena propriedade familiar deixa de produzir seu

\footnotetext{
${ }^{16}$ NORGAARD, Richard B. Three dilemas of environmental accounting. Versão preliminar a ser publicada em Ecological Economics. Berkeley, University of California, 1985 (mimeo).
} 

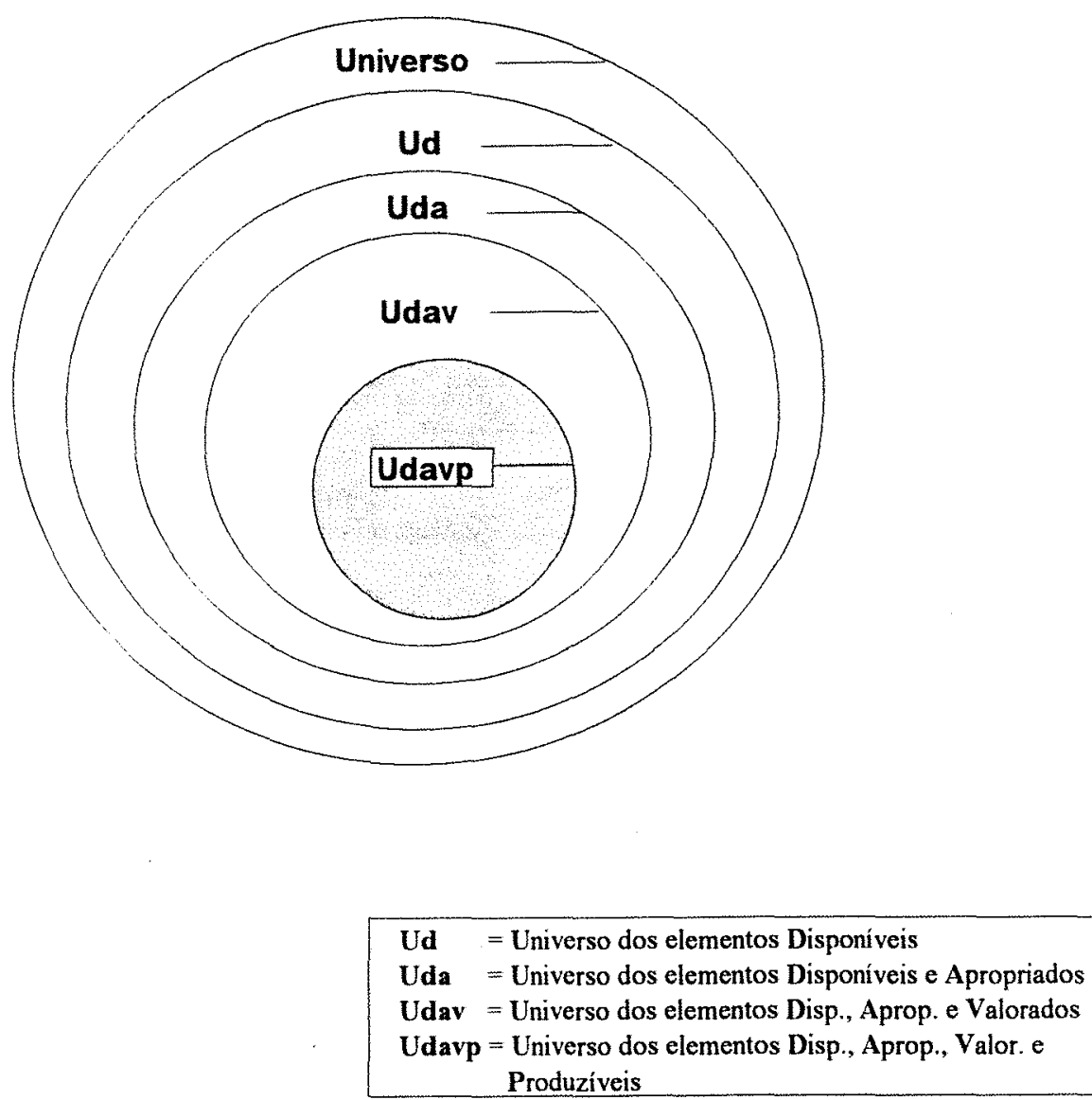

Fonte: MUELLER (1991), retirado de J. Naredo "Que pueden hacer los economistas para ocuparse de los recursos naturales? Desde el sistema económico hacia la economia de los sistemas".

Figura 2. O sistema econômico, seus subconjuntos e o sistema de contas nacionais. 
próprio alimento e contrata mão-de-obra; ou quando a dona de casa entra no mercado de trabalho e para isso contrata uma empregada doméstica e uma babá; ou quando, após uma guerra, residências e fábricas são reconstruídas; ou, finalmente, quando o governo inicia ações corretivas para o ambiente deteriorado (NORGAARD, 1992, p.55).

Ainda, para que a inclusão dos elementos ambientais pudesse ser feita no SCN, seria necessário um profundo conhecimento sobre as relações existentes entre meio ambiente e sistema econômico. Norgaard, portanto, sugere o abandono do SCN e a criação de indicadores de outra natureza que permitam melhor avaliar as relações entre a economia e o meio ambiente (MUELLER, 1991, p.14).

Embora de fato existam problemas metodológicos sérios, o $\mathrm{SCN}$ é amplamente utilizado e não há sistema que possa substituí-lo de imediato. Desta forma, uma outra corrente de economistas vê a possibilidade de se tentar gerar indicadores mais consistentes e coerentes com o desenvolvimento sustentável.

A mais recente revisão da estrutura do $\mathrm{SCN}$, que vem sendo conduzida pela ONU desde 1988, procura contornar justamente três deficiências quando se trata da incorporação de elementos ambientais, como LUTZ \& MUNASINGHE (1991, p.19) apontam:

i. a contabilidade nacional não considera o impacto negativo da degradação do meio ambiente e dos recursos naturais na sociedade, que acabam afetando a produtividade sustentável da economia;

ii. a depreciação do capital natural (água, ar, solo...) não é registrada, bem como a extensão dos efeitos que a qualidade ambiental possui sobre a saúde e bem-estar da 
sociedade; e,

iii. os custos de despoluição, normalmente chamados de despesas defensivas ${ }^{17}$, são considerados acréscimo de produto, quando realizados pelo setor governamental ou pelas familias, enquanto deveriam ser considerados custos sociais que afetam a manutenção da qualidade ambiental. Por outro lado, as perdas ambientais não são contabilizadas.

Segundo EL SERAFY \& LUTZ (1992, p.3), a questão das despesas defensivas passa a ser tão mais relevante quanto maior for o nível de industrialização do país em questão. Os custos da redução da poluição fazem apenas parte destes gastos, que deveriam, por exemplo, incluir também gastos com segurança nacional e gastos com reparos de automóveis e despesas médicas, decorrentes de acidentes.

Os países desenvolvidos, que já se conscientizaram da problemática da falta de sustentabilidade dos atuais padrões de desenvolvimento, desenvolveram sistemas para monitorar, seja fisicamente ou monetariamente, os padrões de utilização dos recursos naturais e ambientais (BARTELMUS et al., 1992; FONSECA, 1992). Basicamente consiste na contabilização das reservas iniciais, dos acréscimos durante o período (descoberta de novas reservas ou crescimento populacional), das revisões das estimativas prévias e dos decréscimos por extração e mortalidade natural. As diferenças

\footnotetext{
${ }^{17}$ Despesas defensivas são todas as aç̃es dos agentes econômicos no sentido de compensar, reverter ou evitar perdas ambientais. Estas despesas são os custos decorrentes do uso gratuito de um serviço ambiental. Serviço ambiental é a adição de bem-estar gerado pelo uso do recurso natural. Desta forma, a contrapartida dos serviços são as perdas (MOTTA. 1991, p. 10-11).
} 
entre um e outro país residem apenas na complexidade com que estas contas são tratadas.

Os melhores exemplos para esses casos são a França e a Noruega. THEYS (1992) descreve o sistema de contas do patrimônio natural francês, uma adaptação feita do norueguês, com a vantagem de vislumbrar uma ligação com o sistema de contabilidade social $^{18}$

Por outro lado, no caso da exaustão e degradação dos recursos naturais, não há uma ligação direta com o nivel de industrialização, mas sim pelo quanto as atividades econômicas dependem da extração dos recursos naturais, como freqüentemente ocorre nos paises em desenvolvimento.

Diante da escassez de informações ambientais necessárias para a avaliação do patrimônio natural ${ }^{19}$, o Banco Mundial, em auxílio à ONU, sugere a criação de um conjunto de contas ambientais em anexo ao SCN, preservando sua atual estrutura $^{20}$.

Simplificadamente esta estrutura consiste na incorporação de uma folha de balanço dos ativos naturais e ambientais, além dos ativos produzidos pelo homem (ver quadro 1), seguindo os princípios e regras estabelecidos no $\mathrm{SCN}$ proposto pela $\mathrm{ONU}$, bem como guardando as identidades contábeis entre os agregados macroeconômicos,

\footnotetext{
${ }^{18}$ O Japão também apresenta uma experiência bem sucedida no cálculo do Bem-Estar Nacional Líquido. Para tal foram estabelecidos padrões de qualidade ambiental e determinado em quanto as emissões correntes ultrapassavam esses padrões. Os custos das atividades empreendidas para redução dos níveis de poluição a níveis aceitáveis foram então estimados e descontados do PNB.

${ }^{19}$ Principalmente no que diz respeito aos países em desenvolvimento cujas preocupações estão centradas em problemas básicos (como saúde, educação, combate a fome e miséria, consolidação dos sistemas político e econômico. etc) e não para o meio ambiente.

${ }^{20} \mathrm{O}$ United Nations Statistical Office (UNSO) foi o órgão elaborador do "Draft Handbook on Environmental Accounting". onde apresenta a estrutura global analítica do Sistema de Contas Econômicas e Ambientais (SCEA, ou do inglês. SEEA-System of Integrated Environmental and Economic Accounting).
} 
Quadro 1. Estrutura do Sistema de Contas Ecológicas e Econômicas proposta pela UNSO'.

\begin{tabular}{|c|c|c|c|c|c|}
\hline \multicolumn{7}{c|}{$\begin{array}{c}\text { CONTAS AMBIENTAIS } \\
\text { Tabelas de estoque/utilização \& Folhas de Balanço }\end{array}$} \\
\hline Estrutura Básica \\
\hline
\end{tabular}

Fonte: VAN TONGEREN et al. (1991)

${ }^{\mathrm{I}} \mathrm{UNSO}=$ United Nations Statistical Office 
Legenda do quadro 1 (ordenada conforme citação no quadro)

Ko.p.ec. = Valor no início do período dos ativos econômicos produzidos

Ko.np.ec. = Valor no início do período dos ativos econômicos não-produzidos (recursos naturais)

Ko.np.env. = Valor no início do período dos ativos ambientais não-produzidos (recursos ambientais)

$\mathbf{P} \quad=$ Produção (Valor Agregado - Produto Interno Bruto)

$\mathbf{M}=$ Importações

$\mathbf{C}_{\mathbf{i}} \quad=$ Consumo intermediário

Ex $\quad=$ Exportações

C $\quad$ Consumo final

I = Investimento (ou formação bruta de capital)

Depr. = Depreciação do capital produzido

Yn = Produto Interno Líquido

In = Investimento líquido

Inp.ec. = "Investimento" nos ativos econômicos não-produzidos

Inp.env. = "Investimento" nos ativos ambientais não-produzidos

Depl.np.ec. = Depleção dos ativos econômicos não-produzidos

Depl.np.env. = Depleção dos ativos ambientais não-produzidos

Ci.depl. $=$ Custos devido à depleção (consumo intermediário) $=-($ Dpl.np.ec + - Dpl.np.env. $)$

Yn1 = Produto Ambientalmente Ajustado Líquido 1 (considera Ci.depl.)

Ian.ec.1 = Acumulação líquida de ativos econômicos $1=$ IAn.ec. $2=\operatorname{In}+$ (Inp.ec. - Depl.np.ec. $)$

Ian.env1 $=$ Acumulação líquida de ativos ambientais $1=-$ (Inp.env + Depl.np.ec. $)$

Ci.degr. = Custos devido à degradação (consumo intermediário) $=-($ Degr.np.env.)

Degr.np.env. = Degradação do ativos ambientais não-produzidos

Yn2 = Produto Ambientalmente Ajustado Líquido 2 (considera Ci.depl e Ci.degr.)

Ian.ec. 2 = Acumulação líquida de ativos econômicos 2

Ian.env2 $=$ Acumulação líquida de ativos ambientais $2=-($ Inp.env. + Depl.np.ec. + Degr.np.env. $)$

Rev.p.ec. = Reavaliação dos ativos econômicos produzidos (para fins de complementaridade)

Rev.np.ec. = Reavaliação dos ativos econômicos não-produzidos (para fins de complementaridade)

Rev.np.env. = Reavaliação dos ativos ambientais não-produzidos (para fins de complementaridade)

K1.p.ec. = Valor no final do período dos ativos econômicos produzidos

K1.np.ec. = Valor no final do período dos ativos econômicos não-produzidos

K1.np.env. = Valor no final do período dos ativos ambientais não-produzidos 
como renda e despesa, valor adicionado e demanda final.

O motivo para a distinção entre as duas medidas de renda líquida ambiental (Yn1 e Yn2) reside no cômputo do que se chama custos de depleção ${ }^{21}$ e custos de degradação. Os primeiros estão diretamente vinculados à valoração dos ativos que foram transferidos do universo de bens econômicos não-produzidos pelo homem para o uso econômico. Já na determinação dos custos de degradação, não há uma valoração de mercado direta para os recursos que estão inclusos no universo dos bens ambientais quenão são produzidos, onde se enquadram os recursos renováveis: solo, água e ar.

As características do Sistema Satélite de Contabilidade Ambiental e Econômica Integrada (SEEA - System of Integrated Environmental and Economic Accounting) foram sumarizadas por BARTELMUS et al. (1992, p.3-4) da seguinte forma:

i. Todos os fluxos e estoques relacionados ao meio ambiente são relacionados, com o objetivo de identificar a parte do PIB que reflete os custos necessários para compensar os impactos negativos do crescimento econômico, as chamadas despesas defensivas (anteriormente consideradas como acréscimo de produto);

ii. a contabilidade fisica dos recursos passa a ser integrada com a contabilidade ambiental monetária e folhas de balanço;

iii. os custos e beneficios ambientais são considerados. Este avanço permite expandir e

\footnotetext{
${ }^{21}$ Segundo VAN TONGEREN et al. (1991, p. 3-4), a palavra depleção, do inglês depletion, encontra-se associada à exaustão quantitativa dos recursos naturais, enquanto a palavra degradação refere-se à degradação qualitativa do ecossistema.
} 
complementar o SCN, observando dois pontos em específico: (1) o uso (depleção) dos recursos naturais na produção e demanda final e (2) as alterações não contabilizadas da qualidade ambiental (degradação), resultante da poluição e outros impactos da produção; de um lado, consumo e eventos naturais, e de outro, a proteção e a melhoria ambiental;

iv. a riqueza tangível é contabilizada visando a sua manutenção. O SEEA estende o conceito de capital, utilizando tanto o capital produzido pelo homem (man-made) quanto o capital natural, com o intuito de alertar para a possibilidade de um crescimento não sustentável e repensar os modelos de desenvolvimento. Como consequêencia, o SEEA irá incluir custos adicionais para a depleção e a degradação destes ativos naturais, que ampliam o conceito de formação de capital para acumulação de capital; e,

v. permite a elaboração e mensuração dos indicadores ambientais ajustados de produto e de renda. A consideração da depleção dos recursos naturais e das mudanças nos níveis de qualidade ambiental permite o cálculo de agregados macroeconômicos modificados, como o Produto Interno Líquido Ajustado Ambientalmente. Discussões vêm sendo conduzidas no sentido de se tentar chegar à Renda Nacional Ambientalmente Ajustada contabilizando, mais adiante, os efeitos dos impactos ambientais sobre o bem-estar.

Com o intuito de verificar a adequabilidade deste sistema satélite à forte limitação de recursos financeiros e escassez de dados encontrados maioria dos paises em 
desenvolvimento, estudos já foram realizados no México (VAN TONGEREN et al., 1991), Papua-Nova Guiné (BARTELMUS et al., 1992), Costa Rica (SOLÓRZANO et al., 1991), Mali (BISHOP \& ALLEN, 1989) entre outros.

No Brasil, alguns trabalhos na área de contabilidade ambiental também já foram realizados. O Instituto de Pesquisa Econômica Aplicada - IPEA destaca-se na condução de trabalhos nessa área. MOTTA (1991) propôs um sistema de contas ambientais para o Brasil, semelhante à estrutura contábil proposta por PESKIN (1992, p.65-78). Ajustes setoriais de renda em termos ambientais também foram feitos nos trabalhos de MOTTA \& MAY (1992) e MOTTA \& YOUNG (1992), tratando, respectivamente, das atividades de extrativismo mineral e de conversão da terra produtiva através da derrubada de florestas.

Quanto ao Estado de São Paulo, um trabalho da Secretaria do Meio Ambiente, em convênio com a Universidade de São Paulo, aborda exaustivamente a temática sobre contabilidade ambiental, traçando um paralelo com as limitações encontradas em nível de estado. Segundo ABLAS (1992, p.107-8), a proposta mais viável para a incorporação de questões ambientais nas contas sociais seria a de contabilizar os custos e beneficios ambientais, ou seja, os valores negativos e positivos, respectivamente, que serviriam para corrigir os agregados macroeconômicos do estado ${ }^{22}$.

Embora, tanto em nivel de estado como de país, haja falta de dados

\footnotetext{
${ }^{22}$ Entendc-se por efeitos negativos como sendo todas as modificações introduzidas no ambiente que levam a uma situação pior que a anterior (como o caso do desmatamento não-sustentável ou dos dejetos industriais e urbanos lançados aos cursos d'água); e efeitos positivos, aquelas modificações que procurassem melhorar a situação (o reflorestamento. a prospecção de novas reservas de recursos naturais - incrementando os estoques iniciais do capital natural).
} 
estatísticos suficientes para o desenvolvimento completo de contas ambientais, isso não significa que se deva esperar pela geração ou pelo aprimoramento das informações existentes para dar continuidade aos trabalhos de valoração. THEYS (1992, p. 50-52), sob esse ponto de vista, sugere uma proposta de ação para os países em desenvolvimento dividida em três estágios. O primeiro consistiria na condução de estudos pilotos, onde criar-se-ia uma conta central (contabilidade de estoques) para cada recurso considerado estratégico pelo país (água, solo, florestas, biodiversidade, pesca, etc). Seria um esforço inicial de levantamento dos dados existentes e de determinação de quais dados seriam necessários e os seus custos e condições técnicas de obtenção. Ao final desse primeiro estágio, seria possivel propor um programa inicial para organizar os dados ambientais existentes no país. O segundo estágio consistiria nos trabalhos de análise da inter-relação entre os recursos estudados e a economia. Nessa fase, seriam testados os diversos métodos de valoração monetária dos recursos. $O$ terceiro estágio seria a institucionalização do programa de ação estabelecido para se construírem as contas ambientais, ampliando seu escopo em termos do patrimônio natural do país e interligando os sistemas de informações existentes (banco de dados, redes de monitoramento e inventários). Isto permitiria estabelecer as ligações entre a economia e o meio ambiente, desenvolvendo modelos macroeconômicos prospectivos com o intuito de se determinarem os efeitos econômicos das políticas ambientais. Além disso, possibilitaria a mensuração das conseqüências de diferentes cenários de crescimento sobre os indicadores ecológicos.

Certamente o Brasil ainda caminha para o primeiro estágio. Entretanto, 
à medida que os trabalhos de valoração ambiental forem sendo conduzidos, uma massa de informações sobre as inter-relações entre economia e meio ambiente começará a surgir. No caso do presente trabalho, a determinação do valor da depreciação do recurso solo pela erosão é uma contribuição para o futuro desenvolvimento das contas ambientais estaduais.

\subsection{A erosão do solo agrícola}

A erosão do solo é um fenômeno natural que se mantém em equilibrio com o dinâmico processo de formação dos solos. Sua existência decorre da interação de fatores naturais: climáticos, topográficos, edáficos e biológicos. Entretanto, o rompimento deste equilíbrio, por exemplo, através da ação humana, removendo ou modificando a cobertura vegetal original, se traduz numa forte aceleração do processo erosivo, comprometendo os longos anos que foram necessários para a formação do chamado "ser" solo 23 (ver quadros 2 e 3 ).

Basicamente nas regiões tropicais, os agentes do processo erosivo são a água e/ou o vento. Em todo território nacional, a erosão hídrica é a mais freqüente. A erosão eólica ocorre mais em solos arenosos ou em solos situados em regiões sujeitas a secas periódicas (SCHULTZ, 1987, p.17).

${ }^{23}$ O solo não é apenas um agregado de material mineral (areia. silte e argila), mas se constitui num ambiente complexo formado ainda por mais três fases, além da sólida: a líquida. a gasosa e a biológica (VAN RAIJ. 1987, p.3). A cobertura vegetal que naturalmente é encontrada sobre os solos é reflexo da interação dessas quatro fases. Um solo pobre ou rico, com alta ou baixa capacidade de retenção de água, muito ou pouco aerado. com alta ou baixa atividade micro ou macrobiológica, dá suporte a diferentes tipos de vegetação. 
Quadro 2. Taxas de formação natural do solo, erosão natural e induzida pelo homem.

\begin{tabular}{|lc|}
\hline Taxa de formação natural & 0,5 a $2,5 \mathrm{~mm} / \mathrm{ano}$ \\
Taxa de erosão natural & 0 a $1,0 \mathrm{~mm} / \mathrm{ano}$ \\
Taxa de erosão induzida pelo homem & média de $2,0 \mathrm{~mm} / \mathrm{ano}$ \\
\hline
\end{tabular}

Fonte: SCHUMM \& HARVEY, 1982.

Elaboração: Autor.

Quadro 3. Idades relativas dos recursos naturais.

\begin{tabular}{|c|c|c|c|}
\hline Classificação & Recursos & $\begin{array}{l}\text { Idade } \\
\text { (Anos) }\end{array}$ & $\begin{array}{l}\text { Tempo de Reposição } \\
\text { (Anos) }\end{array}$ \\
\hline $\begin{array}{l}\text { Predominantemente } \\
\text { Não-Renováveis }\end{array}$ & $\begin{array}{l}\text { Recursos minerais: } \\
\text { · ouro-diamantes } \\
\text { Combustíveis fósseis: } \\
\quad \text { carvão-petróleo } \\
\text { Solos } \\
\text { Recursos florestais } \\
\text { Água: } \\
\text { · subterrânea } \\
\text { 'superficie (ciclo hidro- } \\
\text { lógico) } \\
\text { Produtos agrícolas: } \\
\text { · culturas }\end{array}$ & $\begin{array}{c}10^{8}-10^{9} \\
10^{3}-10^{4} \\
10^{3}-10^{1} \\
10^{3}-10^{0} \\
10^{0} \\
10^{0}\end{array}$ & $\begin{array}{l}\text { bilhões de anos } \\
\text { milhões de anos } \\
\text { milhares de anos } \\
\text { dezenas a milhares de anos } \\
\text { um a milhares de anos } \\
\text { um ano } \\
\text { um ano }\end{array}$ \\
\hline
\end{tabular}

Fonte: SCHUMM \& HARVEY, 1982.

BELLINAZZI JUNIOR et al. (1981, p.127) estimaram que quinze milhões de hectares, ou $80 \%$ da área cultivada no Estado de São Paulo, estejam sofrendo processo erosivo além dos limites de tolerância ${ }^{24}$. Segundo estudos realizados no IAC, as

\footnotetext{
${ }^{24}$ É a quantidade de solo que pode ser perdida pela erosão. mantendo ainda a sua capacidade produtiva ao longo do tempo.
} 
tolerâncias de perda de solo no Estado de São Paulo variam de 4,0 a 15,0 t/ha/ano, sendo 4,5 a $13,4 \mathrm{t} / \mathrm{ha}$ /ano para solos com horizonte " $\mathrm{B}$ " textural, e de 9,6 a $15,0 \mathrm{t} / \mathrm{ha}$ /ano para solos com horizonte "B" latossólico (BELINAZZI JUNIOR et al., 1981, p.129). Esses mesmos autores fizeram uma previsão de que o estado perde aproximadamente 200 milhões de t/ano de solo. Considerando apenas a área ocupada com exploração agropecuária no Estado de São Paulo, este valor representa uma perda de 1,2 mm de solo cultivável por ano, ou seja $1,2 \mathrm{~cm}$ ao longo de uma década.

Muitas vezes, o processo de erosão é imperceptível. Esta é uma característica da erosão hídrica do tipo laminar, que atinge boa parte da terra agricultável do país e cujo controle só é feito após constatados danos irreversíveis ao solo. Um outro tipo de erosão é em sulcos, um tipo de erosão hídrica, que facilmente evolui para uma voçoroca, quando as condições são propícias e nenhum controle é feito. Apesar de não ser objeto do estudo, a erosão por voçorocas apresenta grande importância em termos ambientais, principalmente para áreas urbanas, devido ao grande volume de solo movimentado. Por exemplo, num curto prazo de tempo, uma represa ou lago de abastecimento de uma cidade pode ser totalmente assoreado, causando danos sociais, ambientais e econômicos de grande magnitude. Dada a gravidade desses tipos de problema, trabalhos de mapeamento das áreas mais críticas do Estado de São Paulo foram realizados pelo Departamento de Água e Esgotos Estadual (DAEE), conduzidos inicialmente na Bacia do Peixe-Paranapanema (MARTIN et al., 1991, p.182).

Um dos fatores que, reconhecidamente, mais contribui ao processo erosivo é ação antrópica, pela remoção da vegetação natural, pela movimentação sobre o 
solo com maquinário pesado - pulverizando a estrutura física, e pela aplicação excessiva de fertilizantes e corretivos - dispersando o colóide do solo. No caso do Estado de São Paulo, uma vez que as terras agricultáveis apresentam-se praticamente no limite de sua utilização (BELLINAZZI JUNIOR et al., 1981, p.117; MARTIN et al., 1991, p.163), outra alternativa não resta senão a intensificação do uso dos fatores de produção com vistas ao aumento da renda agropecuária, através do aumento de produtividade (ou migração para estados que possuam áreas a serem exploradas). $\mathrm{O}$ modelo de expansão da fronteira agrícola há muito se esgotou para a região Sul-Sudeste do país. Dos 24.732 .000 $\mathrm{ha}^{25}$ de área total que São Paulo possui, aproximadamente $75 \%$ vêm sendo utilizados, desde o início da década de oitenta, em atividades agropecuárias e silviculturais (ver figura 3). O grande desafio reside em promover esta intensificação gerando o mínimo de degradação e obedecendo às limitações de cada tipo de solo, observando os mapas de capacidade de uso e a racionalização no uso dos insumos modernos.

Se as classes de capacidade de uso das terras do Estado de São Paulo fossem rigorosamente seguidas (ver quadro 4), a área mínima a ser ocupada com reflorestamento e mata nativa deveria ser de $4.151 .200 \mathrm{ha}^{26}$; em 1991 , esta área não passava de 3.053.499 ha, ou seja, no mínimo, um milhão de hectares encontrava-se fora de sua capacidade de uso, expostos ao processo erosivo.

\footnotetext{
${ }^{25}$ Existe discordância quanto ao valor da área total do Estado de São Paulo, que varia segundo Secretarias. A Secretaria da Agricultura adota o valor de 24.860 .000 ha. enquanto para a Secretaria do Planejamento. o valor supra citado. Os dois valores aparecem divulgados dentro das mesmas publicações de anuários estatísticos do Estado de São Paulo.

${ }^{26}$ Chegou-se a esse valor somando-se a área correspondente à classificação VIII e a correspondente à classificação VII. uma vez que para declividades acima de $40 \%$, praticamente não há restrições para o reflorestamento.
} 
41.
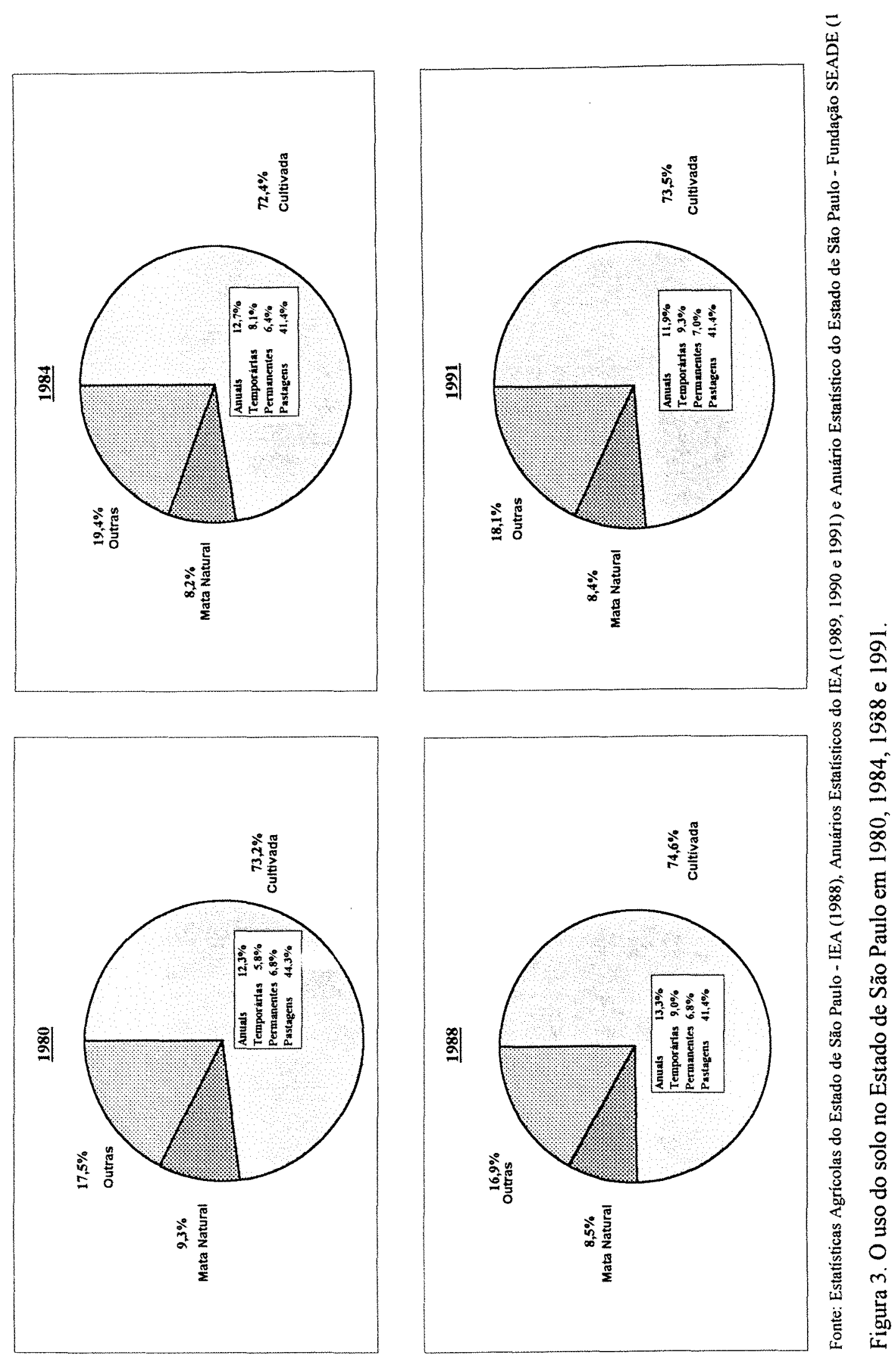
Quadro 4. Classes de capacidade de uso das terras do Estado de São Paulo, distribuição, áreas abrangidas, declividades, uso intenso mais recomendado e grau de limitação para este uso.

\begin{tabular}{|c|c|c|c|c|c|}
\hline $\begin{array}{l}\text { Classes de capa- } \\
\text { cidade de uso }\end{array}$ & $\begin{array}{l}\text { Área } \\
\mathrm{em} \mathrm{ha}\end{array}$ & $\begin{array}{l}\% \text { da área } \\
\text { do estado }\end{array}$ & Declividade & $\begin{array}{c}\text { Uso intenso } \\
\text { mais recomendado }\end{array}$ & $\begin{array}{c}\text { Grau de limitação } \\
\text { para esse uso }\end{array}$ \\
\hline I & (1) & (1) & (1) & agricultura & nulo - ligeiro \\
\hline II & (1) & (1) & (1) & agricultura & moderado \\
\hline III & 7.379 .400 & 29,80 & até $12 \%$ & agricultura & severo \\
\hline \multirow[t]{3}{*}{ IV } & 3.813 .450 & 15,30 & $12-20 \%$ & agricultura & muito severo \\
\hline & & & & (ocasional) & \\
\hline & & & & pastagem & nulo - ligeiro \\
\hline IVf & 4.189 .100 & 16,90 & até $12 \%$ & pastagem & nulo - ligeiro \\
\hline V & 674.600 & 2,70 & planas & pastagem & moderado \\
\hline \multirow[t]{2}{*}{ VI } & 1.448 .550 & 5,70 & $20-40 \%$ & pastagem & moderado \\
\hline & & & & reflorestamento & moderado \\
\hline \multirow[t]{2}{*}{ VIf } & 2.977 .600 & 12,00 & até $12 \%$ & pastagem & moderado \\
\hline & & & & reflorestamento & moderado \\
\hline \multirow[t]{2}{*}{ VII } & 3.076 .400 & 12,30 & $+\operatorname{de} 40 \%$ & pastagem & muito severo \\
\hline & & & & reflorestamento & nulo - ligeiro \\
\hline VIIf & 137.300 & 0,60 & até $12 \%$ & --- & -- \\
\hline VIII & 1.074 .800 & 4,30 & $\begin{array}{l}\text { escarpas de } \\
\text { serras } \\
\text { e montanhas }\end{array}$ & preservação e lazer & --- \\
\hline Área urbana & 88.800 & 0,40 & -- & -- & -- \\
\hline Total & 24.860 .000 & 100,0 & -- & $\cdots$ & -- \\
\hline
\end{tabular}

Fontc: Adaptado de CHIARINI e DONZELLI (em MARTIN et al., 1991, p. 129) e VASQUES FILHO (1986, p.4).

${ }^{(1)} \mathrm{A}$ árca e declividade das classes I e II foram computadas nos valores da classe III. 
Cabe ressaltar, no entanto, que a utilização do solo, respeitando as classes de capacidade de uso, por si só não garante a sustentabilidade da produção agropecuária. CUNHA et al. (1993), conduzindo estudos sobre a agricultura nos cerrados, concluíram que a garantia da sustentabilidade da produção depende muito mais da adequabilidade da tecnologia de produção utilizada com relação às características do solo, do que a simples ocupação do solo em função dos mapas de capacidade de uso ${ }^{27}$.

Embora existam técnicas eficientes de controle da erosão testadas e divulgadas pelos órgãos competentes de pesquisa e extensão rural, a sua utilização ainda é consideravelmente baixa entre os produtores rurais. CUNHA et al. (1993, p.41) observaram que, enquanto a oferta de terra for elástica, a adoção de tecnologias que sejam poupadoras do recurso em questão só seria feita pelo produtor caso fosse criada escassez via regulamentação (o que não se aplica ao Estado de São Paulo), ou criando tecnologia que, além de poupar o recurso solo, reduza também os custos de produção (como exemplificaram com o plantio direto do milho). Para o Estado de São Paulo, por exemplo, BELLINAZZI JUNIOR et al. (1981) consideram, em suas estimativas de erosão, que a adoção de técnicas conservacionistas é responsável pela redução de $15 \%$ do total de solo perdido.

\subsubsection{Os impactos ambientais}

A importância da erosão do solo como externalidade da atividade

\footnotetext{
${ }^{27}$ Superpondo mapas de uso efetivo com mapas de aptidão agrícola, mesmo que com pequena escala ( $1: 10.000 .000)$. os autores concluiram que o uso da terra para fins diferentes do recomendado não era regra. mas exceção.
} 
agropecuária se dá pela extensão com que seus efeitos são sentidos e pelas múltiplas atividades econômicas que acaba afetando. Segundo HUFSCHIMIDT et al. (1983, p.45), "um efeito externo surge quando a função utilidade ou produção de uma pessoa está sujeita às atividades de outras pessoas. As externalidades podem ser boas ou más". Particularizando a definição para os estudos da economia do meio ambiente, acrescenta: "externalidades que afetam a qualidade ambiental surgem quando os custos sociais e beneficios dos efeitos sobre o ambiente não são levados em consideração pela pessoa ou grupo que cria os efeitos".

Assim ocorre com as atividades agropecuárias, que, na ausência de padrões ambientais definidos e de legislação ou fiscalização apropriadas, geram uma amplitude de efeitos negativos que certamente superam em muito o beneficio de prover a sociedade de alimentos. A erosão do solo é apenas uma das diversas externalidades que essas atividades causam ao ambiente (ver figura 4).

O campo erodido, ou a unidade produtiva que o contém, é a primeira instância do largo espectro de danos ambientais ocasionados pelo processo erosivo. De imediato, como reflexo do carreamento, pela enxurrada, das partículas físicas e de material orgânico e inorgânico, a produtividade agrícola do solo é afetada, com maior ou menor intensidade, dependendo do tipo de solo, bem como das condições ambientais. No caso dos solos brasileiros, sua profundidade e boa estruturação garantem uma rápida recuperação em termos de produtividade com adubação química ou orgânica ${ }^{28}$.

\footnotetext{
${ }^{28}$ Segundo experimento conduzido por SPAROVECK et al. (1992) em casa de vegetação com arroz, dos oito solos estudados. cinco não apresentaram variação significativa de rendimento relativo com relação à simulação de profundidade do efeito da erosão do solo. Os teores de matéria orgânica, por sua vez. determinaram fortemente a produtividade do arroz. nas camadas superficiais.
} 
45.

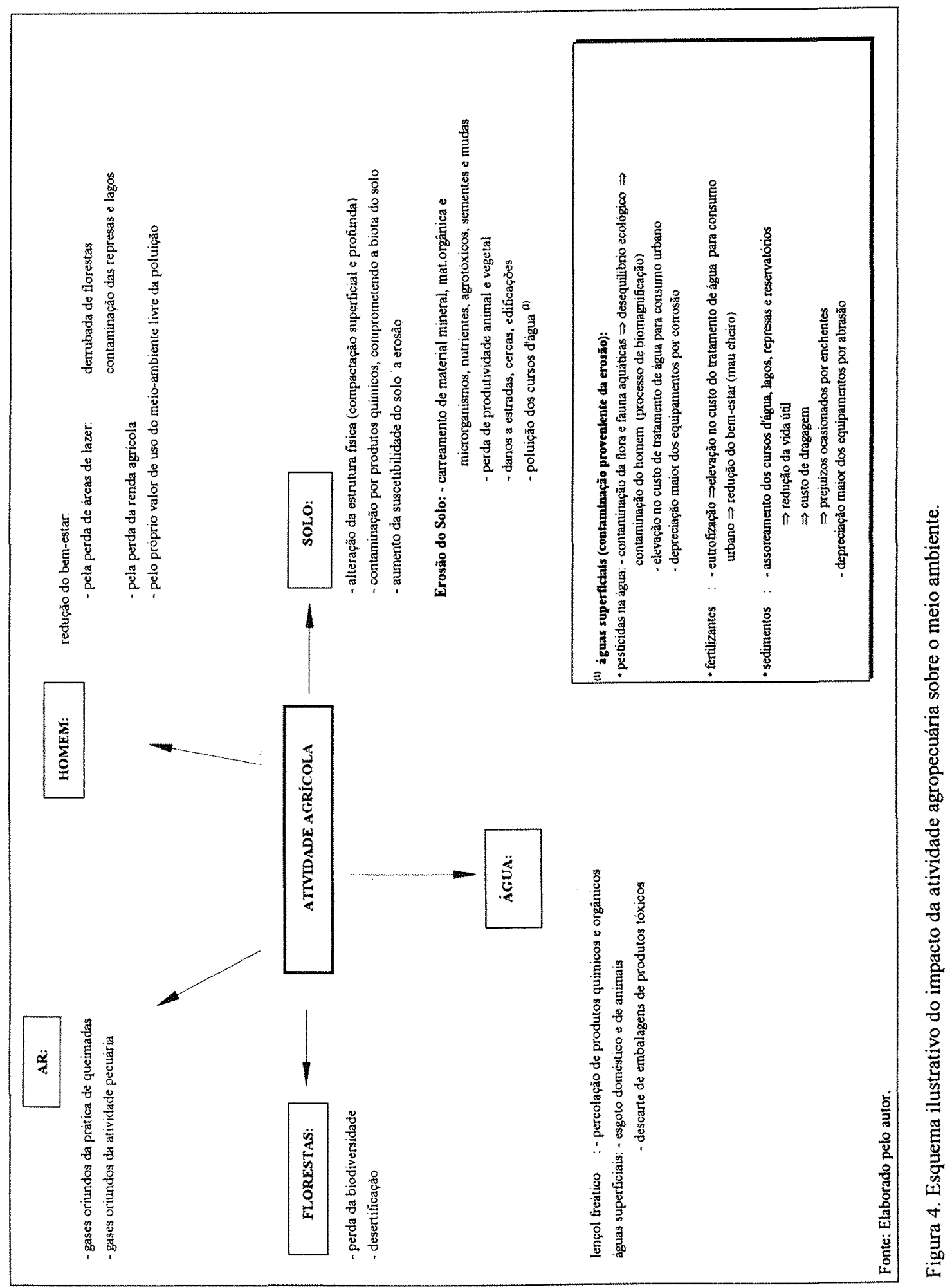


Em solos de clima temperado, por possuírem, de forma geral, menor profundidade, a perda de uma pequena lâmina de solo é fator que limita cada vez mais o cultivo agrícola. Mas, independente do tipo de solo, a erosão acarreta incrementos nos custos de produção, seja pela necessidade de reposição dos fertilizantes aplicados por ocasião do plantio, pelas sementes ou mudas carreadas pela enxurrada, ou pela perda direta de renda devido à queda da produtividade.

Todo esse volume de solo carreado gera impactos fora da unidade produtiva, a jusante dos campos erodidos. É neste sentido que a erosão é considerada como a principal fonte não-pontual de poluição hídrica (non-point source water pollution). Algumas estimativas americanas apontam que as fontes não-pontuais são os principais focos de poluição hídrica, cujas cargas correspondem a $73 \%$ da Demanda Biológica por Oxigênio (DBO) total, $99 \%$ dos sólidos suspensos, $83 \%$ dos sólidos dissolvidos, $82 \%$ do nitrogênio, $84 \%$ do fósforo e $98 \%$ das bactérias encontradas nos cursos d'água americanos (CLARK II et al., 1985). Estudos da agência de proteção ambiental americana (Environmental Protection Agency - EPA) indicam que a erosão do solo em regiões agrícolas é a principal preocupação em $47 \%$ das 367 mil milhas de cursos d'água americanos.

Para fora da unidade produtiva, os danos se refletem na contaminação dos corpos hídricos pelos sedimentos, defensivos e nutrientes carreados. CLARK II et al. (1985) realizaram vasta pesquisa compilando as informações existentes sobre os efeitos da erosão do solo na qualidade da água. Os impactos foram divididos naqueles causados pelas partículas do solo enquanto presentes no curso d'água (in-stream impacts) e nos 
que ocorrem antes ou depois das partículas de solo atingirem o curso d'água (off-stream impacts) (ver quadro 5).

\subsubsection{A contabilidade física}

Segundo EL SERAFY \& LUTZ (1992, p.5), "as medidas físicas são nitidamente condições sine qua non, sem as quais a contabilidade em termos monetários não pode ser empregada". Entretanto, a escassez das informações é um dos grandes problemas encontrados na área de contabilidade ambiental. Quando existem, encontramse dispersas.

Quanto à erosão do solo, há modelos paramétricos que captam o volume de solo perdido. Normalmente, estas estimativas são feitas através de modelos matemáticos que expressam a ação dos principais fatores que influenciam a erosão pela chuva .

O modelo mais difundido é o da Equação Universal de Perda do Solo ${ }^{26}$ (EUPS, ou do inglês, USLE), para previsão da perda média anual pela erosão laminar e em sulcos (FOSTER, 1988, p. 102).

\footnotetext{
${ }^{26}$ A EUPS é descrita da seguinte forma: $\mathbf{A}=$ R.K.L.S.C.P onde, $A=$ taxa de erosão anual média calculada por unidade de área (t/ha/ano);

$\mathrm{R}$ = fator de crosividade climática - é o índice de erosão causado pela chuva ( $\mathrm{MJ} / \mathrm{ha} \cdot \mathrm{mm} / \mathrm{ha})$, sendo $\mathrm{R}>0$; $\mathrm{K}$ = fator de erodibilidade do solo - é a susceptibilidade do solo à erosão [t/ha.(MJ/ha.mm/ha)], sendo $0<\mathrm{K}<1$ :

LS = fator topográfico - é a razão, em termos de perdas do solo, entre uma área com um comprimento de rampa (L) e declive (S)qualquer e uma outra com comprimento de rampa de $25 \mathrm{~m}$ e declive uniforme de $9 \%$, sendo $0<(\mathrm{L} \cdot \mathrm{S})<1$ :

$\mathrm{C}=$ fator uso e manejo de solo - razão entre perdas de solo de um terreno cultivado em dadas condições e as perdas correspondentes de um terreno mantido continuadamente desnudo, sendo $0<\mathrm{C}<1$; $\mathrm{P}=$ fator prática conservacionista - é a razão entre as perdas de solo de um terreno cultivado com determinada prática e as perdas de solo quando se planta morro abaixo, sendo $0<\mathrm{P}<1$.
} 
Quadro 5. Impactos da erosão para fora da unidade produtiva.

\begin{tabular}{|l|l|}
\hline A) Danos internos aos recursos hídricos (in-stream damages) \\
\hline 1. Impactos biológicos: & $\begin{array}{l}\text { os sedimentos podem extinguir fontes de alimentação, } \\
\text { alterar o habitat e, diretamente, destruir os organismos } \\
\text { aquáticos; } \\
\text { os nutrientes, estimulando o crescimento de algas 29 } \\
\text { bloqueiam a luz solar, por consequência, o desenvolvi- } \\
\text { mento de diversas formas aquáticas que da luz } \\
\text { dependem; } \\
\text { os pesticidas envenenam e transmutam os organismos } \\
\text { aquáticos, podendo muitas vezes levá-los à extinção } \\
\text { principalmente no que diz respeito às formas mais } \\
\text { frágeis); }\end{array}$ \\
\hline $\begin{array}{l}\text { espécies de valor esportivo, como a truta, podem ser } \\
\text { substituídas por espécies de menor valor; } \\
\text { a pesca recreativa é dificultada pela turbidez da água; } \\
\text { o assoreamento e o crescimento excessivo de mato } \\
\text { interferem nos passeios de barco e modalidades } \\
\text { esportivas na água. }\end{array}$ \\
\hline 2. Impactos recreativos:
\end{tabular}

Fonte: Adaptado de CLARK II et al. (1985).

\footnotetext{
${ }^{29}$ Este processo de enriquecimento de corpos d'água com nutrientes é denominado de eutrofização.
} 
Quadro 5. Impactos da erosão para fora da unidade produtiva .

<continuação>

\section{B) Danos externos aos recursos hídricos (off-stream damages)}

\begin{tabular}{|c|c|}
\hline 1. Danos por enchentes: & $\begin{array}{l}\text { os sedimentos podem agravar os danos por enchentes } \\
\text { de } 3 \text { formas: 1) pelo estreitamento dos leitos dos rios, 2) } \\
\text { por aumentar o volume da mistura de solo-água nas } \\
\text { enchentes e } 3 \text { ) muitos dos danos pelas enchentes são } \\
\text { causados mais diretamente pelos sedimentos do que pela } \\
\text { água. } \\
\text { o silte depositado pelas inundações pode causar alguns } \\
\text { danos a longo prazo para as terras agrícolas, como por } \\
\text { exemplo, a redução de produtividade (é claro que } \\
\text { existem casos onde este fenômeno ocorre ao contrário, } \\
\text { p.ex., Rio Nilo). }\end{array}$ \\
\hline $\begin{array}{l}\text { 2. Danos aos canais de condu- } \\
\text { ção de água: }\end{array}$ & $\begin{array}{l}\text { assoreamento e controle de plantas daninhas em canais } \\
\text { de drenagem e de irrigação. }\end{array}$ \\
\hline $\begin{array}{l}\text { 3. Danos à infra-estrutura d } \\
\text { abastecimento urbano de águ } \\
\text { potável: }\end{array}$ & $\begin{array}{l}\text { Devido aos sedimentos e elementos químicos carreados } \\
\text { pela erosão, há necessidade de se construir "basins" de } \\
\text { sedimentação, colocar cargas adicionais de coagulantes } \\
\text { químicos, limpar filtros com mais freqüência, usar filtros } \\
\text { de carvão ativado para remover elementos químicos } \\
\text { danosos à saúde, etc. }\end{array}$ \\
\hline 4. Outros impactos: & $\begin{array}{l}\text { Relacionados aos sais dissolvidos afetando a água } \\
\text { utilizada para o abastecimento de municípios e para as } \\
\text { indústrias; nutrientes e algas interferem nos sistemas de } \\
\text { resfriamento das usinas geradoras de energia elétrica à } \\
\text { base de vapor; e na água de irrigação para agricultura, } \\
\text { causando encrostamento e salinização. }\end{array}$ \\
\hline
\end{tabular}

Fonte: Adaptado de CLARK Il et al. (1985).

Mais recentemente, uma segunda geração de modelos de previsão de erosão está sendo desenvolvida nos EUA, para estimar a erosão hídrica. O projeto WEPP (Water Erosion Prediction Project) consiste num modelo dinâmico, que além das estimativas fisicas, é capaz também de simular as distribuições temporais e espaciais de perda de solo, contornado desta forma, a deficiência básica da EUPS que é a de não considerar a dinâmica do processo erosivo. Sendo um modelo computacional, viabiliza-se 
a aplicação para uma larga faixa de condições que podem não ser práticas ou econômicas para um teste de campo (ANGULO FILHO et al., 1990, p.1). A utilização deste modelo, no entanto, não será imediata. Ainda muita pesquisa há de ser feita com o intuito de adaptá-lo às condições brasileiras.

A partir das estimativas fisicas de perda de solo, conhecendo-se o teor médio de fertilidade de determinada área, pode-se prever a quantidade de nutrientes que está sendo perdida pelo processo erosivo (BELLINAZZI JUNIOR et al., 1981, p.127; MARTIN et al., 1991, p.163). O problema deste método consiste na dinâmica do processo de erosão, onde "os sedimentos transportados contêm uma proporção maior de argilas e outras finas partículas do que o solo do qual se originam" (CLARK II et al., 1985, p.29), causando um viés na medida da concentração de nutrientes carreados pelo processo erosivo.

Quanto à mensuração da perda de produtividade em função da erosão, os trabalhos existentes são limitados a particulares tipos de solo, culturas e condições de ambiente - campo ou estufas (SPAROVEK et al., 1991 e 1992). Assim torna-se dificil generalizar as conclusões dos trabalhos para uma unidade geográfica mais ampla, como, por exemplo, o estado. Nos Estados Unidos, modelos como o EPIC (Erosion Productivity Impact Calculator) foram desenvolvidos para se estimar a relação entre a erosão e a perda de produtividade. A interpretação dos resultados, no entanto, é problemática, uma vez que são mascarados pelos impactos positivos que o avanço tecnológico possui sobre a produtividade (KRAUSS \& ALMARAS, 1982). No Brasil, o 
fato de os solos brasileiros serem, em geral, muito profundos ${ }^{30}$, permite que a produtividade seja recomposta rapidamente, somente com a utilização das práticas de adubação e de calagem que normalmente já são feitas pelo produtor (SPAROVECK et al., 1991)

Quanto aos impactos erosão sobre a biota do solo, os trabalhos ainda são muito restritos. SILVEIRA et al. (1993) conduziram estudos sobre as alterações na comunidade microbiana em solos afetados pelo processo erosivo. Os resultados preliminares indicam haver substancial perda da flora e fauna, sem recuperação, a curto prazo, dos niveis originais da população mesmo utilizando-se adubação orgânica e química. Entretanto, é um estudo ainda restrito, mas que poderá, no futuro, tornar-se um novo item a ser agregado às estimativas ambientais da depreciação do recurso solo.

Para que um trabalho completo sobre a avaliação dos danos causados aos recursos hídricos pela erosão do solo fosse realizado, seriam ainda necessários dados primários do tipo: parcela de contribuição da erosão agrícola com nutrientes, pesticidas e sedimentos para os recursos hídricos; estudos que determinem a persistência, principalmente, dos pesticidas nos corpos hídricos, para desta forma caracterizar seu potencial poluidor, à semelhança do trabalho feito por PARIS \& LEWIS (1973).

Alguns trabalhos são encontrados na literatura nacional, no entanto, a especificidade de muitos dificulta a extrapolação para níveis mais amplos de impacto.

\footnotetext{
30 "O efeito da erosão laminar nos solos profundos é mais dificil de se estimar. Um solo uniforme de $2 \mathrm{~m}$ de espessura sobre a rocha matriz, sendo erodido a uma taxa de $23 \mathrm{t} / \mathrm{ha}$ (o dobro da permitida), requereria mais de 1.000 anos para ser reduzido a $30 \mathrm{~cm}$. Por outro lado, um solo de topo de montanha com um horizonte $B$ de $20 \mathrm{~cm}$, e sofrendo as mesmas taxas de erosão. perderia todo seu solo de superficie em 136 anos, e. provavelmente tornar-se-ia anti-econômico para a agricultura em menos da metade do tempo"(DREGNE, 1982, p.11).
} 
CABRAL JÚNIOR (1977) caracteriza a qualidade da água de drenagem de uma área irrigada cultivada com batata. Os resultados do trabalho poderiam ser extrapolados para outras regiões, como por exemplo uma microbacia hidrográfica cujo cultivo predominante seja de batata. No entanto, o trabalho foi realizado sobre uma cultura pouco representativa em termos de área no Estado de São Paulo (apenas $0,4 \%$ da área utilizada para fins agrícolas).

SCHMITT (1992) comenta que a eutrofização dos lagos do Guarapiranga e Rio Grande tem causado problemas de gosto e odor na água de abastecimento. E, que, para contornar esse problema, algumas medidas deveriam ser tomadas, como: i. controle hidrobiológico do reservatório; ii. uso do sulfato de cobre como algicida; iii. uso de carvão ativado em pó; e, iv. uso de cloreto férrico como coagulante alternativo do sulfato de alumínio. As estimativas desses custos adicionais para o tratamento das represas não seriam uma tarefa muito dificil. O problema é que o estudo está voltado para a zona urbana, e não se tem uma idéia de quanto a agricultura deve estar contribuindo para o problema.

Constata-se, desta forma, que a erosão do solo pode influenciar, de forma considerável, as atividades econômicas que são realizadas ao longo de uma cadeia que se inicia na unidade produtiva até pontos mais distantes, como as cidades localizadas à jusante das fontes poluidoras. O processo de agregação destes custos ambientais, embora nem sempre factível pela limitação do dados, pode fornecer uma dimensão aproximada do quanto as metas de desenvolvimento econômico se distanciam da sustentabilidade. 


\section{FUNDAMENTOS TEÓRICOS}

\subsection{Métodos de avaliação econômica dos impactos da erosão do solo}

Os trabalhos de valoração deste estudo serão baseados no conceito de produção sacrificada, que é uma proxy do valor do serviço ou bem fornecido pelo ambiente. Ou seja, este conceito mede o valor da perda da produção agropecuária, dos custos de restauração das externalidades negativas geradas, etc. Como o objetivo do trabalho é o de se estimar o valor da depreciação do recurso solo no Estado de São Paulo gerada pelo setor agropecuário, enfatizar-se-á a metodologia encontrada em literatura sobre o impacto da erosão do solo dentro da unidade produtiva, seja ela para fins agropecuários ou para reflorestamento.

Encontram-se na literatura diferentes métodos de valoração que se baseiam na perda da renda agrícola em função da perda de produtividade ou na reposição dos nutrientes carreados pelo processo erosivo. BISHOP \& ALLEN (1989, p.5) sugerem que, havendo dados disponíveis, o valor da fertilidade do solo poderia ser medido através da diferença do valor de aluguel, ou venda de pontos, distintos apenas pelo grau de degradação do solo. Entretanto as dificuldades começam por encontrar pontos que permitam esta comparação, e em tentar separar as diversas variáveis que explicam o preço de determinada parcela de terra, dentre elas, proximidade de malha viária, 
existência de córregos d'água, usos anteriores, entre outros. No caso do trabalho de BISHOP \& ALLEN, a inexistência, em Mali, de um mercado de aluguel e venda de terras comprometeu, de imediato, a utilização desta metodologia.

A quantificação da perda da capacidade produtiva do solo torna-se assim um método empiricamente mais conveniente na atribuição de um valor econômico à degradação do recurso solo. Como, em qualquer ativo, o valor do recurso solo seria igual ao valor presente dos futuros ganhos potenciais que dele dependessem. SOLÓRZANO et al. $(1991$, p.34) sugerem, para mensurar o valor presente da perda de solo pela erosão, a seguinte equação:

$$
V S D=\left(R \cdot P_{r}-C \cdot P_{c}\right) / i
$$

onde,

VSD = Valor cconômico da degradação do solo;

$\mathbf{R}=$ Renda original obtida do solo;

$\mathbf{P}_{\mathbf{r}} \quad=\quad$ Perda proporcional de renda pela erosão;

$\mathrm{C}=$ Custos operacionais;

$\mathbf{P}_{\mathbf{c}}=$ Mudança proporcional nos custos operacionais causados pela erosão;

i $=$ Taxa de juro.

Um dos principais problemas destes método, conforme os próprios autores comentaram, reside no grande volume de informações, tecnicamente dificeis de serem obtidas, necessárias para poder aplicá-lo. Seria preciso que existissem dados técnicos como a relação entre as perdas fisicas e biológicas e a produtividade da cultura, por tipo de solo. Não tão dificeis mas necessários seriam os dados econômicos referentes aos custos de produção das culturas, detalhados em nível de trabalho, de insumos e de 
maquinário, assim como os volumes colhidos e os preços agrícolas. Mais um ponto importante diz respeito à necessidade de se isolar os efeitos dos ganhos de produtividade obtidos pelo aprimoramento tecnológico, de forma a determinar o quão mais produtiva seria a cultura não fosse o problema da erosão.

MARGULIS (s.d.) utilizou no México uma aproximação da perda de produtividade das principais culturas, considerando a diferença entre a produtividade projetada (assumindo não haver erosão) e a alcançada ou realizada. Este procedimento, como o autor comenta, assume que a diferença é causada somente pela erosão. Esta é uma pressuposição muito forte, uma vez que variações climáticas, surtos inesperados de doenças e pragas contribuem também para a redução na produtividade. Por outro lado, existem os efeitos positivos decorrentes dos avanços tecnológicos e da adequada aplicação de fertilizantes sobre a produtividade.

REPETO et al. (1989, p.42-53) estimaram o custo econômico da erosão do solo para a Indonésia utilizando os estudos de impacto da erosão sobre a produtividade, de acordo com vinte e cinco tipos de solo e entre dois grupos de culturas (as sensiveis à erosão, como milho, soja, arroz de sequeiro e feijão; e as não-sensíveis, como mandioca) e os dados disponiveis de contabilidade agrícola em nível de produtor (os custos de produção). Dependendo do sistema de produção (rentabilidade) e da importância relativa dos custos fixos de produção, estabeleceu-se uma relação entre a perda da receita agrícola e a queda de $1 \%$ da produtividade devido à erosão do solo. $\mathrm{O}$ valor econômico da erosão do solo foi determinado por: 
onde,

VEE = Valor cconômico da erosão do solo;

$\mathrm{A}=$ Área (em ha);

$\mathrm{Y}=$ Perda média de produtividade em função da erosão do solo (em \%);

$\mathrm{C}=\quad$ Custo anual da queda de $1 \%$ na produtividade (em u.m./ha).

Os custos de um por cento de declínio para cada sistema de produção e as quedas estimadas na produção em função da erosão do solo foram aplicados às áreas de agricultura de sequeiro. Os dados encontrados são válidos somente para o ano de 1985, mas foram extrapolados para os dez anos anteriores, considerando-se a variação nas taxas de erosão em função apenas da alteração no uso do solo. Os custos foram então extrapolados considerando-se que não havia mudanças significativas nos sistemas de produção e que a renda líquida mantinha-se com uma proporção fixa das receitas agrícolas.

No México, VAN TONGEREN et al. (1991) utilizaram os requerimentos médios de nutrientes por hectare, de acordo com o tipo de atividade, para avaliarem economicamente os totais de solo perdido, através dos preços dos fertilizantes. A perda de solo registrada na terra agricultável foi calculada pela seguinte equação:

$$
\text { VEAT }=(\mathbf{S T}-\mathrm{SF}) \cdot \mathbf{F} \cdot \mathbf{P F}
$$

onde,

VEAT = Valor da Erosão Total sobre o Solo Agrícola;

ST $=$ Superficie Total (em ha);

SF $=$ Superficie Fertilizada (em ha);

$\mathrm{F}=$ Requcrimento de Fertilizantes (em kg/ha);

PF $=$ Preço dos Fertilizantes (em u.m./kg). 
Algumas fortes pressuposições são assumidas nesta equação. Por exemplo, a perda de nutrientes seria contabilizada somente nas áreas que não foram fertilizadas. O valor da erosão é explicado, única e exclusivamente, em termos de requerimento de nitrogênio, potássio e fósforo; ainda, não foi considerado o custo da aplicação desses nutrientes.

Um procedimento similar foi adotado, por esses mesmos autores, para se calcular o valor da perda da erosão no caso de áreas ocupadas com pastagens:

$$
\text { VEGT }=(\text { FG . PFG }) \cdot(P \cdot C / R) . \text { SEG }
$$

onde,

\begin{tabular}{|c|c|c|}
\hline VEGT & $=$ & Valor da Erosão Total no Solo Destinado à Pecuária; \\
\hline FG & $=$ & Requerimento de Fertilizante (em kg/ha); \\
\hline PFG & $=$ & Preço do Fertilizante (em u.m./ kg); \\
\hline $\mathbf{P}$ & $=$ & Cabeças de gado por hectare (cabeça/ha); \\
\hline $\mathbf{C}$ & $=$ & Consumo anual de pastagem $(\mathrm{kg} / \mathrm{cabeça)}$; \\
\hline $\mathbf{R}$ & $=$ & Produtividade anual da pastagem por hectare $(\mathrm{kg} / \mathrm{ha})$; \\
\hline SEG & $=$ & Superficie Erodida Ocupada pelo Gado (em ha). \\
\hline
\end{tabular}

No Brasil, a avaliação econômica dos danos causados pela erosão à unidade produtiva restringe-se à quantificação fisica e monetária do volume de solo carreado e com ele o equivalente-fertilizante, referente aos nutrientes "lavados" (BELLINAZZI JUNIOR, 1981; MARTIN et al., 1991).

BELLINAZZI JUNIOR et al. (1981, p.128) apresentam, para o Estado de São Paulo, estimativas físicas e monetárias de perda do solo agrícola pelo processo de erosão. A partir de dados coletados em campo, foram estimadas as perdas médias de solo por hectare para as principais ocupações agro-silvopastoris do estado. A partir da 
consolidação dos levantamentos da safra agrícola estadual para o ano civil, calculou-se a perda de solo, em toneladas por hectare ( $t / h a)$. Conhecendo-se o teor médio dos principais nutrientes dos solos paulistas $(\mathrm{N}, \mathrm{P}, \mathrm{K}, \mathrm{Ca})$ e calculando-se a média destes para o estado, transformou-se a quantidade física estimada de perda do solo em quantidade química. Portanto, obter-se-ão resultados em toneladas de nutrientes por hectare. $\mathrm{O}$ valor monetário da perda física do solo é obtido transformando-se o valor de nutrientes perdidos em equivalentes de fertilizantes (a partir do teor de nutrientes declarado na formulação dos adubos). A valoração, propriamente dita, é feita utilizando-se os preços de mercado destes fertilizantes.

O resultado desse método é um valor proxy considerado razoável, frente ao problema da escassez de informações, como estimativa monetária da degradação do recurso solo. No entanto, algumas considerações devem ser feitas com relação à utilização desse método:

i. as perdas econômicas originadas da erosão do solo não se resumem apenas à lixiviação dos nutrientes. Outros fatores, não menos importantes, mas de dificil mensuração em sua grande parte, não são contabilizados. Por exemplo, as partículas fisicas de solo que são carreadas pelo processo erosivo, a diminuição da capacidade de retenção de água pelo solo e o material orgânico que também é carreado, levando com ele a riqueza natural da biota do solo;

ii. considera-se, nesta metodologia, que todo o nutriente perdido deva ser reposto. Porém, duas observações são necessárias: primeiro, o solo carreado pela erosão 
apresenta um teor de nutrientes maior que o solo original, uma vez que a parte removida é mais superficial, onde a concentração de matéria orgânica e elementos nutrientes é maior; segundo, o solo apresenta um nível de tolerância à perda de nutrientes, já que apresenta uma capacidade regenerativa natural, pelo fato de essa perda não afetar a produtividade. Assim sendo, a reposição deveria ser feita pelo diferencial entre o perdido e o tolerado ${ }^{31}$;

iii. na reposição dos nutrientes perdidos via aplicação de fertilizantes, deve-se considerar a eficiência dos mesmos, dado que apresentam impurezas, como é o caso do calcário. A metodologia em questão desconsidera este fato.

Com respeito às duas últimas considerações, SOLÓRZANO et al. (1991, p.34) apresentaram a seguinte equação para se estimar o valor da degradação do recurso solo:

$$
\text { VSD }=\left(Q N_{\text {tot }}-Q N_{\text {tol }}\right) \cdot\left(f_{a}\right) \cdot\left(P_{f}+C_{f}\right)
$$

onde,

$\mathbf{V S D}=$ Valor da degradação do solo;
$\mathbf{Q N}_{\text {tot }}=$ Quantidade total de nutrientes perdidos;
$\mathbf{Q N}_{\text {tol }}=$ Quantidade tolerável de nutrientes perdidos;
$\mathbf{f}_{\mathbf{a}}=$ Fator de eficiência do fertilizante;
$\mathbf{P}_{\mathbf{f}}=$ Preço de mercado do fertilizante;
$\mathbf{C}_{\mathbf{f}}=$ Custo de aplicação por unidade de fertilizante.

31 Vale ressaltar que a capacidade regenerativa da maior parte dos solos tropicais (em latossolos, principalmente) é muito baixa em relação aos nutrientes lixiviados. DE MARIA, Isabella Clerici (IAC, Seção de Conservação do Solo. Campinas). comunicação pessoal, 1995. 
Com relação a esta equação, duas observações, que também se aplicam ao método utilizado por BELLINAZZI et al., devem ser feitas:

i. o solo possui um limite natural. Próximo a este ponto, não mais adianta repor os nutrientes perdidos. A valoração nestes casos passa a assumir valores subjetivos, como o valor de existência do recurso em questão.

ii. a utilização de bens de mercado para valorar indiretamente os recursos ambientais apresenta uma séria limitação que é o comportamento independente daqueles com relação ao recurso. Quando os preços reais declinam ao longo do tempo, como por exemplo aconteceu com os insumos ao longo da década de oitenta, poder-se-ia ter a falsa ilusão que há diminuição na taxa de degradação do recurso.

Os esforços de valoração monetária referentes às estimativas de depreciação do recurso solo foram sumarizados no quadro 6 , com o intuito de mostrar a ordem de grandeza das estimativas calculadas. Vale ressaltar que, em grande parte, os valores encontrados representam limites inferiores das perdas monetárias estimadas decorrentes da erosão do solo. Os custos externos (ou off-site costs), percebidos pela sociedade, costumam ser algumas vezes maiores que os custos percebidos para a unidade produtiva. A nivel de Brasil, a relativa escassez de dados técnicos limita os trabalhos de valoração da depreciação do recurso solo ao custo de reposição em macronutrientes. 


\section{Quadro 6. Algumas estimativas monetárias de depreciação do recurso solo e de impactos sobre os recursos hídricos.}

\begin{tabular}{|c|c|c|c|}
\hline Fonte & Local & Estimativa & Observações \\
\hline Custos internos & on-site costs & & \\
\hline PAULET (1978) & $\begin{array}{l}\text { República } \\
\text { Dominicana }\end{array}$ & US\$ 453/ha ano & $\begin{array}{l}\text { valor relativo ao aumento no custo de } \\
\text { produção de alimentos. }\end{array}$ \\
\hline $\begin{array}{l}\text { MARGULIS } \\
\text { (s.d., p.6) }\end{array}$ & México & US\$ 50 milhões a.a. & $\begin{array}{l}\text { custo relacionado à perda de produ- } \\
\text { tividade. }\end{array}$ \\
\hline $\begin{array}{l}\text { MONTOYA \& } \\
\text { SORRENSON } \\
(1984)\end{array}$ & Paraná & $\begin{array}{l}\text { US\$ } 121 \text { a US\$ } 242 \\
\text { milhões a.a. }\end{array}$ & $\begin{array}{l}\text { valor estimado segundo a reposição de } \\
\text { macronutrientes. devido à erosão } \\
\text { hídrica e laminar. }\end{array}$ \\
\hline $\begin{array}{l}\text { MARTIN et al. } \\
\text { (1991) }\end{array}$ & São Paulo & US\$ 212 milhões a.a. & $\begin{array}{l}\text { pela reposição de macronutrientes, } \\
\text { devido à erosão hidrica e laminar, } \\
\text { inclusive na área urbana. }\end{array}$ \\
\hline $\begin{array}{l}\text { CAVALCANTI } \\
\text { (1985. p.1097) }\end{array}$ & $\begin{array}{l}\text { Bacia do rio São } \\
\text { Francisco (MG } \\
\text { e BA) }\end{array}$ & US\$ 1.30 bilhão $^{(1)}$ & $\begin{array}{l}\text { pela reposição de macronutrientes, } \\
\text { devido à erosão hídrica e laminar. }\end{array}$ \\
\hline Custos externos & off-site costs & & \\
\hline $\begin{array}{l}\text { CLARK } \quad(1985 . \\
\text { p.175) }\end{array}$ & EUA & $\begin{array}{l}\text { US } \$ 1,1 \text { a US\$ } 1,3 \\
\text { bilhão em } 1980\end{array}$ & $\begin{array}{l}\text { custos externos à propriedade agrícola } \\
\text { relacionados aos efeitos negativos dos } \\
\text { sedimentos aos recursos hídricos. }\end{array}$ \\
\hline $\begin{array}{l}\text { HITHZUHSEN } \\
(1984)\end{array}$ & EUA & $\begin{array}{l}\text { US\$ la US\$ } 3 \text { bilhões } \\
\text { ao ano }\end{array}$ & $\begin{array}{l}\text { referentes apenas aos gastos com } \\
\text { dragagem e tratamento de água }\end{array}$ \\
\hline
\end{tabular}

Obs.: MONTOYA \& SORRENSON (1984), HITHZUHSEN (1984) e PAULET (1978) foram citados em MENCK (1993).

(1) Dólar médio de julho/94 = R\$0,93 


\subsection{Metodologias para ajustar ambientalmente a renda nacional}

$$
\text { Os ajustes necessários para transformar a renda nacional }
$$

tradicionalmente calculada ${ }^{32}$ em sustentada podem ser feitos tomando-se por base dois pontos básicos (LUTZ, 1992, p. 02):

i. as despesas com proteção/restauração do meio ambiente;

ii. a contabilização da degradação/exaustão dos recursos naturais.

As despesas de proteção/restauração são geralmente computadas no cálculo do produto, aumentando-o. Passa pela já mencionada idéia sobre a derrubada de uma floresta e o incremento na renda nacional em função da venda de madeira e dos investimentos necessários para a instalação da nova atividade, ou da recuperação de uma área degradada em função da atividade mineradora.

As preocupações acerca da proteção e restauração do ambiente são geralmente mais enfatizadas nos países desenvolvidos. A estabilidade de suas economias e sociedades, ao longo do tempo, permite que haja uma grande preocupação em torno do incremento do bem-estar, dada a alta renda per capita que já possuem ${ }^{33}$.

No caso dos países em desenvolvimento, a questão da degradação/exaustão é evidenciada em função da grande dependência que a economia de muitos países possui com relação à base dos recursos naturais e da forma não sustentada

\footnotetext{
${ }^{32}$ Estes ajustes. a rigor, estariam na direção de obter um produto doméstico sustentável. Segundo HUETING et al. (1992, pg.37), para se chegar ao conceito de renda sustentável deveriam ser feitas correções ambientais para as importações e exportações. As atividades conduzidas por muitos países industrializados acabam resultando na exaustão/degradação de recursos naturais e ambientais em muitos outros países.

${ }^{33}$ São estes custos de proteção e de restauração. incorridos pelos países desenvolvidos, mas nem sempre pelos $\mathrm{cm}$ desenvolvimento. que têm sancionado a imposição de um novo mecanismo de proteção nãotarifária no comércio internacional. os selos ambientais.
} 
de exploração. Apesar de haver alguma preocupação com a formulação de política ambiental, as prioridades ainda se encontram centradas em problemas básicos como educação e saúde, além dos problemas de instabilidade política e econômica.

$$
\text { Quanto à mensuração da degradação/exaustão, existem duas }
$$

abordagens em literatura:

i. o princípio da depreciação;

ii. o método do custo de uso (user-cost).

A depreciação do capital natural pode ser mensurada através de uma proxy, que seria o custo de reposição do material exaurido ou degradado. Por convenção, assume-se que o valor dos custos ambientais seja igual ao valor dos gastos com proteção ambiental gerados para combaterem a degradação ambiental. Ou seja, pressupõe-se que estes gastos, conhecidos também como despesas defensivas, não provoquem outros tipos de degradação (MUELLER, 1991, p.24).

Segundo DALY (1992, p.8), o desconto das despesas defensivas e o do capital natural consumido sobre as medidas de produto interno líquido dão origem ao produto interno líquido sustentável, que seria a medida mais próxima do conceito de renda verdadeira de Hicks.

$$
\text { SSNNP = NNP - DE - DNC }
$$

onde,

SSNNP $=$ Produto Interno Liquido Socialmente Sustentável;

NNP $=$ Produto Interno Líquido;

DE $\quad=$ Despesas Defensivas;

DNC = Degradação do Capital Natural. 
Uma das desvantagens deste princípio consiste no ajuste somente do produto líquido, permanecendo inalterados os valores do produto bruto, como afirma EL SERAFY (1992, p.12). Um exemplo extremo seria o caso de um país cujo produto seja originado $100 \%$ da extração de um recurso exaurivel, como o petróleo. Segundo o princípio da depreciação, para um PIB de 100 unidades monetárias (u.m.), teríamos um PIL ajustado ambientalmente (Produto Interno Líquido) igual a zero, uma medida que segundo El Serafy "seria particularmente não edificante".

HARRISON $(1992$, p.21) sugere um outro tratamento com relação à introdução do capital natural no $\mathrm{SCN}$. As despesas efetuadas com proteção e recuperação ambiental (gastos defensivos) não deveriam ser descontadas do produto bruto agregado, conforme preconizam diversos economistas de recursos naturais, mas sim consideradas como acréscimo de produto (diversos ambientalistas costumam argumentar que a introdução de programas ambientais possui um efeito positivo sobre a geração de empregos na economia, o que na realidade é observado, uma vez que para esses programas há contratação de mão-de-obra, bens e serviços). A contabilização do consumo do capital natural, lançado com sinal contrário na estrutura de contas nacionais, compensaria o lançamento positivo do programa sobre o PIB, havendo uma mudança positiva no Produto Líquido e não no Produto Bruto. $\mathrm{O}$ que intuitivamente parece ser claro, uma vez que, com a adoção de despesas ambientais preventivas, a preservação do ambiente garantiria mais renda para ser consumida. E a renda disponível para ser consumida seria a renda líquida, e não a bruta (ver quadro 7). 


\section{Quadro 7. Efeito sobre o PIB pela inclusão de um programa de proteção ambiental (em unidades monetárias).}

\begin{tabular}{|c|c|c|c|c|}
\hline & \multicolumn{2}{|c|}{ SCN atual } & \multirow{2}{*}{$\begin{array}{c}\text { revisão } \\
\text { s/ } \\
\text { programa }\end{array}$} & \multirow{2}{*}{$\begin{array}{l}\text { proposta } \\
\mathrm{c} / \\
\text { programa }\end{array}$} \\
\hline & $\begin{array}{c}\text { s/ } \\
\text { programa }\end{array}$ & $\begin{array}{c}\mathrm{c} / \\
\text { programa }\end{array}$ & & \\
\hline PIB & 100 & 105 & 105 & 105 \\
\hline $\begin{array}{l}\text { Depreciação do } \\
\text { capital produzido }\end{array}$ & 10 & 10 & 10 & 10 \\
\hline $\begin{array}{l}\text { Depreciação do } \\
\text { capital natural }\end{array}$ & n.a. & n.a. & 5 & 0 \\
\hline PIL & 90 & 95 & 90 & 95 \\
\hline
\end{tabular}

Fonte: HARRISSON (1989), p.21.

obs.: n.a. - não aplicável

Este exemplo do quadro 7 exprime de forma sintética como o capital natural, sob o enfoque da depreciação, deveria ser contabilizado, mas, ao mesmo tempo, demonstra a limitação que possui ao se trabalhar com uma medida agregada de renda pouco utilizada, a renda líquida.

Partindo de uma nação com um PIB hipotético de 100 unidades monetárias (u.m.), consumo de capital de 10 u.m., cuja mensuração das externalidades negativas causadas ao ambiente gera uma perda de 5 u.m., observa-se que, na atual estrutura do $\mathrm{SCN}$, a introdução de um programa de recuperação das perdas ambientais seria contabilizada como um "falso" acréscimo de produto bruto ${ }^{34}$ e líquido.

Pela revisão proposta por Harrison, esse acréscimo não seria observado, uma vez que as estimativas passadas do PIB, sem o programa de proteção

\footnotetext{
${ }^{34}$ Assim ocorre com o PIB estadual paulista e os programas ambientais que vêm sendo conduzidos pelo governo estadual (conservação das microbacias hidrográficas, despoluição do Rio Tietê, entre muitos outros).
} 
ambiental, seriam aumentadas de forma a permitir o consumo do capital natural. Apesar de pouco intuitivo, este artificio contábil permite evidenciar as mudanças que ocorrem em nível da renda que pode ser consumida segundo o conceito de sustentabilidade. Sem esse artificio, paises que estejam introduzindo programas de proteção, perceberiam um acréscimo tanto na renda bruta como na líquida, o que significaria que quanto pior o estado de degradação do ambiente, melhores seriam os indicadores de desempenho da economia. Da forma como Harrison propõe, observar-se-ia nesses países um estreitamento na distância entre o produto bruto e o líquido, à medida que esses programas de proteção fossem bem sucedidos em reconverter o estado de degradação do ambiente.

A crítica a esta forma de abordagem, por sua vez, consiste exatamente no ponto do Produto Interno Bruto manter-se inalterado. Este, por sua vez, é utilizado preferencialmente nas análises macroeconômicas, já que segundo Hicks (citado por EL SERAFY, 1992, p.13), o conceito de produto líquido é, na maior parte das vezes, arbitrário.

Surge então um método alternativo para tratar de questões de degradação/exaustão dos recursos naturais, que é a abordagem pelo user-cost (EL SERAFY, 1992, p10-18). No entanto, ele é mais adequado para recursos naturais negociáveis, como recursos florestais e minerais. A idéia do conceito consiste em dividir as receitas provenientes da extração de determinado recurso natural (R), líquida dos custos de extração em duas partes: uma que representa a renda que pode ser sustentavelmente consumida $(\mathrm{X})$; e outra que representa o montante a ser reinvestido de 
forma que esta atividade possa gerar, de forma infinita, uma renda ao explorador (R-X). R-X é o custo de uso, ou fator de depleção, que deve ser colocado de lado como investimento em capital e descontado integralmente do PIB. A partir da relação entre a renda verdadeira e as receitas totais, determinadas apenas pela expectativa de duração das reservas do recurso em questão (n) e da taxa de desconto (r), é possível determinar o valor do fator de depleção:

$$
\frac{X}{R}=1-\frac{1}{(1+r)^{(1+n)}}
$$

onde,

$\mathbf{X}=$ é a chamada renda verdadeira (true income);

$\mathbf{R}=$ é o valor do rent (o rendimento líquido do custo de operação e de capital);

$\mathbf{r}=$ taxa de desconto;

$\mathbf{n}=$ o número de períodos em que o recurso seria totalmente exaurido.

A grande vantagem deste método reside em não precisar que o estoque dos recursos existente seja valorado, dado que o mais importante é conhecer qual a contribuição da taxa corrente de extração do recurso em relação ao estoque avaliado em termos fisicos. Avalia-se somente o fluxo extraído no período considerado. Outra vantagem é a flexibilidade do método, ao permitir que a taxa de desconto utilizada, o nivel de extração e as estimativas das reservas possam ser alterados ${ }^{35}$. Quanto menores forem as taxas de desconto, mais se contribui para que o consumo do capital presente seja abdicado em função do consumo futuro.

\footnotetext{
${ }^{35}$ Mais detalhes sobre as diferenças entre as duas abordagens ver FOY (1991), MOTTA \& MAY
} (1992; 1994); MOTTA (1995). 
A utilização dessa abordagem para recursos como o solo e a água, aparentemente, não é muito direta. Para o solo, por exemplo, seria necessário conhecer o limite de tolerância do solo com relação às perdas por erosão, bem como a sua taxa de formação, de modo que se pudesse determinar a expectativa de vida do recurso. Além do mais, o solo não é diretamente comercializado, o que dificultaria um pouco a determinação de $\mathrm{R}$, que por sua vez dependeria da atividade agricola que estivesse sendo conduzida sobre o solo.

\subsection{Descrição da metodologia utilizada}

As dificuldades para se estimarem valores diretos para recursos que não são comercializados através de bens produzidos pelo homem, como é o caso do ar, do solo e da água, sugerem que os valores destes ativos sejam representados, no sistema de contas ambientais, como os custos requeridos para que determinado padrão de qualidade seja mantido (MUELLER, 1991, p.27).

O solo é considerado como sendo um recurso renovável, embora mais precisamente sua classificação esteja numa posição intermediária entre os recursos que são considerados renováveis e os não-renováveis. Sendo assim, os problemas ambientais relacionados com esse recurso referem-se mais à questão dos padrões de qualidade e menos à questão da depleção, ou exaustão do recurso (VAN TONGEREN et al., 1991).

Sendo o problema da erosão do solo caracterizado como uma questão de degradação ambiental, utilizar-se-á a abordagem da depreciação para se chegar a uma estimativa monetária. Por uma questão básica de disponibilidade de dados, essa valoração 
será feita em termos de custo de reposição dos nutrientes carreados e perdidos pelo processo erosivo.

A partir da revisão de literatura, encontraram-se duas metodologias que incorporam este princípio da reposição, mas que necessitam ser adaptadas à disponibilidade de dados técnicos existentes: a metodologia utilizada por BELINAZZI et al. (1981) e a de SOLÓRZANO et al. (1991).

$\mathrm{Na}$ primeira, não foram contabilizados os custos de aplicação dos fertilizantes. Na segunda, além dos custos, a determinação do quanto repor foi feita em função dos limites de tolerância de cada tipo de solo e da eficiência de aplicação dos fertilizantes.

A inclusão da variável custos de aplicação possui fundamentos econômicos ligados à proposta do trabalho. Quando se contabiliza o custo de aplicação do fertilizante que será reposto pela perda originada do processo erosivo, assegura-se que este montante não seja contabilizado como acréscimo de produto bruto, o que enviesaria, dessa forma, as estimativas deste indicador econômico. Ou seja, isso implicaria incorrer no erro de que quanto mais degradado estivesse o solo, maior seria o indicador agregado da renda gerada pelo recurso solo.

A questão do limite de tolerância poderia ser resolvida com a utilização do Sistema de Informações Geográficas, a partir dos mapas digitalizados do solo e do seu uso. No entanto, os estudos com a aplicação desse sistema ainda estão começando, e ainda não havia, ao longo do período estudado, um estudo de bandas espectrofotométricas para se determinarem os diversos usos do solo no Estado de São 
Paulo.

A inclusão da variável eficiência possui caráter iminentemente técnico. Durante a aplicação dos fertilizantes há perdas, dependendo das condições climáticas e das próprias características fisicas da formulação comercial. Isso significa que, para repor a quantidade de nutrientes perdida, é praticamente certo que sempre será necessário um pouco mais. Embora seja uma variável importante, não foram encontrados, a nível de estado nem de país, valores técnicos que permitissem esse ajuste. No caso do trabalho de Solórzano, os dados de eficiência de aplicação dos fertilizante foram obtidos a partir de comentários pessoais.

Portanto, neste estudo, os cálculos das estimativas monetárias acerca do valor que se pretende atribuir à degradação do solo podem ser simplificadamente expressos segundo a equação abaixo:

$$
\operatorname{VDS}=\left(\mathbf{Q N}_{\mathrm{tot}}\right) \cdot\left(\mathbf{P}_{\mathrm{f}}+\mathrm{C}_{\mathrm{f}}\right)
$$

onde,

VDS $=$ Valor da degradação do solo;

$\mathbf{Q N}_{\text {tot }}=$ Quantidade total de nutrientes perdidos, em equivalentes de fertilizantes;

$\mathbf{P}_{\mathrm{f}} \quad=\quad$ Preço de mercado do fertilizante;

$\mathrm{C}_{\mathrm{f}}=$ Custo de aplicação por unidade de fertilizante.

As etapas que serão seguidas para o processo de valoração econômica referente à perda de solo pela erosão são as seguintes:

i. obter série com a evolução da ocupação do solo (em ha), ao longo do período estudado; 
ii. obter estimativas de perda média de solo (em t/ha/ano), segundo sua utilização, ao longo do periodo estudado;

iii. obter estimativas médias agregadas do conteúdo de nutrientes $(\mathrm{N}, \mathrm{P}, \mathrm{K}$ e Ca$+\mathrm{Mg})$ no solo $(\mathrm{em} \%)$;

iv. chegar-se ao valor de $\mathbf{Q N}_{\text {tot }}$, a partir de i), ii) e iii), convertendo-se as toneladas de nutrientes em equivalentes de fertilizantes;

v. obter uma série de preços dos fertilizantes (equivalentes aos nutrientes estudados) mais utilizados $(\mathrm{em} \$ / \mathrm{t})$. Obtém-se $\mathbf{P}_{\mathbf{p}}$;

vi. estimar os custos de aplicação médios dos fertilizantes, de acordo com os sistemas de produção mais freqüentemente adotados $(\mathrm{em} \$ / \mathrm{t})$. Obtém-se $\mathbf{C}_{\boldsymbol{r}}$;

vii.obter, a partir da equação proposta (ver equação 8), a estimativa monetária do valor da depreciação do recurso solo (VDS). 


\section{RESULTADOS E DISCUSSÃO}

\subsection{A estimativa da degradação do recurso solo}

A evolução da área cultivada no Estado de São Paulo (ver tabela 2 e apêndices 3a-c), segundo os dados levantados pelo Instituto de Economia Agrícola, demonstra o impacto que o advento do Proálcool teve sobre a forma de ocupação do solo. Durante o periodo estudado, a contrapartida da redução na área de pastagens, culturas anuais e reflorestamentos foi um incremento de mais de $60 \%$ na área cultivada com culturas temporárias, dentre elas a cana-de-açúcar. A laranja, outra importante cultura para o Estado de São Paulo, também apresentou forte crescimento no período estudado, mais de $80 \%$, o que resultou no aumento de $3,20 \%$ da área ocupada com lavouras permanentes.

Através do trabalho de BELLINAZZI et al. (1981), foram obtidas as estimativas da perda média de solo por hectare e por cultura, nas condições observadas em 1981 (ver tabela 3). Essas avaliações são resultantes da aplicação da Equação Universal de Perda do Solo, onde são considerados os seguintes elementos: clima, erodibilidade do solo, topografia, uso e manejo do solo e práticas conservacionistas 


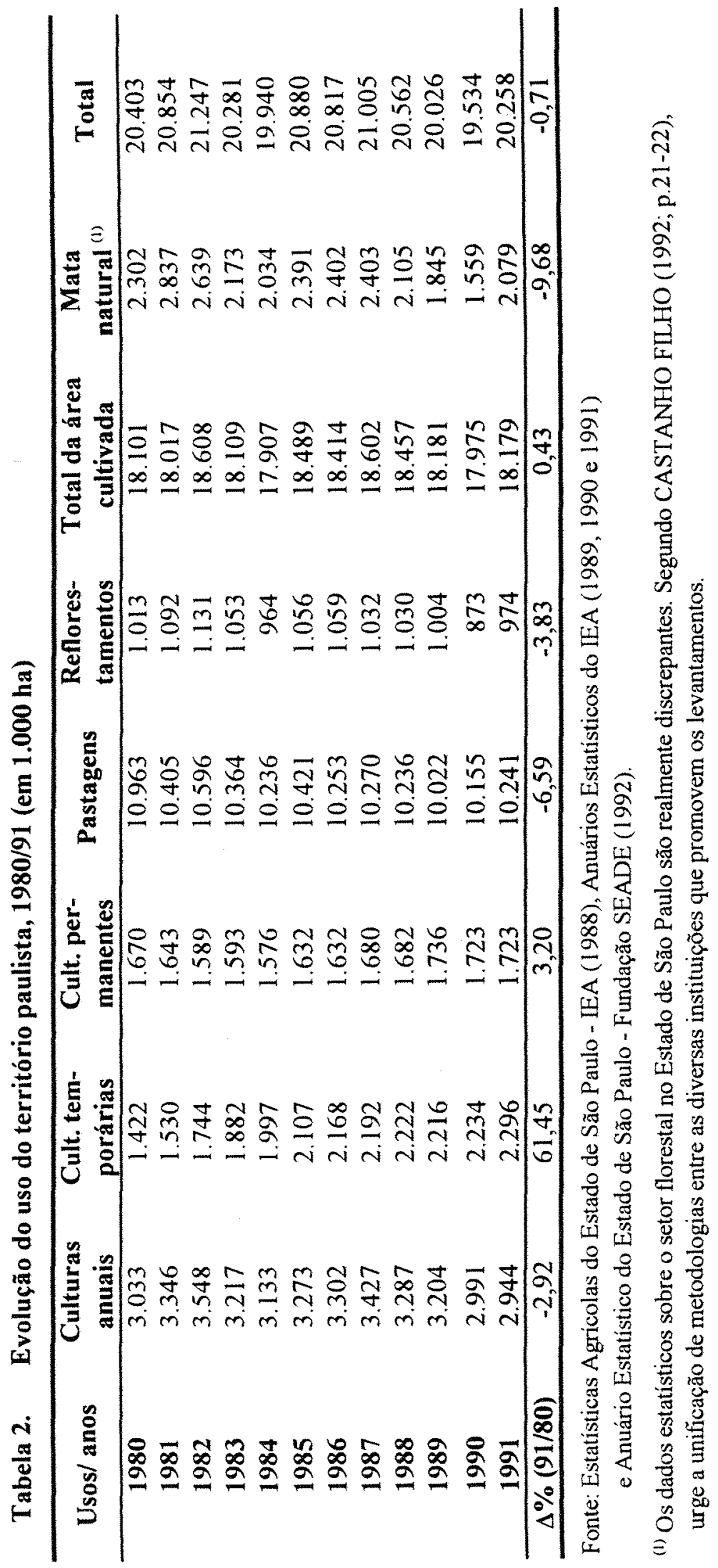


Tabela 3. Taxas médias de perda de solo por erosão, em t/ha/ano, nas principais culturas do Estado de São Paulo.

\begin{tabular}{|c|c|c|c|c|c|}
\hline \multicolumn{2}{|c|}{ culturas anuais } & \multicolumn{2}{|c|}{ culturas temporárias } & \multirow{5}{*}{$\begin{array}{l}\text { Pastagens } \\
\text { Floresta Natural } \\
\text { Reflorestamento }\end{array}$} & \multirow{5}{*}{$\begin{array}{r}0,4 \\
0,004 \\
0,04\end{array}$} \\
\hline Algodão & 24,8 & Cana & 12,4 & & \\
\hline Amendoim & 26,7 & Mamona & 41,5 & & \\
\hline Arroz & 25,1 & Mandioca & 33,9 & & \\
\hline Batata & 18,4 & & & & \\
\hline Cebola & 17,5 & \multicolumn{2}{|c|}{ culturas permanentes } & \multicolumn{2}{|l|}{ outros usos } \\
\hline Feijão & 38,1 & Banana & 0,9 & Outras & 25,0 \\
\hline Milho & 12,0 & Café & 0,9 & & \\
\hline Soja & 20,1 & Laranja & 0,9 & & \\
\hline Trigo & 10,0 & Outras & 0,9 & & \\
\hline Outras & 24,1 & & & & \\
\hline
\end{tabular}

Fonte: BELLINAZZI JUNIOR et al. (1981)

adotadas. A obtenção das estimativas para os outros anos foi feita segundo apenas a variação na ocupação da área pelas culturas, assumindo-se que, ao longo do periodo de doze anos, as outras variáveis da EUPS permaneceram constantes.

A partir dos dados acima, sobre a evolução da área cultivada com as diversas culturas anuais, perenes, pastagens, matas e reflorestamento, estima-se a quantidade de solo perdida no ano (ver tabela 4 e apêndice 4), segundo o uso agrícola do solo. Apesar das fortes alterações observadas no uso do solo ao longo do período estudado, as perdas agropecuárias para o estado mantiveram-se, em média, próximas a 97 milhões de toneladas/ano.

As perdas de solo não são apenas físicas. O solo possui uma fertilidade natural , restrita basicamente às camadas mais superficiais de seu perfil (horizontes " $\mathrm{A}$ " $\mathrm{e}$ "B"), que também é perdida junto com as partículas fisicas. A partir dos experimentos de campo, chegaram-se aos teores médios de nitrogênio, fósforo, potássio, cálcio e magné- 
75.

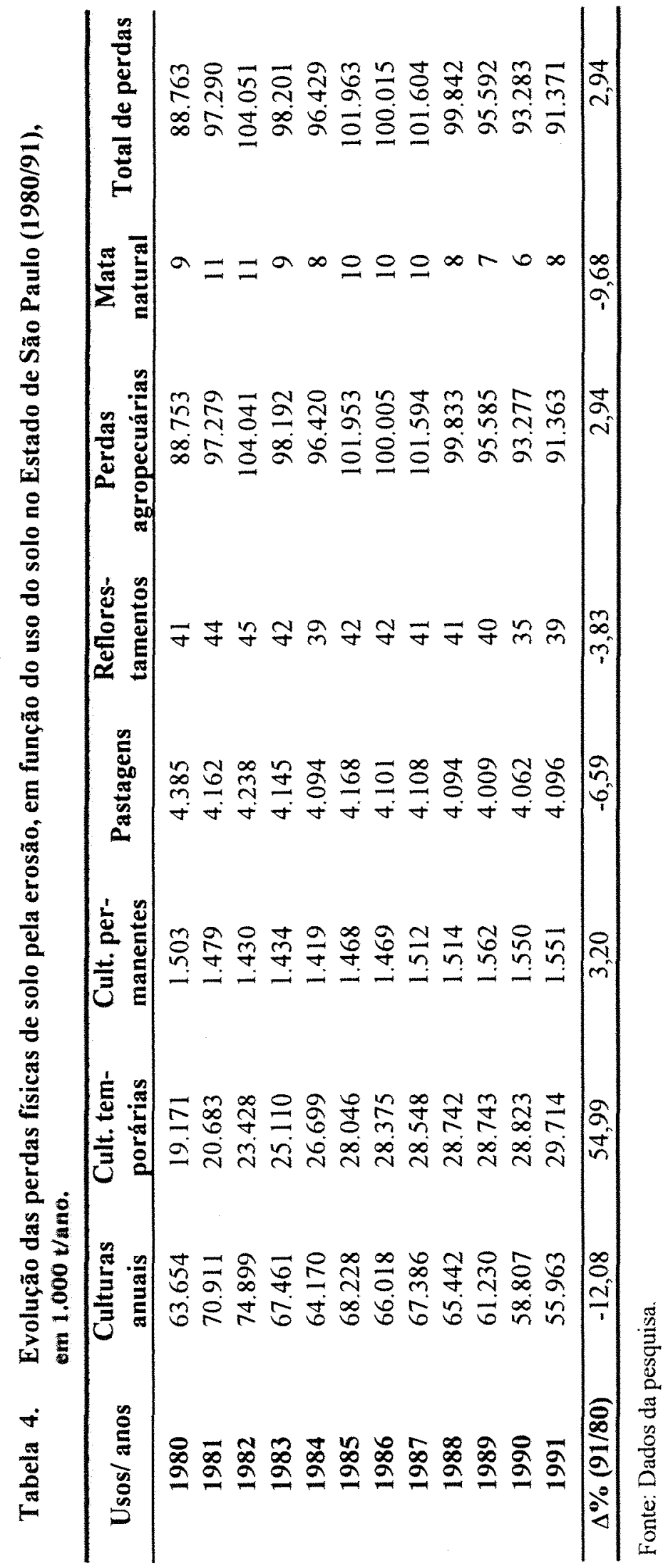


sio, encontrados nos solos paulistas (ver tabela 5).

Tabela 5. Teor médio de nutrientes no solo paulista, em \%

\begin{tabular}{|c|c|c|c|}
\hline $\begin{array}{c}\text { Nitrogênio } \\
(\mathrm{N})\end{array}$ & Fósforo (P) & $\begin{array}{c}\text { Potássio } \\
(\mathrm{K})\end{array}$ & $\begin{array}{c}\text { Cálcio e Magnésio } \\
(\mathrm{Ca}+\mathrm{Mg})\end{array}$ \\
\hline $\mathbf{0 , 0 9 6 7 5}$ & $\mathbf{0 , 0 0 2 6 4 1 4}$ & $\mathbf{0 , 0 1 0 0 5 8}$ & $\mathbf{0 , 0 9 4 8 7 2}$ \\
\hline
\end{tabular}

Fonte: BELLINAZZI JUNIOR et al. (1981)

A partir dos dados compilados de perda de solo por cultura, calcula-se a quantidade de nutrientes perdidos ao longo do periodo proposto para estudo: 1980 a 1991, em termos de nitrogênio, fósforo, potássio e de cálcio e magnésio. Assume-se, dessa forma, que a quantidade tolerável de nutrientes perdidos para os solos paulistas seja nula, ou seja, uma vez perdidos os nutrientes pelo processo erosivo, não seria considerada a capacidade de suporte do solo, havendo a necessidade de repô-los integralmente.

Para o método de valoração foram utilizados os valores de conversão dos nutrientes para equivalentes de fertilizantes comerciais (ver tabela 6), fornecidos

Tabela 6. Valores de conversão e perdas de nutrientes em fertilizantes comerciais.

\begin{tabular}{|cccc|}
\hline Elementos & Fertilizante & $\begin{array}{c}\text { Teor médio } \\
\text { de nutriente }\end{array}$ & $\begin{array}{c}\text { kg de fertilizantes por } \\
\text { kg de nutriente perdido }\end{array}$ \\
\hline $\mathbf{N}$ & Sulfato de Amônia & $20 \%$ & 5.00 \\
$\mathbf{P}$ & Superfosfato Simples & $18 \%$ & 5.56 \\
$\mathbf{K}$ & Cloreto de Potássio & $58 \%$ & 1.72 \\
Ca + Mg & Calcário Dolomítico & $38 \%$ & 2.63 \\
\hline
\end{tabular}

Fonte: BELLINAZZI JUNIOR et al. (1981) 
pelos fabricantes, daqueles mais utilizados no Estado de São Paulo: sulfato de amônio, superfosfato simples, cloreto de potássio e calcário dolomítico. A variável $\mathbf{Q N}_{\text {tot }}$ é então determinada (ver tabela 7).

A variável $\mathbf{P}_{\boldsymbol{f}}$, o preço de mercado do fertilizante, foi obtida junto ao Instituto de Economia Agrícola, a partir de uma série de preços mensais para o insumo, posto em São Paulo. As médias anuais em valores constantes dos preços pagos pelo produtor foram obtidas utilizando-se o Índice Geral de Preços - Disponibilidade Interna, da Fundação Getúlio Vargas, e posteriormente convertidos em dólares médios de 1991 (tabela 8 e apêndices $5 \mathrm{a}-\mathrm{b}$ e 6 ).

Obteve-se o custo de aplicação por unidade de peso de fertilizante e de corretivo $\left(\mathbf{C}_{f}\right)$ a partir dos sistemas de produção das principais culturas do Estado de São Paulo, divulgados anualmente pelo Instituto de Economia Agrícola. Constata-se, ao longo do periodo estudado, uma significativa diminuição dos custos de aplicação de fertilizantes por unidade de peso, explicada basicamente pela incorporação de novas tecnologias, bem como pelo aumento na quantidade utilizada de fertilizante por hectare (ver tabelas 9 e 10 e apêndices 7a-b). A drástica redução no custo de aplicação dos fertilizantes em pastagens consiste na mudança da utilização de maquinário, passando de trator de esteira para trator de rodas.

Tendo sido determinadas as variáveis $\mathbf{Q N}_{\text {tot }}, \mathbf{P}_{\mathbf{f}}$ e $\mathbf{C}_{\mathbf{f}}$, obtém-se, a partir da equação proposta (ver equação 8), uma série de estimativas monetárias referentes ao valor da degradação do recurso solo, em equivalente de fertilizantes 


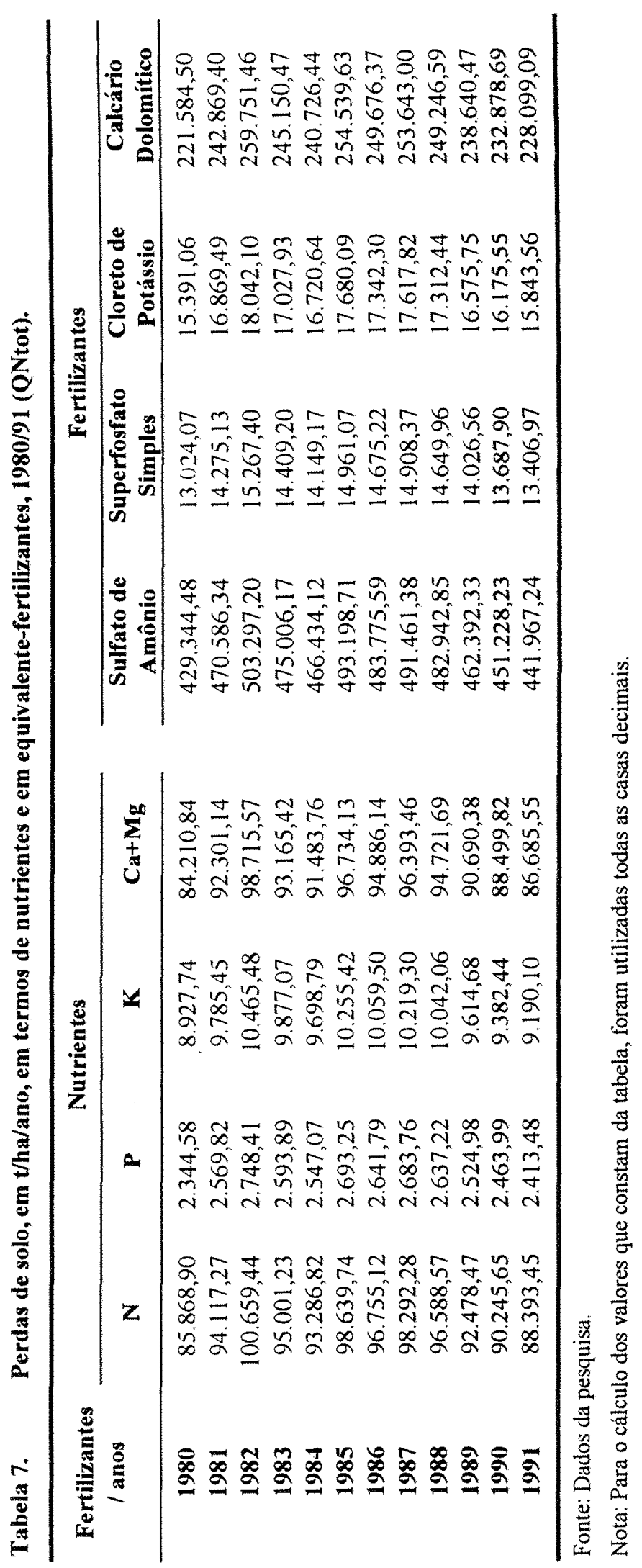


79.

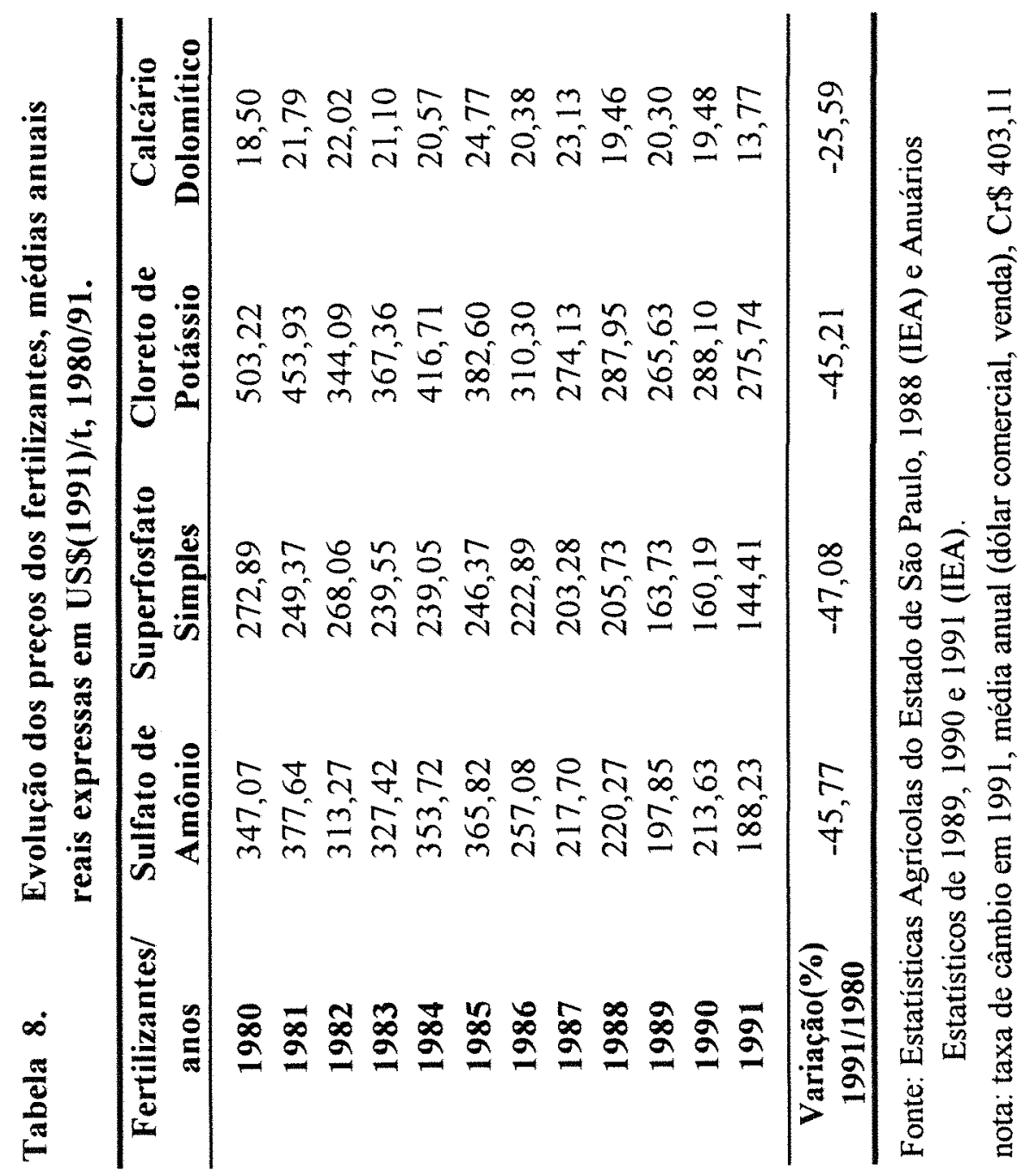


Tabela 9. Custos médios anuais reais de aplicação de fertilizantes, segundo o uso do solo no Estado de São Paulo, em US\$(1991)/t.

\begin{tabular}{cccccc}
\hline Usos/ anos & $\begin{array}{c}\text { Culturas } \\
\text { anuais }\end{array}$ & $\begin{array}{c}\text { Cult. tem- } \\
\text { porárias }\end{array}$ & $\begin{array}{c}\text { Cult. per- } \\
\text { manentes }\end{array}$ & Pastagens & $\begin{array}{c}\text { Média } \\
\text { ponderada }\end{array}$ \\
\hline $\mathbf{1 9 8 0}$ & 69,56 & 53,23 & 120,68 & 277,55 & 218,15 \\
$\mathbf{1 9 8 1}$ & $\mathbf{8 1 , 2 0}$ & 56,56 & 123,91 & 318,03 & 245,54 \\
$\mathbf{1 9 8 2}$ & 60,88 & 48,85 & 126,92 & 309,87 & 233,18 \\
$\mathbf{1 9 8 3}$ & 65,33 & 47,16 & 138,93 & 329,89 & 246,69 \\
$\mathbf{1 9 8 4}$ & 65,78 & 47,66 & 137,62 & 288,78 & 217,64 \\
$\mathbf{1 9 8 5}$ & 60,22 & 28,98 & 132,74 & 348,56 & 254,25 \\
$\mathbf{1 9 8 6}$ & 41,95 & 36,15 & 84,97 & 243,38 & 177,43 \\
$\mathbf{1 9 8 7}$ & 44,02 & 31,72 & 85,07 & 43,56 & 45,72 \\
$\mathbf{1 9 8 8}$ & 47,32 & 34,88 & 81,43 & 43,56 & 46,32 \\
$\mathbf{1 9 8 9}$ & 33,93 & 27,75 & 71,08 & 43,58 & 42,67 \\
$\mathbf{1 9 9 0}$ & 35,23 & 13,92 & 67,72 & 44,15 & 41,40 \\
$\mathbf{1 9 9 1}$ & 40,12 & 20,94 & 65,55 & 43,78 & 42,51 \\
\hline
\end{tabular}

Fonte: Informações Econômicas (IEA), elaborado pelo autor.

(1) ponderação feita pela área.

Tabela 10. Custos médios anuais reais de aplicação de calcário, segundo o uso do solo no Estado de São Paulo, em US\$(1991)/t.

\begin{tabular}{cccccc}
\hline Usos/ anos & $\begin{array}{c}\text { Culturas } \\
\text { anuais }\end{array}$ & $\begin{array}{c}\text { Cult. tem- } \\
\text { porárias }\end{array}$ & $\begin{array}{c}\text { Cult. per- } \\
\text { manentes }\end{array}$ & Pastagens & $\begin{array}{c}\text { Média } \\
\text { ponderada (1) }\end{array}$ \\
\hline $\mathbf{1 9 8 0}$ & 5,18 & 4,54 & 6,91 & n.d. & 5,50 \\
$\mathbf{1 9 8 1}$ & 5,45 & 4,86 & 7,21 & n.d. & 5,76 \\
$\mathbf{1 9 8 2}$ & 6,53 & 5,11 & 7,72 & n.d. & 6,45 \\
$\mathbf{1 9 8 3}$ & 7,27 & 5,50 & 8,67 & n.d. & 7,10 \\
$\mathbf{1 9 8 4}$ & 7,94 & 6,18 & 9,02 & n.d. & 7,67 \\
$\mathbf{1 9 8 5}$ & 6,96 & 4,10 & 8,86 & n.d. & 6,55 \\
$\mathbf{1 9 8 6}$ & 4,57 & 4,54 & 2,88 & n.d. & 4,17 \\
$\mathbf{1 9 8 7}$ & 5,01 & 4,03 & 3,06 & n.d. & 4,27 \\
$\mathbf{1 9 8 8}$ & 6,13 & 4,23 & 3,43 & n.d. & 4,91 \\
$\mathbf{1 9 8 9}$ & 7,32 & 4,53 & 3,11 & n.d. & 5,43 \\
$\mathbf{1 9 9 0}$ & 7,00 & 4,46 & 1,66 & n.d. & 4,86 \\
$\mathbf{1 9 9 1}$ & $\mathbf{8 , 0 9}$ & 4,59 & 3,91 & n.d. & 5,90 \\
\hline
\end{tabular}

Fonte: Informações Econômicas (IEA), elaborado pelo autor.

(1) ponderação feita pela área.

n.d. - não disponivel 
comerciais, o VDS (ver tabela 11 e apêndice 8). Nessas estimativas, considerou-se o custo de aplicação dos fertilizantes, sendo computados os gastos com mão-de-obra e com maquinário.

As perdas médias estimadas foram de US\$176 milhões/ano. Esses resultados, apesar de próximos aos encontrados por BELLINAZZI et al. (1981) e MARTIN et al. (1991), de aproximadamente US\$ 200 milhões/ano, apresentam diferenças metodológicas expressivas. Nestes dois últimos trabalhos, os gastos com a aplicação dos fertilizantes não foram contabilizados e as estimativas são referentes ao valor das perdas do solo para todo o Estado de São Paulo, incluindo as áreas urbanas. No presente estudo, os valores referem-se somente às áreas ocupadas com atividades agricolas, pecuárias e florestais, o que conduz a um resultado que possa ser melhor comparado à renda gerada pelo recurso solo (simplificadamente poderia ser representada pelo próprio PIB agropecuário paulista).

As estimativas monetárias médias da depreciação do recurso solo pelo seu uso, por unidades de área (ver tabela 12), representam o quanto o produtor deveria acrescentar de fertilizantes em suas culturas para compensar a perda de nutrientes devido à erosão do solo. Ou seja, seria o equivalente a incorporar esse valor nas planilhas de custo de produção das culturas anuais plantadas no Estado de São Paulo, a título de manutenção do estoque de capital, natural e produzido, intacto.

Esse valor é mais alto nas culturas anuais, em média US\$ $36,50 /$ ha/ano (aproximadamente o custo por hectare para a construção de terraços de base larga, alugando-se os equipamentos por US $\$ 37,00 /$ ha, segundo estimativa da AEASP(1993)), 


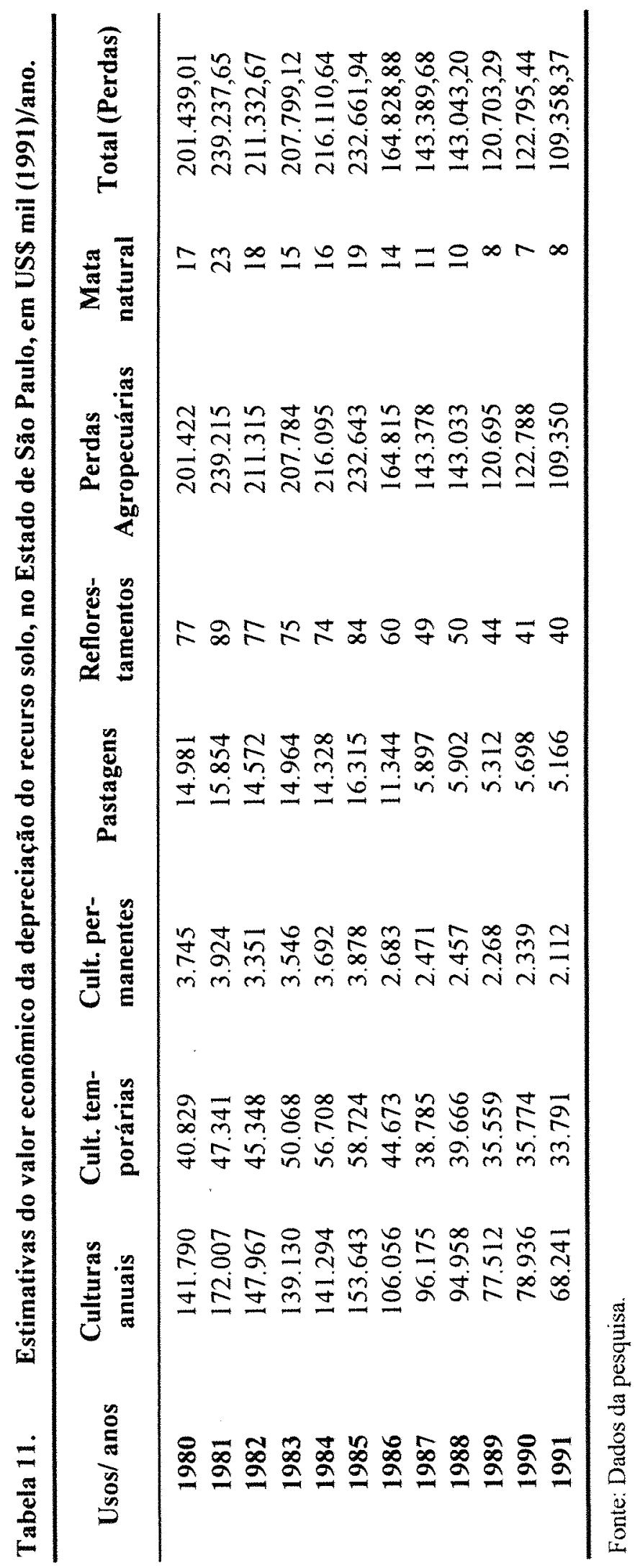




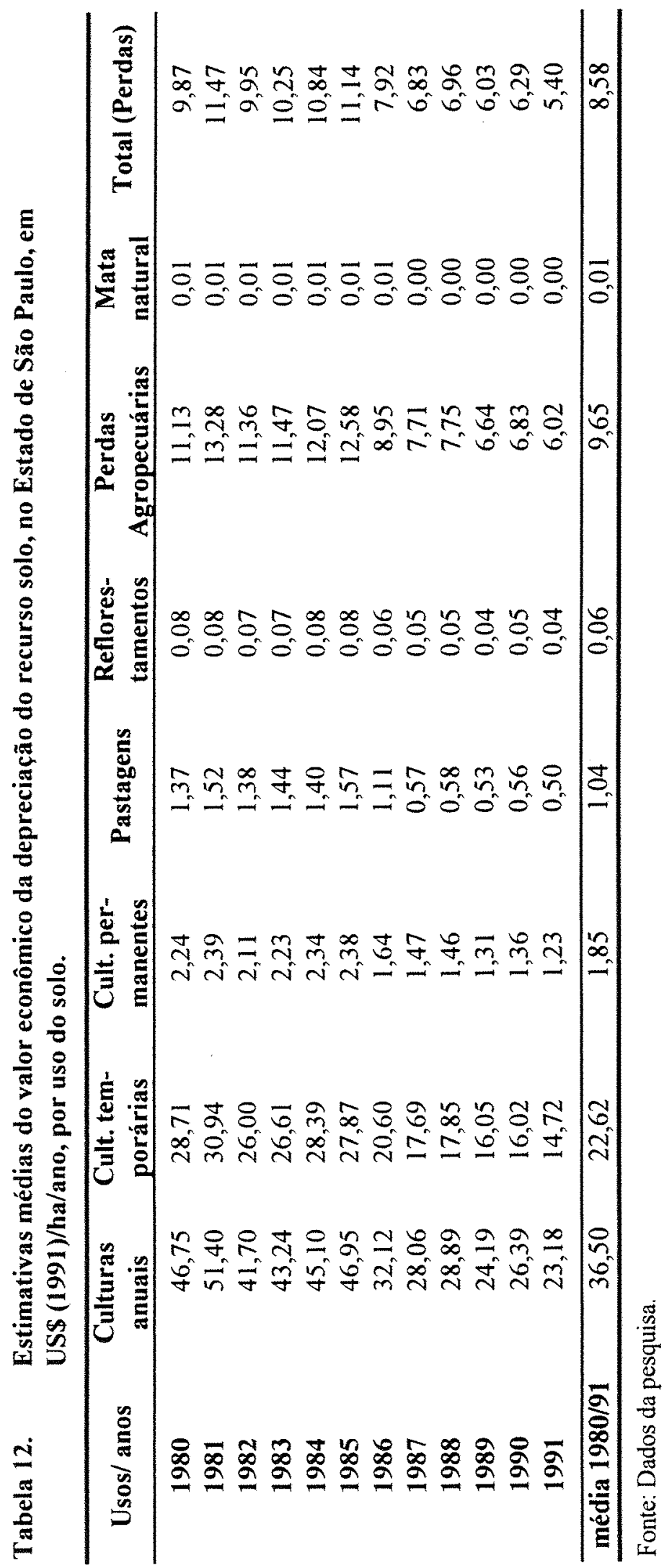


pelo fato de essas culturas promoverem menor cobertura do solo, além de implicarem uma movimentação mais freqüente de maquinário para a realização das operações agrícolas (aração, gradagem, subsolagem, tratos fitossanitários e colheita).

Diante das limitações dos dados disponiveis, algumas observações com relação aos procedimentos adotados no presente estudo devem ser feitas, objetivando inclusive dar uma orientação para futuras reestimativas, à medida que os dados técnicos necessários para se obterem estimativas mais precisas estejam disponiveis.

Primeiro, assume-se que a degradação do solo resume-se à perda de nutrientes (especificadamente, nitrogênio, potássio, fósforo, cálcio e magnésio), não levando em conta problemas de compactação de solo, perda de recursos biológicos, nem a perda de capacidade de retenção de água. A inobservância desses pontos decorre da inexistência de dados técnicos suficientes, bem como de metodologias apropriadas para valorá-los. A migração dos estudos do efeito da erosão do solo, a partir da utilização da Equação Universal de Perda do Solo (EUPS) para outros modelos mais dinâmicos, como o EPIC e o WEPP, resultará em dados mais ricos para as posteriores estimativas monetárias da depreciação do recurso solo.

Segundo, ao se desconsiderar $\mathbf{Q N}_{\text {tol }}$, assume-se que, pela utilização apenas de fertilizantes, é possível recuperar a capacidade produtiva de determinado solo. Em verdade, ultrapassando-se o limite de tolerância de um solo, sua capacidade regenerativa é comprometida e o custo econômico de se manterem os anteriores níveis de 
produtividade passa a ser inviável ${ }^{36}$. Essa hipótese considera que há uma perfeita substituibilidade entre o capital natural e o capital material. Ou seja, é o cenário que MOTTA (1995, p.24) traça como sendo de fraca sustentabilidade, onde "existe a possibilidade tecnológica de crescimento contínuo, desde que a parte da renda econômica seja reinvestida de forma a manter o nível total de capital - natural e material - de uma economia". Em se tratando de um cenário de sustentabilidade forte, os valores encontrados seriam bem maiores, uma vez que uma série de técnicas teria de ser adotada visando manter o nivel de estoque do capital natural.

Terceiro, as perdas médias de solo por cultura, calculadas por BELLINAZZI JUNIOR et al., a rigor, somente seriam válidas para o período em que foram estimadas, ou seja, 1981. Variáveis como distribuição espacial das culturas, manejo do solo e precipitação mudam a cada ano, o que resultaria em diferentes estimativas de perda médias de solo ano a ano.

Uma forma de estimar estes coeficientes periodicamente seria através de fotos por satélite e superposição de mapas de solo, declividade, associando-se dados de manejo das culturas e precipitações registradas nas estações meteorológicas oficiais. As limitações para que o suporte desta tecnologia viesse a dar resultados residem na falta de um mapeamento detalhado dos solos, bem como estudos para interpretar as bandas espectrofotométricas das fotos-satélite para cada cultura. Esta possibilidade, entretanto,

\footnotetext{
${ }^{36}$ Poderíamos imaginar um caso extremo do cultivo morro abaixo em solos litólicos (com profundidade efetiva muito reduzida). em que o processo de erosão expusesse a rocha matriz. inviabilizando a continuidade do cultivo de determinada cultura. Para contornar o problema, o cultivo sob o regime de hidroponia poderia substituir o papel do solo em fornecer sustentação e nutrientes às culturas sobre ele desenvolvidas. Esta drástica mudança tecnológica envolve elevados custos econômicos. muitas vezes incompatívcis com o nível de vida do agricultor, bem como seu grau de instrução.
} 
86.

não é muito remota, uma vez que estudos de mapeamento de solos para a escala 1:25.000 vêm sendo conduzidos e o Sistema de Informações Geográficas (SIG) é cada vez mais utilizado em diversos pontos do território paulista.

Os SIG's constituem-se numa poderosa ferramenta para auxiliar os trabalhos integrados sobre meio ambiente, permitindo que sejam feitas análises sobre as inter-relações entre os diversos componentes do meio ambiente e os fenômenos que nele ocorrem (CAMARA, 1992). O sistema integra, em uma só base de dados, informações espaciais (provenientes de dados cartográficos, mapas digitalizados), levantamentos de censo, imagens de satélite, bem como dados sócio-econômicos pesquisados em nível de campo. O que representa, portanto, um expressivo conjunto de informações capaz de ser manipulado para as mais diversas aplicações na área ambiental (dentre esses, os estudos sobre contabilidade ambiental).

\subsection{O ajuste ambiental do PIB agropecuário paulista}

Uma vez obtidas as estimativas monetárias, efetua-se o desconto na medida da renda agregada da agricultura paulista representada pelo seu Produto Interno Bruto setorial, o PIB Agropecuário. Segundo EL SERAFY (1992, p.11), “a erosão do solo encontra-se na mesma categoria do recurso natural cuja depleção pode ser compensada pela restauração (reposição), e o custo de restauração deverá ser descontado do produto interno do solo para se obter uma verdadeira estimativa do produto líquido".

O PIB agropecuário de São Paulo, de certa forma, pode ser 
considerado como a medida que representa o produto bruto do solo ${ }^{37}$. Segundo a literatura, o ajuste ambiental, ou depreciação do capital natural, deveria ser efetuado sobre as medidas do PIL, onde já estaria descontado o valor da depreciação do capital natural. No entanto, MOLDAU $(1992$, p.96), em estudo feito sobre o estado da arte dos agregados macroeconômicos no Estado de São Paulo, ressalta que não há estimativas nacionais ou estaduais do $\mathrm{PIL}^{38}$.

Sendo assim, e conhecendo essas limitações, a inexistência ou falta de metodologia para se determinar o PIL conduzirá a que o ajuste ambiental seja feito sobre o PIB, indicador este mais utilizado em análises macroeconômicas, obtendo-se um produto bruto ajustado ambientalmente, o PIBenv (ver tabela 13).

Durante o período estudado, a estimativa de depreciação do recurso solo variou de $2,03 \%$ a $5,23 \%$ do PIB agropecuário paulista (ver figura 5). No entanto há uma nítida tendência de queda no valores monetários da degradação do recurso. Esta distorção, causada basicamente pela queda em termos reais dos preços dos insumos (ver tabela 8), constitui alvo da grande parte das críticas referentes à valoração monetária dos recursos naturais e ambientais. A degradação ambiental fica mascarada e sujeita às variações dos preços de mercado dos produtos utilizados para a valoração indireta, en-

${ }^{37}$ Segundo a Fundação SEADE. o produto interno bruto é calculado segundo as atividades básicas classificadas cm:

- agropecuária (culturas permanentes. temporárias. horticultura e floricultura, extração vegetal, pecuária. produtos de origem animal e outras atividades)

- silvicultura

- pesca

- serviços auxiliares à agricultura

Fonte: SEADE (s.d.)

${ }^{38}$ Quando o SCN ainda era calculado pela Fundação Getulio Vargas, a depreciação do capital produzido era calculada como sendo $5 \%$ do valor do PIB. 
Tabela 13. O PIB agropecuário do Estado de São Paulo ajustado ambientalmente (em US\$/1991).

\begin{tabular}{llcccc}
\hline & $\begin{array}{c}\text { PIB agropecuário } \\
\text { de São Paulo }\end{array}$ & $\begin{array}{c}\text { Depreciação do } \\
\text { recurso solo }\end{array}$ & $\begin{array}{c}\text { PIB agropec. } \\
\text { ajustado } \\
\text { ambientalmente } \\
\text { (PIB env) }\end{array}$ & $\begin{array}{c}\text { \% depreciação } \\
\text { em relação ao }\end{array}$ & PIB \\
\hline 1980 & $4.121 .614,15$ & $201.439,01$ & $3.920 .175,14$ & 4,89 \\
1981 & $4.572 .782,97$ & $239.237,65$ & $4.333 .545,32$ & 5,23 \\
1982 & $4.621 .793,68$ & $211.332,67$ & $4.410 .461,01$ & 4,57 \\
1983 & $4.946 .613,47$ & $207.799,12$ & $4.738 .814,35$ & 4,20 \\
1984 & $4.818 .862,42$ & $216.110,64$ & $4.602 .751,77$ & 4,48 \\
1985 & $5.368 .279,71$ & $232.661,94$ & $5.135 .617,77$ & 4,33 \\
1986 & $4.639 .099,21$ & $164.828,88$ & $4.474 .270,33$ & 3,55 \\
1987 & $5.739 .858,00$ & $143.389,68$ & $5.596 .468,32$ & 2,50 \\
1988 & $5.083 .946,84$ & $143.043,20$ & $4.940 .903,64$ & 2,81 \\
1989 & $5.028 .341,29$ & $120.703,29$ & $4.907 .638,01$ & 2,40 \\
1990 & $5.196 .367,24$ & $122.795,44$ & $5.073 .571,81$ & 2,36 \\
1991 & $5.392 .673,99$ & $109.358,37$ & $5.283 .315,62$ & 2,03 \\
\hline & & & & & \\
\hline
\end{tabular}

Fonte: Dados da pesquisa. 
89.

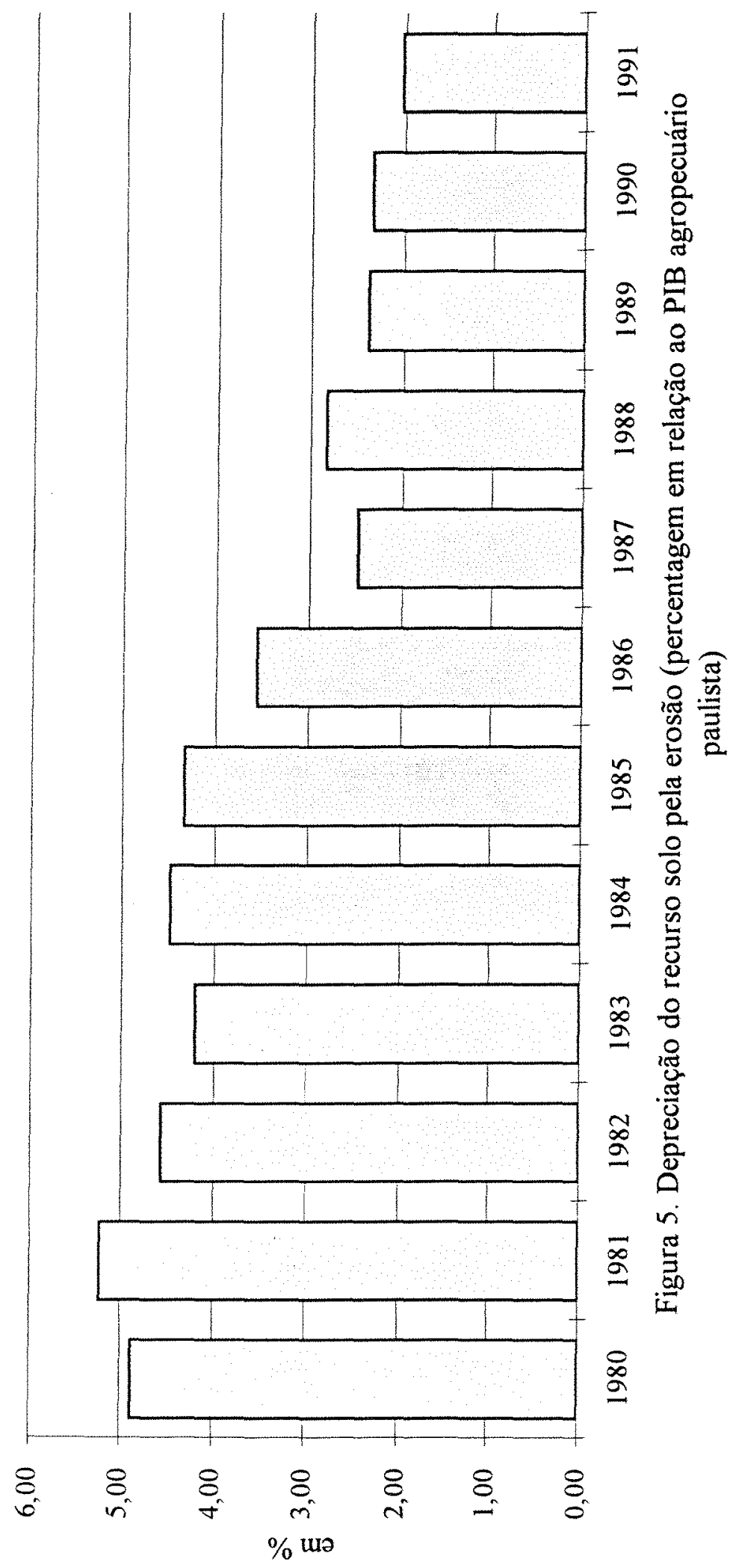


quanto a perda fisica mantém-se relativamente inalterada; a monetária varia de acordo com as flutuações dos preços (ver figura 6). Neste sentido, ressalta-se a importância do desenvolvimento de contas fisicas que captem as variações dos estoques fisicos dos recursos naturais, ou que captem as variações nos padrões de qualidade dos recursos ambientais, a exemplo da experiência francesa de contas patrimoniais (THEYS, 1992).

No trabalho de Solórzano et al., o valor da degradação do solo variou entre $6,5 \%$ a $13,3 \%$ do PIB ao longo do período estudado de quinze anos. Ressalta-se que, nesses estudos, tanto a eficiência da aplicação dos fertilizantes assim como a quantidade tolerável pelos solos foram consideradas. No caso do trabalho de BISHOP \& ALLEN (1989), a determinação dos custos da erosão do solo nas propriedades agrícolas de Mali (on-site costs) revelou que o montante médio anual perdido responde por 4 a $16 \%$ do PIB agrícola. Já o valor da degradação do solo na Iha de Java, segundo estudo feito por MAGRATH \& ARENS (1989), chegou a representar 5\% do PIB total.

Nos trabalhos de contabilidade ambiental, deve estar muito claro que, conforme abordado por FAETH (1995, p.26), a exclusão por si só dos custos da degradação dos recursos das medidas agregadas do produto agrícola não será condição suficiente para a solução do problema ambiental. O valor é uma aproximação, muito tênue, dos gastos que deveriam ser feitos em prol do ambiente. No entanto, a forma como esses dispêndios, normalmente efetuados pelo governo, serão feitos podem levar os tomadores de decisão a adotar péssimas politicas e os fazendeiros, péssimas práticas. Ou seja, o repasse única e exclusivamente de impostos para a agricultura, no montante equi- 
91.

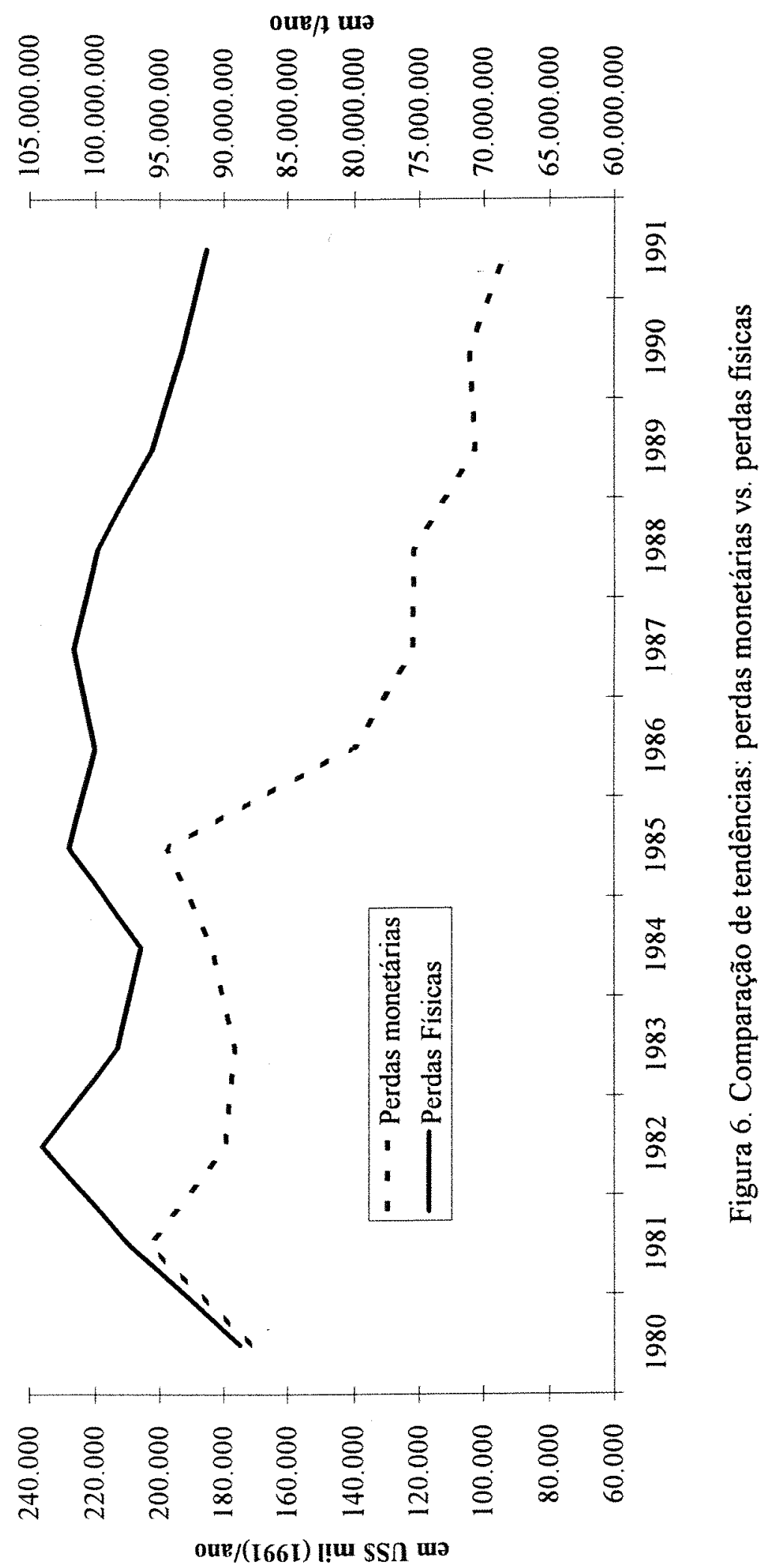


valente à depreciação do recurso solo, através de programas de incentivo à conservação do solo e crédito subsidiado, gerará distorções que levarão sempre ao uso ineficiente dos recursos. A alternativa é justamente conceder opções ao produtor a fim de que ele possa escolher as formas mais adequadas ao seu modo de produzir e que, ao mesmo tempo, sejam o mais possivel benignas ao ambiente (FAETH, 1995, p. 105). 
93.

\section{CONCLUSÕES}

A introdução do capital natural no sistema de contabilidade social permite mensurar o quão distanciada encontra-se a economia com relação à capacidade de consumir a renda líquida, sem que haja um empobrecimento na base dos recursos naturais. Para o caso do Estado de São Paulo, a pesquisa indica que a depreciação do recurso solo variou de 2,03 a $5,23 \%$, em relação ao produto bruto gerado pelo setor agropecuário, ao longo desses doze anos. Para que a capacidade produtiva do solo fosse mantida, deveria haver, grosso modo, uma reposição de nutrientes equivalente aos US\$ 176 milhões/ano perdidos em função da erosão. Uma alternativa, bem menos onerosa, seria a implementação de programas que visassem estimular os produtores a adotar práticas conservacionistas.

O valor encontrado pelo estudo é sem dúvida um limite inferior. Foram mensurados apenas os chamados custos internos da erosão (on-site costs). Embora não existam dados disponíveis para um estudo detalhado dos custos externos da erosão do solo (off-site costs), trabalhos em outros países indicam que esse valor é ainda maior que os custos mensurados dentro da propriedade agrícola.

Os números, ou valores estimados, pelos estudos de contabilidade ambiental, por sua vez, não podem e não devem ser considerados como o ponto final de 
todo um trabalho. Decorrem desses estudos sugestões de aprimoramento da pesquisa, bem como subsidios para a formulação de políticas ambientais, mais especificamente para as políticas voltadas ao combate da erosão do solo.

Por outro lado, a falta crônica de dados estatísticos suficientes para o desenvolvimento de contas ambientais, tanto em nível de estado como de país, não significa que se deva esperar o aprimoramento desses dados para dar continuidade aos trabalhos de valoração. A implementação de um sistema de contabilidade natural precisa ser feita por etapas, começando a partir da simples identificação das variáveis ambientais mais restritivas, passando pela organização do sistema de alimentação dos dados básicos, pela construção das contas propriamente ditas e chegando ao ponto em que estudos macroeconômicos voltados para o impacto ambiental sejam conduzidos, procurando evidenciar, dessa forma, as ligações entre o meio ambiente e o sistema econômico.

O sucesso desse esforço de construção das contas ambientais, no entanto, depende da existência de vontade e necessidade política, assim como da bem sucedida ligação estabelecida entre governo, cientistas, economistas, planejadores e estatísticos. Para o andamento dos estudos sobre o ambiente, essa integração entre técnicos das mais diversas áreas é fundamental. Ferramentas, como por exemplo, os Sistemas de Informações Geográficas, possuem amplo potencial de utilização e geração de informações, desde que haja uma integração entre as equipes que levantam e alimentam as bases de dados.

Como exemplo, diversos trabalhos dessa natureza vêm sendo desenvolvidos no Estado de São Paulo: a digitalização de mapas fisiográficos, a 
realização de levantamentos de solo em escala mais reduzida, os levantamentos por satélite do uso do solo (visando previsão de safras, controle do desmatamento, etc), bem como a continuidade dos estudos sobre os impactos da erosão sobre o solo cultivado e para fora das unidades produtivas (problemas de sedimentação, contaminação dos cursos d'água, etc). Trabalhos cujos resultados, após reunidos, poderão contribuir para o estabelecimento de um sistema contábil ambiental nesse Estado.

As estimativas da depreciação do recurso solo, segundo os custos internos da erosão, poderiam ser mais acuradas se pesquisas fossem desenvolvidas com o intuito de se chegar aos seguintes dados:

- relações entre perda de solo e perda de produtividade, de acordo com o tipo de solo, declividade e a cultura cultivada;

- reavaliação periódica dos coeficientes da equação de perda de solo;

- percentagem de sedimentos carreados pela erosão e que, efetivamente, são depositados nos cursos d'água;

- determinação dos limites de tolerância de perda por classes de solo no território paulista; e,

- alterações observadas na biota do solo em função do processo erosivo.

Para justificar essas análises bem como para sensibilizar a necessidade de se promover uma ação efetiva sobre o controle da erosão do solo pelo seu uso agrícola no Estado de São Paulo, alguns estudos que visariam à obtenção das estimativas dos custos causados pela erosão fora da unidade produtiva (os off-site costs), seriam 
também necessários, como por exemplo:

- avaliação do impacto da sedimentação sobre a redução da vida útil das represas que servem ao tratamento de água para o consumo urbano e para a geração de energia elétrica;

- determinação do impacto dos produtos carreados pelo processo erosivo (sedimentos, produtos químicos e orgânicos) na flora e fauna aquáticas;

- determinação do impacto da erosão sobre os custos de tratamento da água para consumo urbano (em termos de aquisição de novos equipamentos e novos produtos para tratamento ou novas dosagens, tendo em vista o problema da eutrofização das águas; e na estimativa da redução na vida útil dos equipamentos já existentes pelo desgaste abrasivo dos sedimentos e pela corrosão química);

- determinação do impacto dos sedimentos na geração de energia hidroelétrica (redução da vida útil dos equipamentos pelo desgaste abrasivo com a passagem de sedimentos, da freqüência de dragagem, etc);

- identificação dos corpos d'água que possuem finalidade recreativa, como represas, lagos e rios, e avaliação da redução de bem-estar da população usuária pela contaminação destes corpos, especialmente no que se refere ao assoreamento e à eutrofização;

- identificação e quantificação, fisicamente, dos danos causados pelas inundações em municípios, em função da deposição de sedimentos nos corpos d'água; e, finalmente;

- determinar a percentagem de contribuição da agricultura ao assoreamento e 
poluição dos mananciais hídricos (utilização de marcação dos solos de experimentos com isótopos radioativos).

Do ponto de vista da necessidade de formulação de politicas específicas para o combate da erosão do solo, há suspeitas que o produtor não perceba a perda média anual referente aos US\$176 milhões estimados. Apesar de ser um valor elevado, a não adoção de práticas conservacionistas parece não ser inconsistente com a racionalidade econômica do produtor. Dois pontos corroboram para essa afirmação: primeiro, é observada uma queda real no preço dos insumos agrícolas, portanto a aplicação de uma maior quantidade de fertilizantes para compensar a perda de produtividade em função da erosão não impactaria significativamente os custos de produção; segundo, a relação entre erosão e perda da produtividade das culturas não é tão critica no Brasil devido ao nossos solos profundos. Desta forma, no curto prazo, os agricultores não estariam percebendo a degradação do recurso solo causada pela erosão.

A importância das estimativas do impacto da erosão para fora da unidade produtiva reside justamente no ponto acima. O principal fator de produção da agricultura está sendo depreciado e os produtores não parecem perceber esta perda. Além disso, externalidades negativas geradas pela erosão provocam perdas monetárias tão ou mais significativas que os prejuizos sobre a propriedade agrícola. Ainda, há prejuizos incalculáveis, como os referentes à perda da biota do solo e às alterações da flora e fauna aquáticas.

Diante da gravidade desses problemas ambientais, urge a 
implementação de ações que visem reduzir a erosão do solo, principalmente nas áreas agrícolas. No caso do Estado de São Paulo, o Projeto de Microbacias Hidrográficas, realizado com contrapartidas financeiras do Estado e do Banco Mundial, está, há mais de cinco anos, tentando contornar o problema da erosão do solo de uma forma integrada. Até 1994, foram gastos US\$ 46 milhões com o programa ${ }^{39}$. Vale ressaltar que a compensação da depreciação do recurso natural não requer, necessariamente, a aplicação de um montante de igual valor em programas de recuperação ambiental. Um programa eficiente resolve os problemas ambientais com o mínimo de gastos. A utilização de instrumentos econômicos em conjunto com os já bastante utilizados instrumentos de comando e controle, é uma combinação que a literatura atual prescreve como uma das mais eficientes em termos de minimização de custos e maximização de resultados.

Um exemplo ilustrativo do funcionamento de um instrumento de mercado seria o de promover um aumento do preço dos insumos (através de taxações, por exemplo). Num modelo de equilibrio parcial, partindo do pressuposto que há um significativo grau de substituibilidade entre capital natural (solo) e insumos, produtores racionais passariam, em função da elevação do preço dos insumos, a adotar técnicas poupadoras do recurso solo (uma vez que a degradação do solo levaria a quedas na produtividade que poderiam ser corrigidas através da aplicação de uma maior quantidade de insumos). Por sinal, algumas dessas práticas já vêm sendo utilizadas, como por exemplo, o Plantio Direto, o Manejo Integrado de Pragas e Doenças, entre outras. Obviamente, esse exemplo de política, utilizado com fins ilustrativos, deixa de considerar

39 Dados fornecidos pela Coordenação do Programa de Microbacias Hidrográficas, da Secretaria de Agricultura e Abastecimento do Estado de São Paulo. 
importantes variáveis como, por exemplo, a taxa de adoção de novas tecnologias pelos produtores e as conseqüências na oferta agregada.

Por outro lado, a pesquisa, a extensão rural e a educação ambiental desempenham papéis primordiais nos estudos dessas alternativas. Destaca-se, desta forma, a necessidade de disseminação das informações sobre essas formas de produção como complemento ao instrumento de mercado exemplificado, ressaltando-se as vantagens econômicas e ambientais que elas trazem e enfatizando as experiências bemsucedidas de produtores que já as adotam

Com essas últimas considerações, deve estar claro, agora, que o principal objetivo de um sistema de contas ambientais não é o de simplesmente fornecer indicadores de renda ambientalmente ajustados. Esses números não são panacéias para solucionar o problema da degradação ambiental. Se corretamente calculados, podem contribuir não somente no esclarecimento da complexas inter-relações entre o meio ambiente e a economia, mas também podem servir de importante fonte de informação na elaboração e implementação de políticas econômicas e ambientais. 


\section{REFERÊNCIAS BIBLIOGRÁFICAS}

ABLAS, L. Contabilidade econômica do meio ambiente: proposta metodológica para aplicação ao Estado de São Paulo. In: NORZOE, N., coord. Contabilização econômica do meio ambiente: elementos metodológicos e ensaio de aplicação no Estado de São Paulo. São Paulo: Secretaria do Meio Ambiente, 1992. p.97-111 (Série seminários e debates).

AMSTALDEN, L.F.F. Os custos sócio-ambientais da modernização agrícola brasileira Campinas: IFCH/UNICAMP, 1991. (Monografia, 1).

ANGULO FILHO, R.; ELLIOT, W.J.; DECHEN, S.C.F. Erosion prediction for Brazil with the WEPP model. Michigan, American Society of Agricultural Engineers, 1990. (ASAE meeting presentation, paper n.908514).

ANUÁRIO ESTATÍSTICO DO ESTADO DE SÃO PAULO. São Paulo: Fundação Seade, 1992.

ARAÚJO, P.F.C. de. Agricultura no processo de desenvolvimento econômico. In: ARAÚJO, P.F.C. de; SCHUH, G.E. Desenvolvimento da agricultura; natureza do processo e modelos dualistas. São Paulo: Pioneira, 1975. v.1, p.83-97.

ASSOCIAÇÃO DOS ENGENHEIROS AGRÔNOMOS DO ESTADO DE SÃO PAULO. SOS solo. São Paulo, 1993. 19p. 
BARTELMUS, P.; LUTZ, E.; SCHWEINFEST, S. Integrated environmental and economic accounting: a case study for Papua New Guinea. Washington: The World Bank, 1992. (Environmental Working Paper n. 5)

BARTELMUS, P. A contabilidade verde para o desenvolvimento sustentável. In: MAY, P.H.; MOTTA, R., org. Valorando a Natureza: análise econômica para o desenvolvimento sustentável. Rio de Janeiro: Campus, 1994. p.157-75.

BELLINAZZI JUNIOR, R.; BERTOLINI, D.; LOMBARDI NETO, F. A ocorrência de erosão rural no Estado de São Paulo. In: SIMPÓSIO SOBRE O CONTROLE DA EROSÃO, 2., São Paulo, 1981. Anais. São Paulo: ABGE, 1981. p.117-137.

BISHOP, J.; ALLEN, J. The on-site costs of soil erosion in Mali. Washington: The World Bank, 1989. (Environmental Working Paper n. 21)

CABRAL JUNIOR, D. Caracterização da qualidade da água de drenagem de área agrícola: a cultura da batata. In: CONGRESSO BRASILEIRO DE ENGENHARIA SANITÁRIA, 9., São Paulo, 1977. Trabalhos apresentados. São Paulo: CETESB, 1977.

CAIRNCROSS, F. Meio ambiente: custos e beneficios. São Paulo: NOBEL, 1992.

CAMARA, G. Panorama e perspectivas dos sistemas de geoprocessamento no Brasil. São José dos Campos: Insituto Nacional de Pesquisas Espaciais, 1992. 11p. (mimeo.)

CAMARGO FILHO, W.P., coord. Estatísticas de produção agrícola no Estado de São Paulo. São Paulo: Secretaria da Agricultura e Abastecimento. Instituto de Economia Agrícola, 1990. v.1. 
CASTANHO FILHO, E.P. Afinal, qual é a cobertura florestal de São Paulo? Florestar Estatístico, São Paulo, v. 2, n. 6, p. 21-22. nov.1994/fev.1995.

CAVALCANTI, J.E.A. Impacto econômico das perdas de solo no Vale do Rio São Francisco. In: CONGRESSO DE ECONOMIA E SOCIOLOGIA RURAL, 33., Curitiba, 1995. Anais. Brasilia: SOBER, 1995. v.2, p.1097-111.

CLARK II, E.H., HAVERKAMP, J.A.;CHAPMAN, W. Eroding soils: the off-farm impacts. Washington: The Conservation Foundation, 1985.

CUNHA, A.S. Agricultura, recursos naturais e meio ambiente. Agricultura em São Paulo, São Paulo, v.39, n.2, p. 5-15, 1992.

CUNHA, A.S.; MUELLER, C.C.; ALVES, E.R.A.; SILVA, J.E. da. Uma avaliação da sustentabilidade da agricultura nos cerrados. In: IPEA. Estudos de política agrícola. Brasília: IPEA, 1993. p-35-52. (Sumários Executivos, 2)

DALY, HE. Toward a measure of sustainable social net national product. In: AHMAD, Y.J.; EL SERAFY, S.; LUTZ, E., ed. Environmental accounting for sustainable development. 3.ed. Washington: The World Bank, 1992. p.8-9.

DAVID, M.B.A. O papel do estado e do setor privado na estratégia de retomada do crescimento do setor agropecuário. In: IPEA. Perspectivas da economia brasileira 1992. Rio de Janeiro: IPEA, 1991. p.373-84.

DENISON, E.F. Welfare measurement and the GNP. Survey of Current Business, v.51, n. 1,1971 .

DREGNE, H.E. Historical perspective of accelerated erosion and effect on world 
civilization. In: ASA. Determinants of soil loss tolerance. Madison: American Society of Agronomy. Soil Science Society of America, 1982. (Special publication, n. 45)

EL SERAFY, S. The proper calculation of income from depletable natural resources. In: AHMAD, Y.J.; EL SERAFY, S.; LUTZ, E., ed. Environmental accounting for sustainable development. 3.ed. Washington: The World Bank, 1992. p. 10-8.

EL SERAFY, S.; LUTZ, E. Environmental and resource accounting: an overview. In: AHMAD, Y.J.; EL SERAFY, S.; LUTZ, E., ed. Environmental accounting for sustainable development. 3.ed. Washington: The World Bank, 1992. p. 1-7.

FAETH, P. Methods for economic analysis of agricultural sustainability. Geneva: UNCTAD, 1995. (MEETING ON INTERNALIZATION OF ENVIRONMENTAL EXTERNALITIES)

FISHER, A.C. Resource and environmetal economics. New York: Cambridge University Press, 1981.

FONSECA, E.G. da. Meio ambiente e contas nacionais: a experiência internacional. In: NORZOE, N., coord. Contabilização econômica do meio ambiente: elementos metodológicos e ensaio de aplicação no Estado de São Paulo. São Paulo, Secretaria do Meio Ambiente, 1992. p. 29-43. (Série seminários e debates)

FOSTER, G.R. Modeling soil erosion and sediment yield. In: LAL, R. ed. Soil Erosion Research Methods. Iowa: Soil and Water Conservation Society, 1988.

FOY, G.E. Accounting for non-renewable natural resources in Louisiana's gross state product. Ecological Economics, Amsterdam, v.3, n.1, p. 25-41, 1991. 
FUNDAÇÃO INSTITUTO BRASILEIRO DE GEOGRAFIA E ESTATÍSTICA. Brasil: novo sistema de contas nacionais; metodologia e resultados provisórios; ano-base 1980. Rio de Janeiro: FIBGE, 1988. (Texto para discussão, 10)

FUNDAÇÃO SEADE. Produto interno bruto, formação bruta de capital e consumo. Estado de São Paulo: 1975-84. São Paulo: Fundação SEADE, s.d. (Relatório final de pesquisa: convênio IPEA-SEADE).

GOLDIN, I. e REZENDE, G.C. de. A agricultura brasileira na década de 80: crescimento numa economia em crise. Rio de Janeiro: IPEA, 1993. 119p. (Série IPEA, n.138).

GONÇALVES, J.S., coord. Anuário de informações estatísticas da agricultura: anuário IEA 1989. São Paulo: Secretaria da Agricultura e Abastecimento, Instituto de Economia Agrícola, 1990. 1v.

HARRINSON, A. Introducing natural capital into the SNA. In: AHMAD, Y.J.; EL SERAFY, S.; LUTZ, E., ed. Environmental accounting for sustainable development. 3.ed. Washington: The World Bank, 1992. p. 19-25.

HUETING, R.; BOSH, P.; BOER, B. de. Metodologia para o cálculo da renda nacional sustentável. Conjuntura Econômica, Rio de Janeiro, v. 46, n. 6, p. 36-7. jun. 1992.

HUFSCHIMIDT, M.M.; JAMES, D.E.; MEISTER, A.D.; BOWER, B.T.; DIXON, J.A. Environment, natural systems, and development: an economic valuation guide. Baltimore: The Johns Hopkins University Press, 1983.

KRAUSS, H.A.; ALMARRAS, R.R. Technology masks the effects of soil erosion on wheat yields - a case study in Whiteman County, Washington. In: ASA. 
Determinants of soil loss tolerance. Madison: American Society of Agronomy. Soil Science Society of America, 1982. (Special publication, n. 45)

LEFTWICH, R.H. O sistema de preços e a alocação de recursos. 6.ed. São Paulo: Pioneira, 1983. $452 \mathrm{p}$.

LEHWING, M.L.M. A estrutura da produção brasileira à luz das contas nacionais. Conjuntura Econômica, Rio de Janeiro, v.47, n. 1, p. 61-63, jan. 1993.

LUTZ, E.; MUNASINGHE, M.. Contabilizando o meio ambiente. Finanças $e$ Desenvolvimento, Rio de Janeiro, v.11, n.1, p. 19-21, mar. 1991.

LUTZ, E.; SERAFY, S. El. Recent developments and future works. In: AHMAD, Y.J.; EL SERAFY, S.; LUTZ, E., ed. Environmental accounting for sustainable development. 3.ed. Washington: The World Bank, 1992. p. 88-91.

MAGRATH, W.; ARENS, P. The costs of soil ersoion on Java: a natural resource accounting approach. Washington: The World Bank. Sector Policy and Research Staff, 1989. (Environment working paper, n. 18)

MARGULIS, S. Back of the envelope of environmental damage costs in Mexico. Washington: The World Bank, s.d.

MARGULIS, S. Introdução à economia dos recursos naturais. In: MARGULIS, S., ed. Meio ambiente: aspectos técnicos e econômicos. Brasilia: IPEA/PNUD, 1990. p. $157-78$.

MARTIN, Nelson Batista et al. Economia agrícola paulista: características e potencialidades. Informações Econômicas, São Paulo, v.21, p.1-201, jan. 1991 
(Suplemento 01/91)

MENCK, P.C.M. Avaliação econômica do controle da erosão na microbacia do ribeirão Iperó, em Araçoiaba da Serra, Estado de São Paulo. Piracicaba, 1993. Dissertação (Mestrado). Escola Superior de Agricultura "Luiz de Queiroz", Universidade de São Paulo.

MOLDAU, J.H. Os agregados macroeconômicos em São Paulo. In: NORZOE, N., coord. Contabilização econômica do meio ambiente: elementos metodológicos $e$ ensaio de aplicação no Estado de São Paulo. São Paulo: Secretaria do Meio Ambiente, 1992. p.75-96. (Série seminários e debates).

MONTEIRO, M.J.C. Agropecuária nas contas nacionais. Conjuntura Econômica, Rio de Janeiro, v. 47, n. 1, p. 73-75, jan. 1993.

MOTTA, R.S. da. Análise de custo-beneficio do meio ambiente. In: MARGULIS, S., ed. Meio ambiente: aspectos técnicos e econômicos. Brasilia: IPEA/PNUD, 1990. p. 109-34.

Uma proposta metodológica para estimativas de contas ambientais no Brasil. Rio de Janeiro: Instituto de Pesquisa Econômica Aplicada, 1991. (Relatório interno, n. 4)

Estimativas de depreciação de capital natural no Brasil. In: MAY, P., org. Economia Ecológica; aplicações no Brasil. Rio de Janeiro: Campus, 1995. p. $21-48$

MOTTA, R.S. da; MAY, P. H. Loss in forest resource values due to agricultural land conversion in Brazil. Rio de Janeiro: Instituto de Pesquisa Econômica Aplicada, 
1992. (Texto para discussão, n. 248)

MOTTA, R.S. da; MAY, P. H. Contabilizando o consumo de capital natural. In: MAY, P. H.; MOTTA, R.S. da, org. Valorando a natureza: análise econômica para o desenvolvimento sustentável. Rio de Janeiro: Campus, 1994. p. 177-195.

MOTTA, R.S. da; YOUNG, C. E. F. Recursos naturais e contabilidade social: a renda sustentável da extração mineral no Brasil. Rio de Janeiro: Instituto de Pesquisa Econômica Aplicada, 1992. (Texto para discussão, n. 231)

MUELLER, C.C. A dimensĩo ambiental no sistema de contas nacionais. Rio de Janeiro: Fundação Instituto Brasileiro de Geografia e Estatística, 1991. (Textos para discussão, n. 47)

NICHOLLS, W.H. O "excedente agrícola" como fator de desenvolvimento econômico. In: ARAÚJO, P.F.C. de; SCHUH, G.E. Desenvolvimento da agricultura; natureza do processo e modelos dualistas. São Paulo: Pioneira, 1975. v.1, p.3-38.

NORDHAUS, W.D.; TOBIN, J. Measurement of economic welfare. Natural Bureau of Economic Research, 1972. (Fifth Aniversary Colloquium, v.5)

NORGAARD, R.B. Linkages between environmental and national income accounts. In: AHMAD, Y.J.; EL SERAFY, S.; LUTZ, E., ed. Environmental accounting for sustainable development. 3.ed. Washington: The World Bank, 1992. p. 54-58.

PARIS, D.F.; LEWIS, D.L. Chemical and microbial degradation of ten selected pesticides in aquatic systems. Residue Reviews, v.45, p. 95-124, 1973.

PEARCE, D.W.; TURNER, R.K. Measuring environmental damage I; total economic 
value. In: PEARCE, D.W.; TURNER, R.K. Economics of natural resources and the envrionment. Baltimore: The Johns Hopkins University Press, 1990. p.120-40.

PESKIN, H.M.. A proposed environmental accounts framework In: AHMAD, Y.J.; EL SERAFY, S.; LUTZ, E., ed. Environmental accounting for sustainable development. 3.ed. Washington: The World Bank, 1992. p.65-78.

PIMENTEL, D.; PIMENTEL, M. Comment: adverse environmental consequences of the green revolution. In: DAVIS, K.; BERNSTAM, M.S., ed. Resources, environment, and population: present knowledge, future options. Oxford: Oxford University Press, 1991. p.329-332. (Population development review, v. 16 - supplement)

RANDALL, A. Resource economics: an economic approach to natural resource and envrionmental policy. 2.ed. New York: John Willey \& Sons, 1987.434 p.

REPETTO, R.; MAGRATH, W.; WELLS, M.; BEER, C.; ROSSINI, F. Wasting assets: natural resources in the national income accounts. Washington: World Resource Institute, 1989.

SCHMITT, M.R. Operação e manutenção de unidades operacionais de tratamento de água. In: CONGRESSO INTERAMERICANO DE INGENIERIA SANITARIA Y AMBIENTAL, 23., La Habana, Cuba, 1992. Anais.

SCHULTZ, L.A. Métodos de Conservação do Solo. Porto Alegre, Sagra, 1987.

SCHUMM, S.A.; HARVEY, M.D. Natural erosion in the USA. In: ASA. Determinants of soil loss tolerance. Madison: American Society of Agronomy, Soil Science Society of America, 1982. (Special publication, n. 45) 
SIMONSEN, M.H.; CYSNE, R.P. Macroeconomia. Rio de Janeiro: Ao Livro Técnico, 1989.

SILVA, C.A. da. Questionando o Paraná Rural: uma análise do modelo ambiental para a agricultura. Rio de Janeiro, 1995. Dissertação (Mestrado) - Centro de PósGraduação em Desenvolvimento Agricola/UFRRJ.

SILVA, J.C.F.da. Origens, evolução e estágio atual da crise econômica Perspectivas da economia brasileira - 1992. Rio de Janeiro: IPEA, 1991. p. 5-19.

SILVEIRA, A.P.D., SILVA, L.R.C., LOMBARDI, M.L.C.O., DECHEN, S.C.F.; LOMBARDI NETO, F. Atividade microbiana em solo submetido à erosão simulada sob processo de recuperação. In: CONGRESSO BRASILEIRO DE MICROBIOLOGIA, 17., Santos, SP, 1993. Resumos.

SOLÓRZANO, R. et al. Accounts overdue: natural resource depreciation in Costa Rica. Washington: World Resource Institute, 1991.

SPAROVECK, G.; TERRAMOTO, E.R.; TORETA, D.M.; ROCHELE, T.C.P.; SAYER, E.P.M. Erosão simulada e a produtividade da cultura do milho. R. Bras. Ci.Solo, Campinas, v. 15, n. 3, p. 363-368, 1991.

SPAROVECK, G; VAN LIER, Q. de J.; ALOISI, R.R.; VIDAL-TORRADO, P. Proposta de avaliação do rendimento de uma cultura em função da erosão do solo. In: REUNIÃO BRASILEIRA DE MANEJO E CONSERVAÇÃO DO SOLO E DA ÁGUA, 9., Jaboticabal, SP, 1992. Programas e Resumos. Jaboticabal, São Paulo. 1992. $208 \mathrm{p}$.

THEYS, J. Environmental accounting in development policy: the French experience. In: 
AHMAD, Y.J.; EL SERAFY, S.; LUTZ, E., ed. Environmental accounting for sustainahle development. 3.ed. Washington: The World Bank, 1992. p.40-53.

VAN RAIJ, B. Avaliação da fertilidade do solo. Piracicaba: POTAFOS, 1987.

VAN TONGEREN, J.; SCHWEINFEST, S.; LUTZ, E.; LUNA, M.G.; MARTIN, F.G. Integrated environmental and economic accounting: a case study for Mexico. Washington: The World Bank. Sector Policy and Research Staff, 1991. (Environment working paper, n. 50)

VASQUES FILHO, J. Erosão e seu controle. In: MARCONI, A., coord. Curso de atualização em solos. Piracicaba: ESALQ/FEALQ/LSG, 1986. (Programa de treinamento BANESPA)

VELOZ, A.; SOUTHGATE, D.; HITZHUSEN, F.; MACGREGOR, R. The economics of erosion control in a subtropical watershed: a Dominican case. Land Economics, Wisconsin, v. 61, n. 2, p. 145-155, may 1985. 
111.

APÊNDICE 


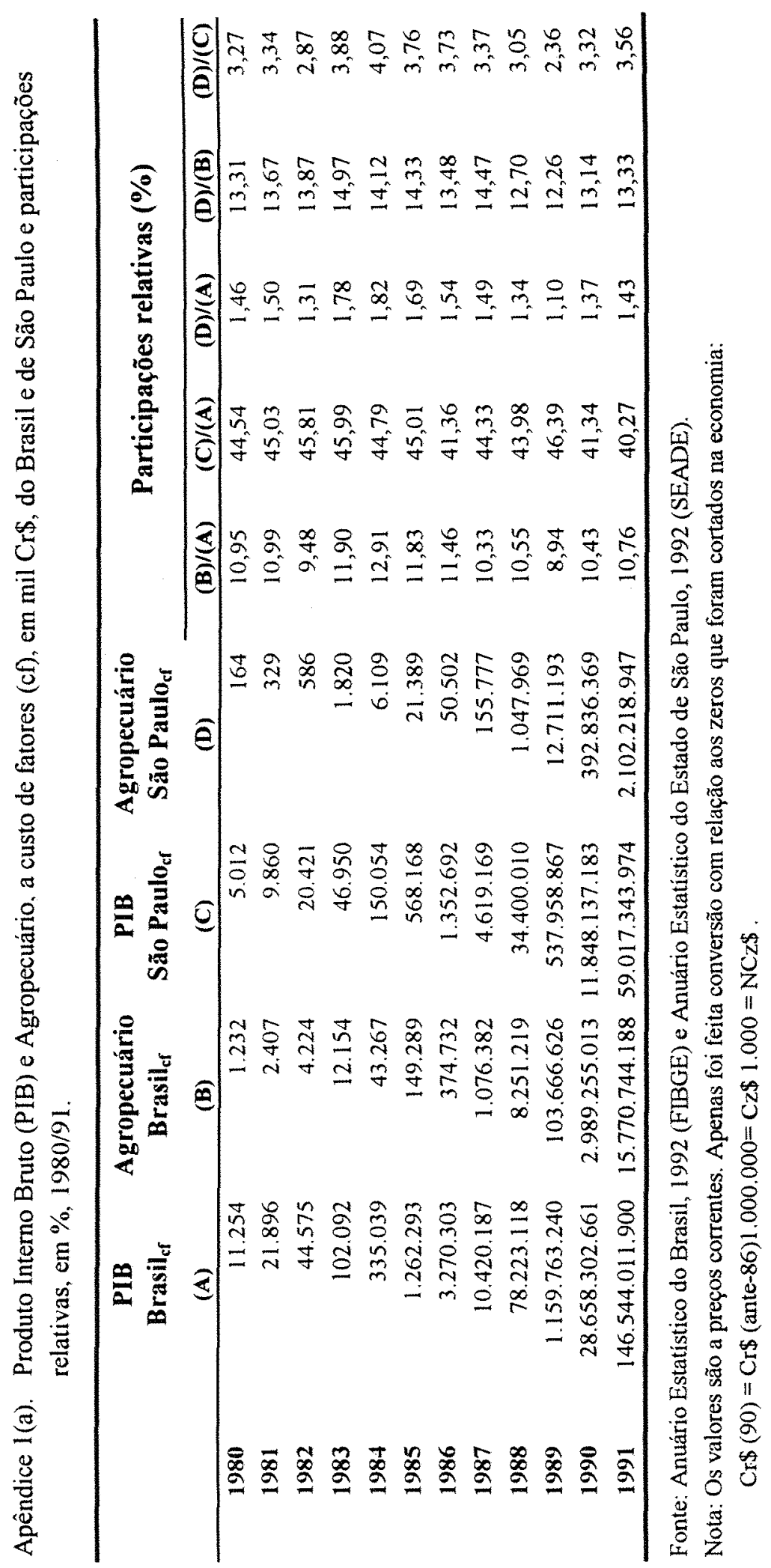


113.

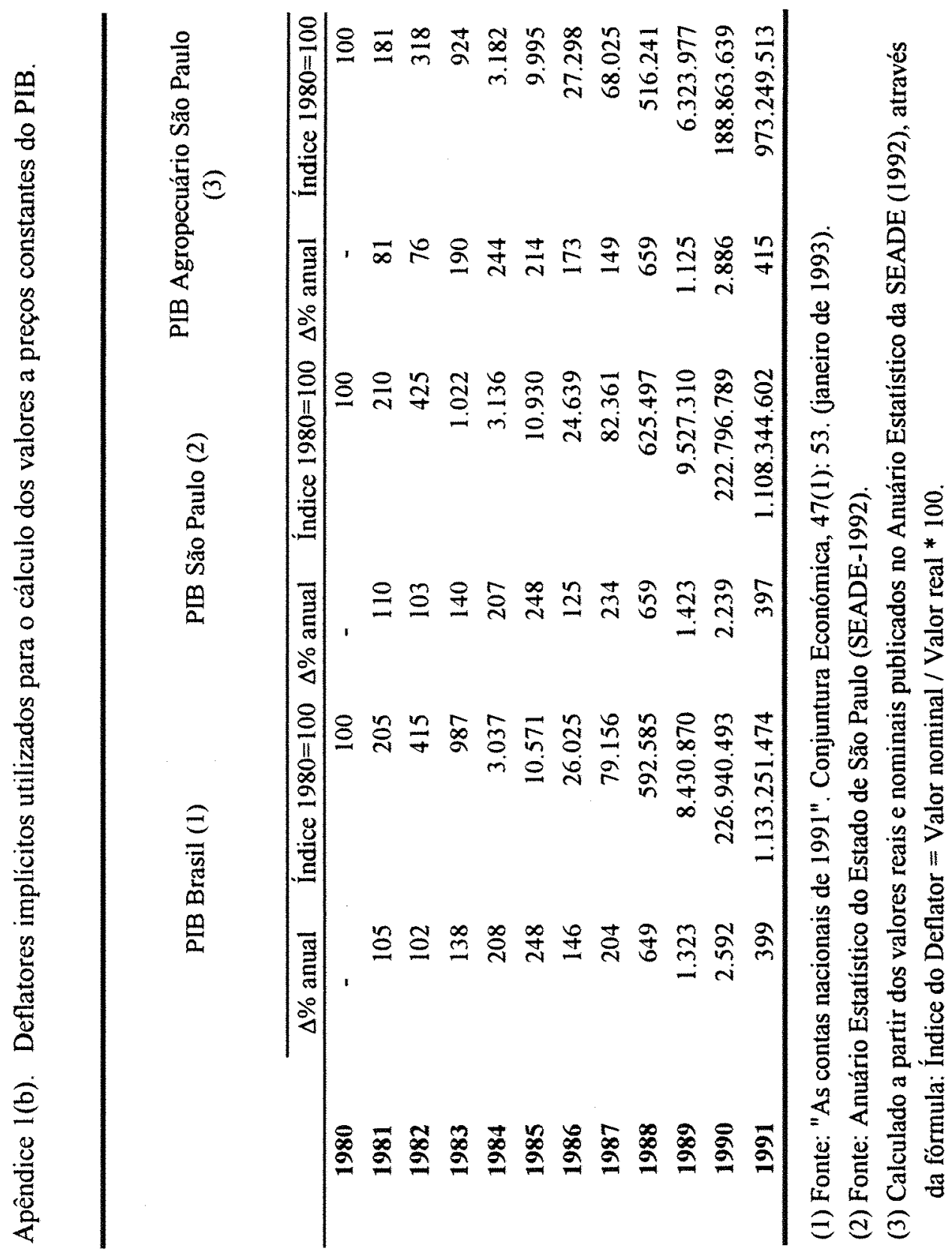


114.

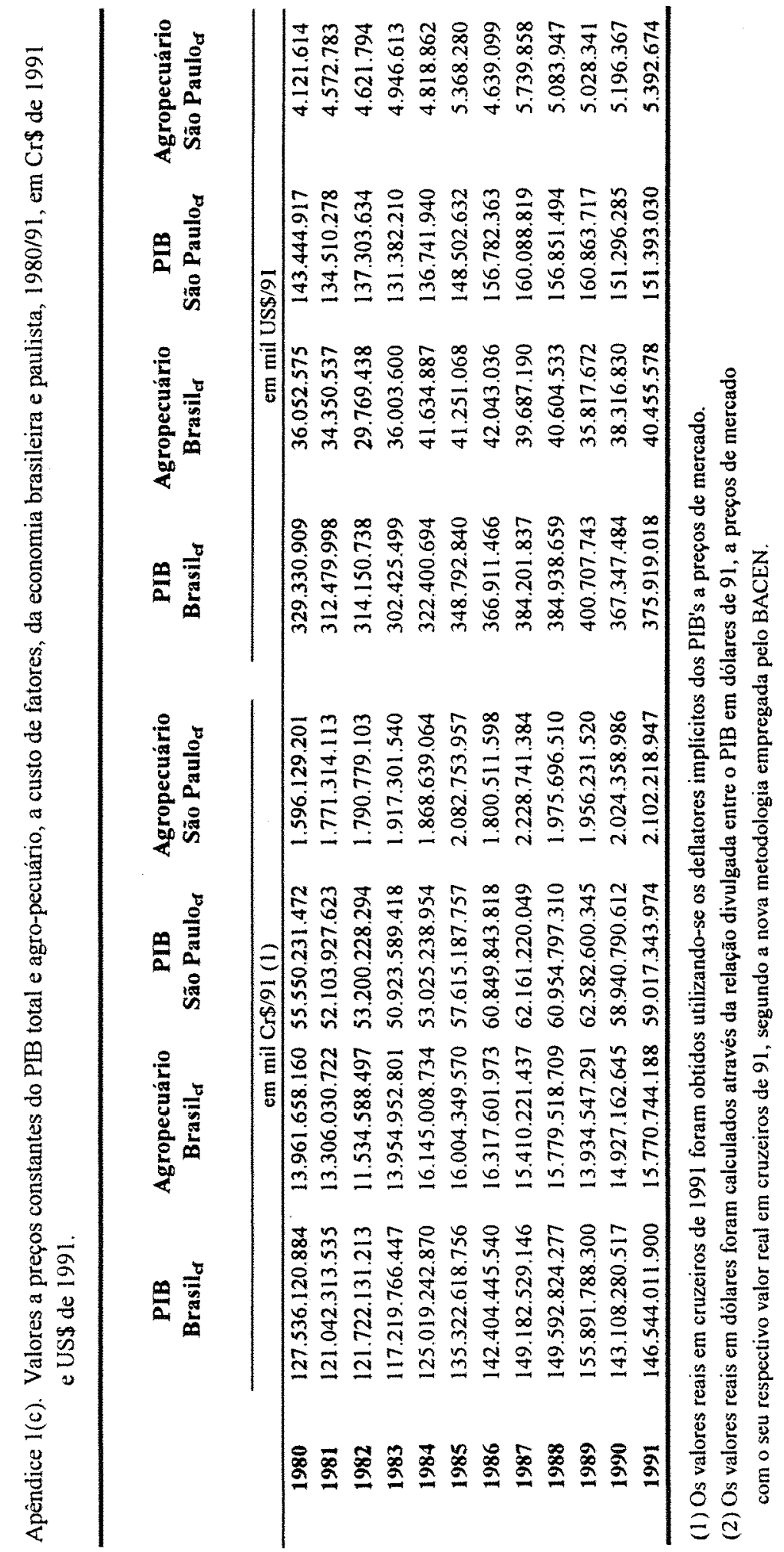




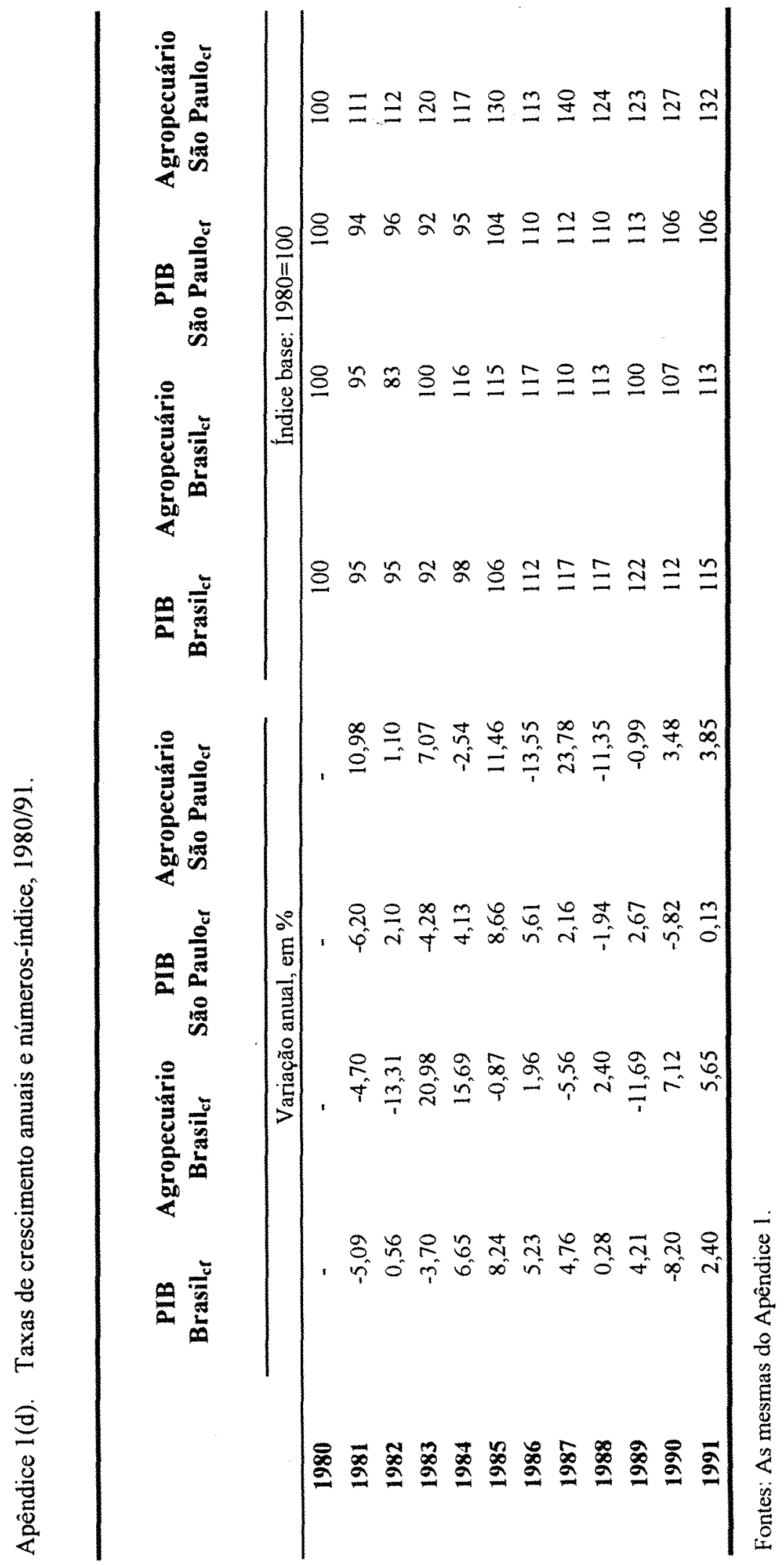




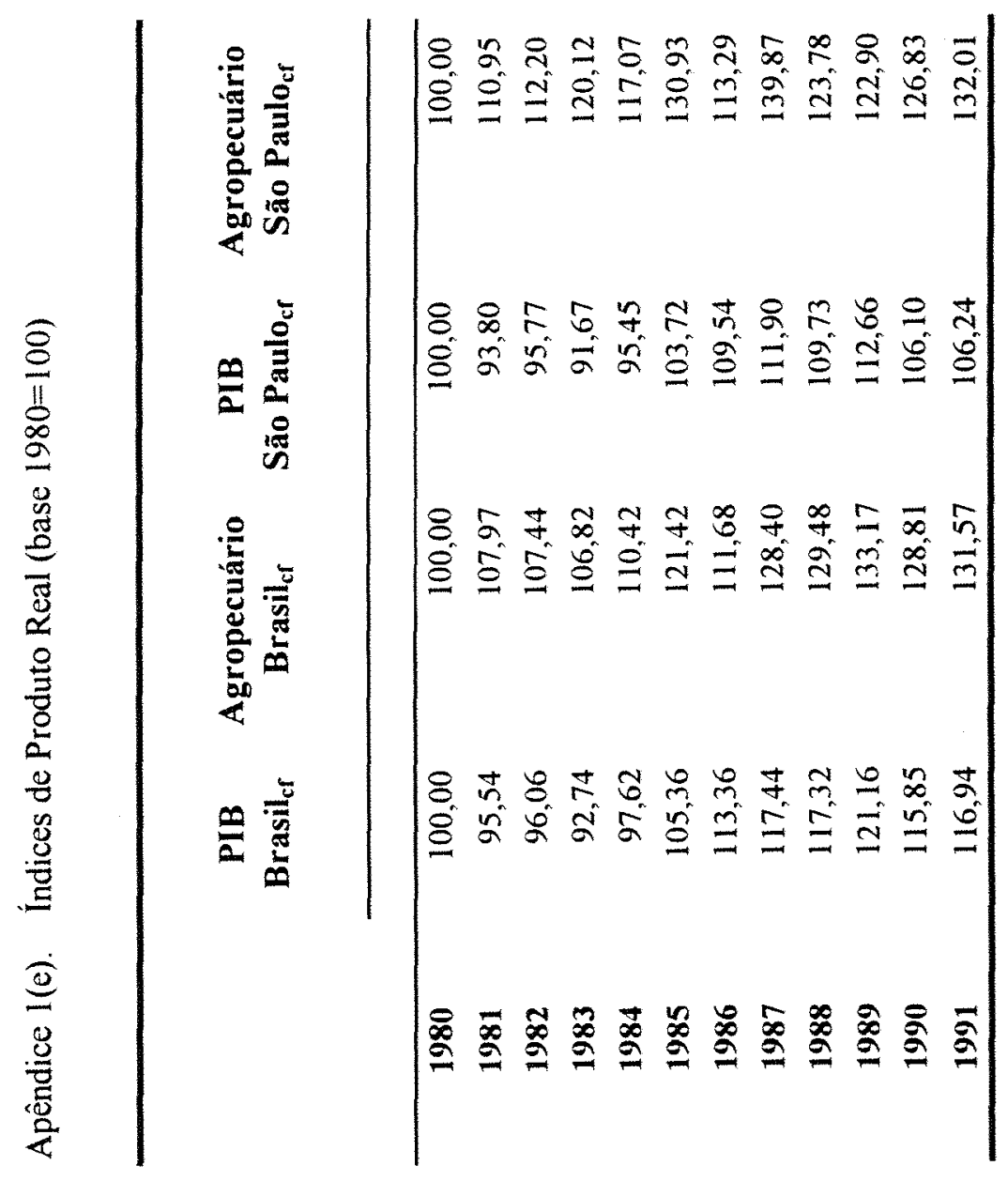




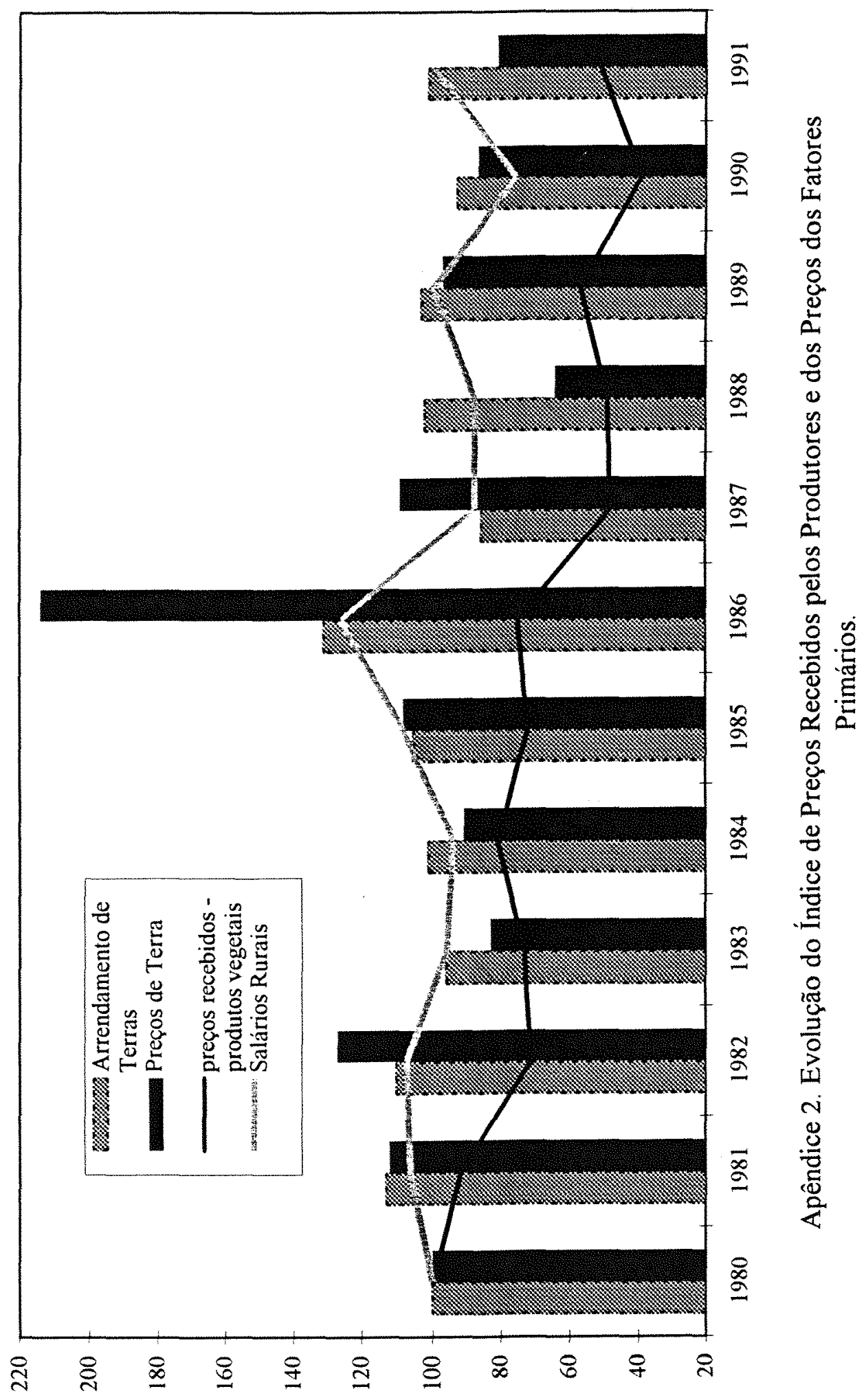


118.

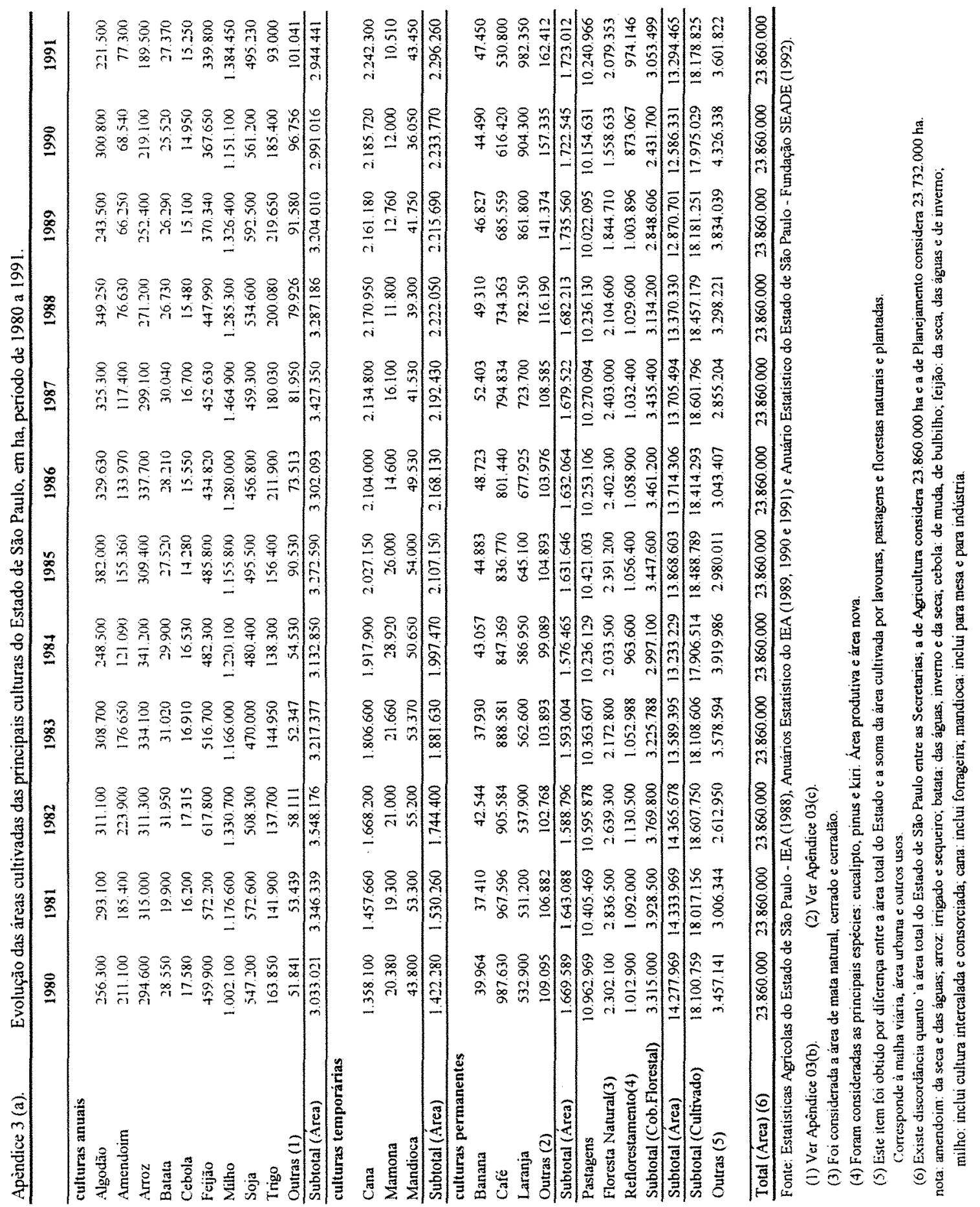


119.

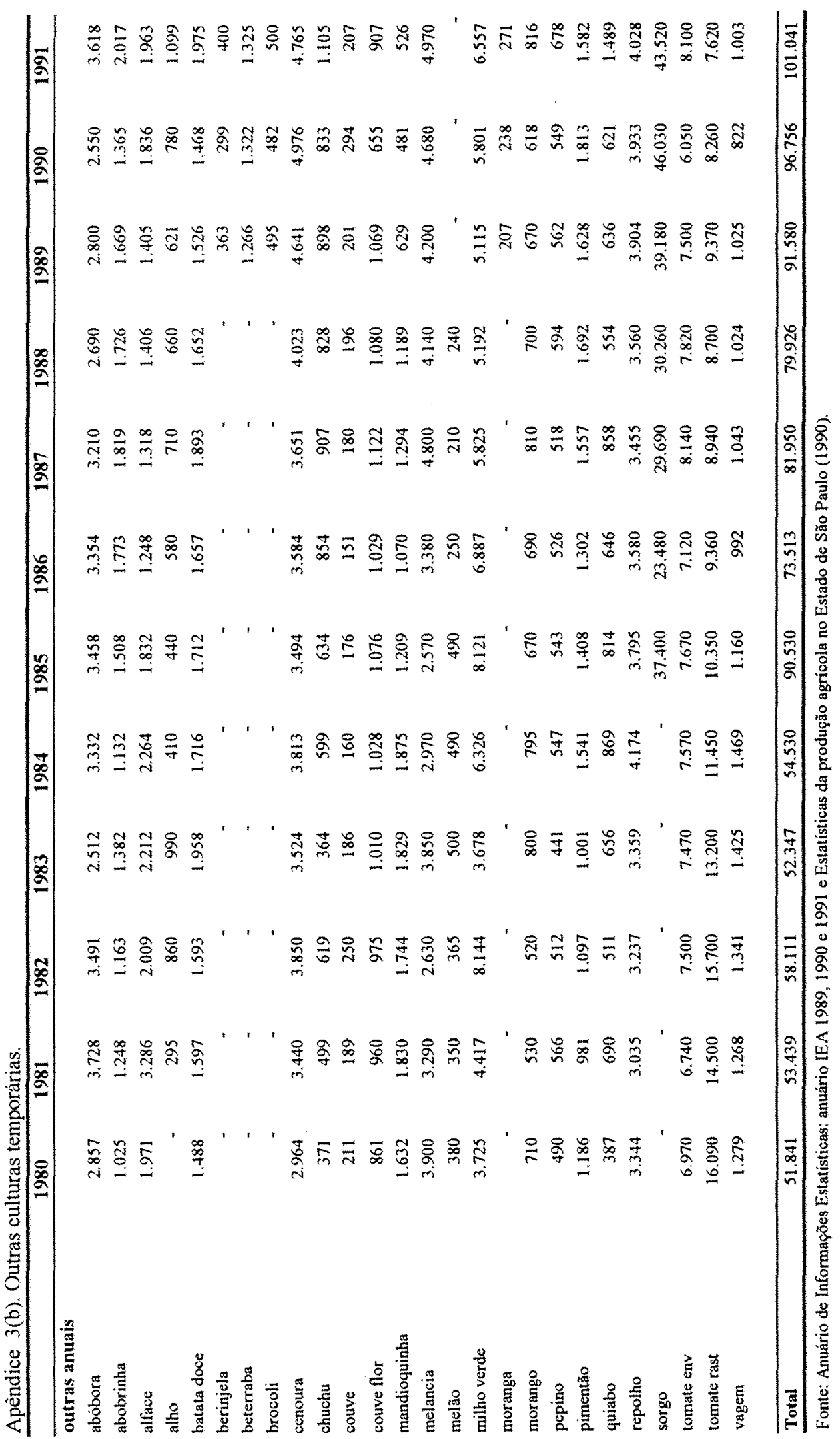


120.

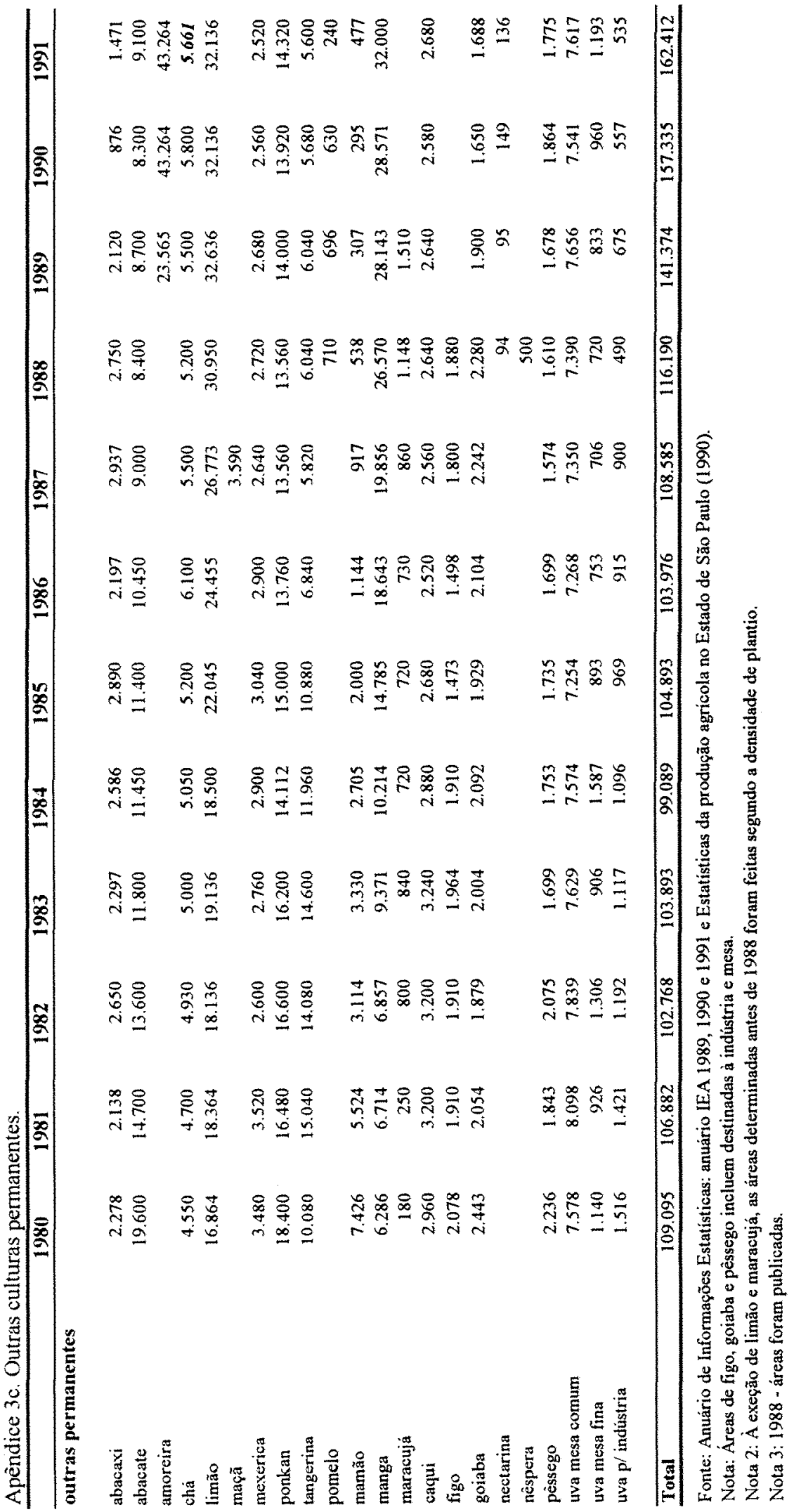




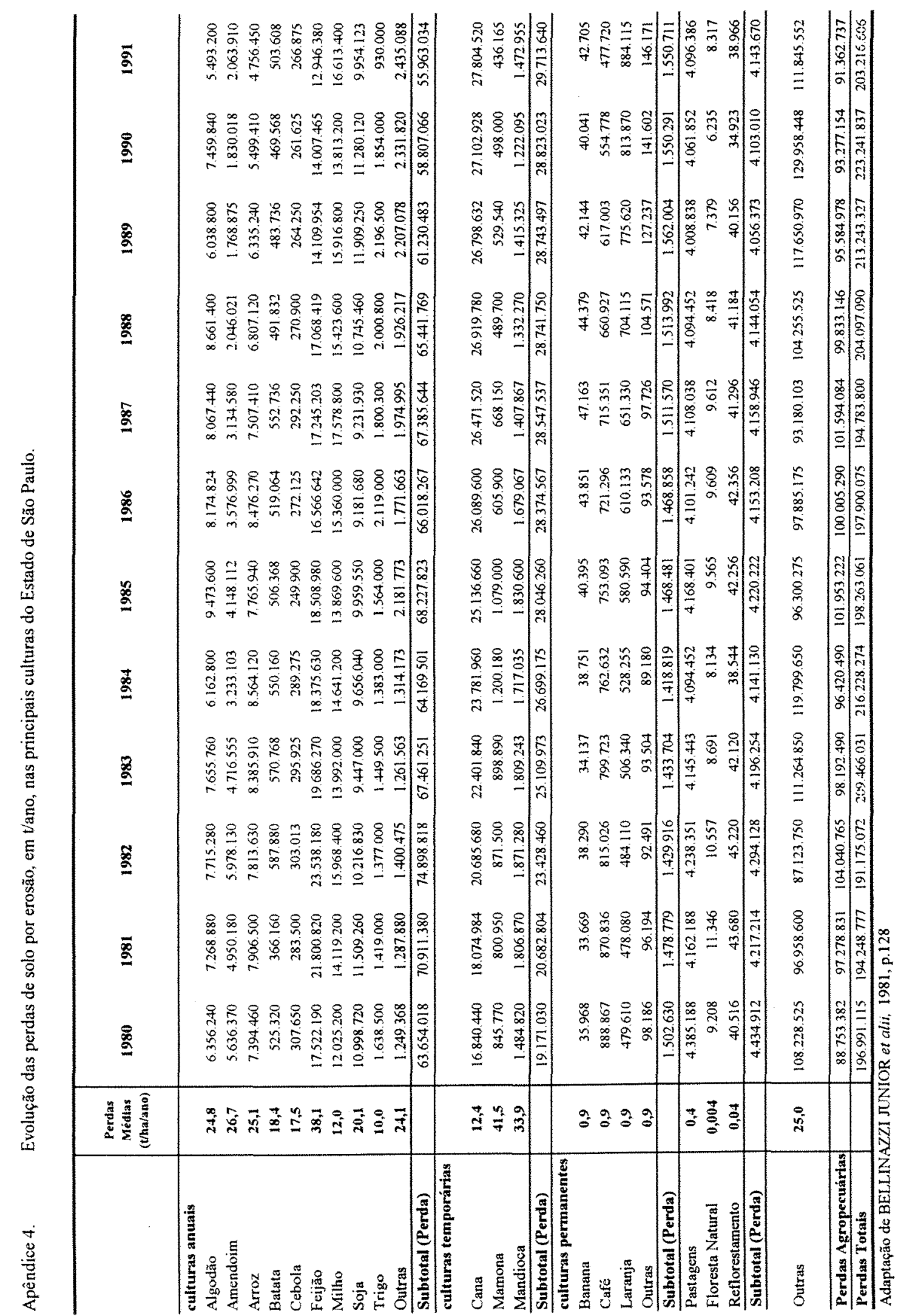


Apêndice 5 (a). Série do Índice Geral de Prę̧os - Disponibilidade Interna (IGP-DD) utilizada para a correção dos valores nominais presentes na dissertação. Índice na base ago. $94=100$, expresso em notação cientifica.

\begin{tabular}{|c|c|c|c|c|c|c|c|}
\hline mês/ano & ago.94 $=100$ & mês/ano & $\begin{array}{c}\text { ago. } .94= \\
100\end{array}$ & mês/ano & $\begin{array}{c}\text { ago.94 }= \\
100\end{array}=$ & mês/ano & $\begin{array}{c}\text { ago. } 94= \\
100\end{array}$ \\
\hline jan-80 & 5.8602 E-10 & jan-83 & 4,9299 E-09 & jan-86 & 1,7970 E-07 & jan-89 & $2,0176 \mathrm{E}-05$ \\
\hline fev-80 & $6,1062 \mathrm{E}-10$ & fev-83 & $5,2513 \mathrm{E}-09$ & fev-86 & 2,0662 E-07 & fev-89 & $2,2557 \mathrm{E}-05$ \\
\hline $\operatorname{mar}-80$ & $6,5075 \mathrm{E}-10$ & $\operatorname{mar}-83$ & 5,7810 E-09 & $\operatorname{mar}-86$ & 2,1803 E-07 & $\operatorname{mar}-89$ & $2,3511 \mathrm{E}-05$ \\
\hline abr- 80 & 6,8801 E- 10 & $a b r-83$ & $6,3127 \mathrm{E}-09$ & $a b r-86$ & 2,1677 E-07 & abr-89 & 2,4726 E-05 \\
\hline mai-80 & $7,3198 \mathrm{E}-10$ & mai-83 & $6,7167 \mathrm{E}-09$ & mai-86 & $2,1746 \mathrm{E}-07$ & mai-89 & $2,7881 \mathrm{E}-05$ \\
\hline jun-80 & $7,7490 \mathrm{E}-10$ & jun-83 & 7,5633 E-09 & jun-86 & $2,1861 \mathrm{E}-07$ & jun-89 & $3,5343 \mathrm{E}-05$ \\
\hline jul-80 & 8,4035 E-10 & jul-83 & 8,5696 E-09 & jul-86 & $2,1999 \mathrm{E}-07$ & jul-89 & 4,8732 E-05 \\
\hline ago-80 & $8,9848 \mathrm{E}-10$ & ago-83 & 9,4363 E- 09 & ago-86 & $2.2292 \mathrm{E}-07$ & ago-89 & $6,6510 \mathrm{E}-05$ \\
\hline set-80 & 9,4593 E-10 & set -83 & $1,0643 \mathrm{E}-08$ & set-86 & $2,2536 \mathrm{E}-07$ & set-89 & 9,2394 E-05 \\
\hline out-80 & 1.0183 E-09 & out-83 & $1,2055 \mathrm{E}-08$ & out-86 & $2,2848 \mathrm{E}-07$ & out-89 & $1,2907 \mathrm{E}-04$ \\
\hline nov-80 & $1,0951 \mathrm{E}-09$ & nov-83 & $1,3072 \mathrm{E}-08$ & nov -86 & 2,3409 E-07 & nov -89 & $1,8622 \mathrm{E}-04$ \\
\hline dez-80 & $1.1597 \mathrm{E}-09$ & dez-83 & $1,4060 \mathrm{E}-08$ & dez-86 & $2,5178 \mathrm{E}-07$ & dez-89 & $2,7819 \mathrm{E}-04$ \\
\hline jan-81 & $1.2358 \mathrm{E}-09$ & jan-84 & $1.5440 \mathrm{E}-08$ & jan-87 & 2,8209 E-07 & jan-90 & 4,7821 E-04 \\
\hline fev-81 & $1.3406 \mathrm{E}-09$ & fev-84 & 1,7332 E-08 & fev- 87 & $3,2189 \mathrm{E}-07$ & fev -90 & 8.2098 E-04 \\
\hline $\operatorname{mar}-81$ & 1.4393 E-09 & $\operatorname{mar}-84$ & $1,9057 \mathrm{E}-08$ & $\operatorname{mar}-87$ & 3,7017 E-07 & $\operatorname{mar}-90$ & $1,4886 \mathrm{E}-03$ \\
\hline abr-81 & $1.5181 \mathrm{E}-09$ & abr-84 & $2,0761 \mathrm{E}-08$ & abr-87 & 4,4448 E-07 & abr-90 & $1,6573 \mathrm{E}-03$ \\
\hline mai-81 & $1,6121 \mathrm{E}-09$ & mai-84 & 2,2600 E- 08 & mai-87 & $5,6708 \mathrm{E}-07$ & mai-90 & 1,8077 E-03 \\
\hline jun-81 & $1.6841 \mathrm{E}-09$ & jun-84 & $2.4691 \mathrm{E}-08$ & jun-87 & 7,1381 E-07 & jun-90 & $1,9708 \mathrm{E}-03$ \\
\hline jul-81 & $1.7696 \mathrm{E}-09$ & jul-84 & 2,7239 E- 08 & jul-87 & 7,8041 E-07 & jul-90 & $2,2266 \mathrm{E}-03$ \\
\hline ago-81 & 1.8887 E-09 & ago-84 & 3,0132 E-08 & ago-87 & 8,1552 E-07 & ago-90 & $2.5145 \mathrm{E}-03$ \\
\hline set-81 & $1,9845 \mathrm{E}-09$ & set-84 & 3,3299 E-08 & set-87 & 8,8090 E-07 & set -90 & 2,8090 E-03 \\
\hline out-81 & $2.0709 \mathrm{E}-09$ & out -84 & 3,7487 E-08 & out-87 & 9,7910 E-07 & out-90 & $3.2067 \mathrm{E}-03$ \\
\hline nov -81 & $2.1809 \mathrm{E}-09$ & nov-84 & 4,1190 E-08 & nov-87 & $1,1207 \mathrm{E}-06$ & nov-90 & $3,7663 \mathrm{E}-03$ \\
\hline dez-81 & 2.2637 E-09 & dez-84 & $4,5528 \mathrm{E}-08$ & dez-87 & $1,2988 \mathrm{E}-06$ & dez-90 & $4.3862 \mathrm{E}-03$ \\
\hline jan-82 & $2,4059 \mathrm{E}-09$ & jan-85 & 5,1281 E-08 & jan-88 & $1,5474 \mathrm{E}-06$ & jan-91 & $5,2604 \mathrm{E}-03$ \\
\hline fev-82 & 2.5707 E-09 & fev-85 & 5,6492 E-08 & fev-88 & $1,8205 \mathrm{E}-06$ & fev-91 & $6,3709 \mathrm{E}-03$ \\
\hline $\operatorname{mar}-82$ & $2.7566 \mathrm{E}-09$ & mar-85 & $6,3671 \mathrm{E}-08$ & $\operatorname{mar}-88$ & $2,1511 \mathrm{E}-06$ & $\operatorname{mar}-91$ & $6,8328 \mathrm{E}-03$ \\
\hline abr-82 & $2.9043 \mathrm{E}-09$ & abr-85 & $6,8266 \mathrm{E}-08$ & abr-88 & 2.5885 E-06 & abr-91 & $7,4299 \mathrm{E}-03$ \\
\hline mai-82 & $3.0820 \mathrm{E}-09$ & mai-85 & 7,3578 E-08 & mai-88 & 3,0935 E-06 & mai-91 & $7,9151 \mathrm{E}-03$ \\
\hline jun-82 & 3,3283 E-09 & jun-85 & 7,9350 E-08 & jun-88 & 3,7378 E-06 & jun-91 & $8,6955 \mathrm{E}-03$ \\
\hline jul-82 & $3,5300 \mathrm{E}-09$ & jul-85 & $8,6425 \mathrm{E}-08$ & jul-88 & 4,5429 E-06 & jul-91 & $9,8112 \mathrm{E}-03$ \\
\hline ago-82 & 3.7348 E-09 & ago-85 & 9,8523 E-08 & ago-88 & 5,5830 E-06 & ago-91 & $1,1331 \mathrm{E}-02$ \\
\hline set-82 & $3,8714 \mathrm{E}-09$ & set-85 & $1,0752 \mathrm{E}-07$ & set-88 & $7,0211 \mathrm{E}-06$ & set-91 & $1,3165 E-02$ \\
\hline out-82 & 4.0564 E-09 & out-85 & $1,1725 \mathrm{E}-07$ & out-88 & 8,9578 E-06 & out-91 & $1,6569 \mathrm{E}-02$ \\
\hline nov -82 & $4,2594 \mathrm{E}-09$ & nov-85 & 1,3478 E-07 & nov-88 & $1,1463 \mathrm{E}-05$ & nov-91 & $2.0837 \mathrm{E}-02$ \\
\hline de $z-82$ & $4.5210 \mathrm{E}-09$ & dez-85 & $1.5257 \mathrm{E}-07$ & de $x-88$ & $1.4775 \mathrm{E}-05$ & dez-91 & $2.5450 \mathrm{E}-02$ \\
\hline
\end{tabular}

Fonte: FGV. 
Apêndice 5(b). Série do Índice Geral de Preços - Disponibilidade Interna (IGP-DI) utilizada para a correção dos valores nominais presentes na dissertação. Variações mensais percentuais.

\begin{tabular}{|c|c|c|c|c|c|c|c|}
\hline mês/ano & em \% & mês/ano & $\mathrm{em} \%$ & mês/ano & em $\%$ & mês/ano & em \% \\
\hline jan-80 & 6,24 & jan-83 & 9,05 & jan-86 & 17,79 & jan-89 & 36,56 \\
\hline fev-80 & 4,20 & fev-83 & 6,52 & fev-86 & 14,98 & fev-89 & 11,80 \\
\hline $\operatorname{mar}-80$ & 6,57 & $\operatorname{mar}-83$ & 10,09 & $\operatorname{mar}-86$ & 5,52 & $\operatorname{mar}-89$ & 4,23 \\
\hline abr-80 & 5,72 & abr-83 & 9,20 & abr-86 & $(0,58)$ & abr-89 & 5,17 \\
\hline mai-80 & 6,39 & mai-83 & 6,40 & mai-86 & 0,32 & mai-89 & 12,76 \\
\hline jun-80 & 5,86 & jun-83 & 12,61 & jun-86 & 0,53 & jun-89 & 26,76 \\
\hline jul-80 & 8,45 & jul-83 & 13,31 & jul-86 & 0,63 & jul-89 & 37,88 \\
\hline ago-80 & 6,92 & ago-83 & 10,11 & ago-86 & 1,33 & ago-89 & 36,48 \\
\hline set-80 & 5,28 & set- 83 & 12,79 & set-86 & 1,09 & set-89 & 38,92 \\
\hline out-80 & 7,65 & out-83 & 13,26 & out-86 & 1,39 & out-89 & 39,70 \\
\hline nov -80 & 7,55 & nov -83 & 8,43 & nov-86 & 2,46 & nov-89 & 44,27 \\
\hline dez-80 & 5,89 & dez-83 & 7,56 & dez-86 & 7,56 & dez-89 & 49,39 \\
\hline jan-81 & 6,56 & jan-84 & 9,81 & jan-87 & 12,04 & jan-90 & 71,90 \\
\hline fev-81 & 8,48 & fev-84 & 12,26 & fev-87 & 14,11 & fev-90 & 71,68 \\
\hline $\operatorname{mar}-81$ & 7,37 & mar-84 & 9,95 & $\operatorname{mar}-87$ & 15,00 & $\operatorname{mar}-90$ & 81,32 \\
\hline abr-81 & 5,47 & abr-84 & 8,94 & abr-87 & 20,08 & abr -90 & 11,33 \\
\hline mai-81 & 6,19 & mai-84 & 8,86 & mai-87 & 27,58 & mai-90 & 9,08 \\
\hline jun-81 & 4,47 & jun-84 & 9,25 & jun-87 & 25,88 & jun-90 & 9,02 \\
\hline jul-81 & 5,08 & jul-84 & 10,32 & jul-87 & 9,33 & jul-90 & 12,98 \\
\hline ago-81 & 6,73 & ago-84 & 10,62 & ago- -87 & 4,50 & ago-90 & 12,93 \\
\hline set- 81 & 5,07 & set-84 & 10,51 & set-87 & 8,02 & set-90 & 11,71 \\
\hline out-81 & 4,35 & out-84 & 12,58 & out-87 & 11,15 & out-90 & 14,16 \\
\hline nov-81 & 5,31 & nov -84 & 9,88 & nov-87 & 14,47 & nov -90 & 17,45 \\
\hline dez-81 & 3,80 & dez-84 & 10,53 & dez-87 & 15,89 & dez-90 & 16,46 \\
\hline jan-82 & 6,29 & jan-85 & 12,64 & jan-88 & 19,14 & jan-91 & 19,93 \\
\hline fev-82 & 6,85 & fev-85 & 10,16 & fev-88 & 17,65 & fev-91 & 21,11 \\
\hline mar-82 & 7,23 & mar-85 & 12,71 & mar-88 & 18,16 & $\operatorname{mar}-91$ & 7,25 \\
\hline abr-82 & 5,36 & abr-85 & 7,22 & abr-88 & 20,33 & abr-91 & 8,74 \\
\hline mai-82 & 6,12 & mai-85 & 7,78 & mai-88 & 19,51 & mai-91 & 6,53 \\
\hline jun-82 & 7,99 & jun-85 & 7,84 & jun-88 & 20,83 & jun-91 & 9,86 \\
\hline jul-82 & 6,06 & jul-85 & 8,92 & jul-88 & 21,54 & jul-91 & 12,83 \\
\hline ago-82 & 5,80 & ago-85 & 14,00 & ago-88 & 22,89 & ago-91 & 15,49 \\
\hline set-82 & 3,66 & set-85 & 9,13 & set-88 & 25,76 & set-91 & 16,19 \\
\hline out-82 & 4,78 & out-85 & 9,05 & out-88 & 27,58 & out-91 & 25,85 \\
\hline nov-82 & 5,00 & nov-85 & 14,95 & nov -88 & 27,97 & nov-91 & 25,76 \\
\hline dez-82 & 6,14 & dez -85 & 13,20 & dez-88 & 28,89 & dez-91 & $2.2,14$ \\
\hline
\end{tabular}

Fonte: FGV. 
Apêndice 6.Série da taxa de câmbio, dólar comercial de venda, média do mês, em valores constantes de 1991, corrigidos pelo IGP-DI.

\begin{tabular}{|c|c|c|c|c|c|c|c|}
\hline mês/ano & $\begin{array}{c}\text { câmbio } \\
\text { (em Cr\$91) }\end{array}$ & mês/ano & $\begin{array}{l}\text { câmbio } \\
\text { (em Cr\$91) }\end{array}$ & mês/ano & $\begin{array}{c}\text { câmbio } \\
\text { (em Cr\$91) }\end{array}$ & mês/ano & $\begin{array}{c}\text { câmbio (em } \\
\text { CrS91) }\end{array}$ \\
\hline jan-80 & 866,79 & jan-83 & 621,37 & jan-86 & 732,52 & jan-89 & 520,93 \\
\hline fev-80 & 855,11 & fev-83 & 699.35 & fev-86 & 733,92 & fev-89 & 515,98 \\
\hline $\operatorname{mar}-80$ & 831,96 & $\operatorname{mar}-83$ & 806,47 & $\operatorname{mar}-86$ & 738,80 & $\operatorname{mar}-89$ & 495,05 \\
\hline$a b r-80$ & 817,49 & $a b r-83$ & 802,52 & abr-86 & 743,12 & abr-89 & 477,77 \\
\hline mai-80 & 791.70 & mai-83 & 822.46 & mai-86 & 740,75 & mai-89 & 458,78 \\
\hline jun-80 & 771,45 & jun-83 & 796,79 & jun-86 & 736,86 & jun-89 & 440,29 \\
\hline jul-80 & 731,94 & jul-83 & 774,65 & jul-86 & 732,23 & jul-89 & 457,13 \\
\hline ago-80 & 707.88 & ago-83 & 793,51 & ago-86 & 722,60 & ago-89 & 433,12 \\
\hline set-80 & 696,52 & set-83 & 766,99 & set-86 & 714,79 & set-89 & 411,55 \\
\hline out -80 & 671,90 & out-83 & 758,19 & out-86 & 711,64 & out-89 & 404,88 \\
\hline nov-80 & 651.71 & nov-83 & 775,57 & nov-86 & 701,40 & nov-89 & 390,51 \\
\hline dez-80 & 641.03 & dez-83 & 783.22 & dez-86 & 672.40 & dez-89 & 387,38 \\
\hline jan-81 & 635.93 & jan-84 & 769,70 & jan-87 & 647.69 & jan-90 & 348,36 \\
\hline fev-81 & 612,17 & fev-84 & 759,32 & fev-87 & 655,77 & fev-90 & 335,44 \\
\hline mar-81 & 601,39 & $\operatorname{mar}-84$ & 775,76 & $\operatorname{mar}-87$ & 660,48 & $\operatorname{mar}-90$ & 294,77 \\
\hline abr-81 & 605,40 & $a b r-84$ & 778,02 & abr-87 & 620,78 & abr-90 & 336,33 \\
\hline mai-81 & 606.75 & mai-84 & 778,01 & mai-87 & 631,79 & mai-90 & 336,28 \\
\hline jun-81 & 2,83 & jun-84 & 775,31 & jun-87 & 643,09 & jun-90 & 337,31 \\
\hline jul-81 & 617,99 & jul-84 & 775,97 & jul-87 & 670,14 & jul-90 & 347,70 \\
\hline ago-81 & 5,75 & ago-84 & 770,33 & ago-87 & 672,63 & ago-90 & 332,14 \\
\hline set-81 & & set -84 & 770,35 & set-87 & 658,86 & set -90 & 313,00 \\
\hline out-81 & 626,48 & out-84 & 761,84 & out-87 & 634,87 & out-90 & 345,41 \\
\hline nov-81 & 9,51 & nov-84 & 772,69 & nov-87 & 615,73 & nov- 90 & 380,52 \\
\hline dez-81 & & dez-84 & 769,12 & dez-87 & 604,72 & dez-90 & 391.22 \\
\hline jan-82 & & jan-85 & 763,47 & jan-88 & 584.09 & jan-91 & 428,60 \\
\hline fev-82 & .44 & fev-85 & 775,52 & fev-88 & 580,79 & fev-91 & 405,18 \\
\hline mar-82 & & $\operatorname{mar}-85$ & 760,51 & $\operatorname{mar}-88$ & 579,69 & mar-91 & 392.23 \\
\hline abr-82 & 610.05 & abr-85 & 804,38 & abr-88 & 565.14 & abr-91 & 395,34 \\
\hline mai-82 & 604.15 & mai-85 & 828,31 & mai-88 & 566,76 & mai-91 & 401,82 \\
\hline jun-82 & 8.65 & jun-85 & 842.24 & jun-88 & 555,20 & jun-91 & 399.04 \\
\hline jul-82 & & jul-85 & 837,66 & jul-88 & 552.94 & jul-91 & 390.67 \\
\hline ago-82 & 589,33 & ago-85 & 792,84 & ago-88 & 557,46 & ago-91 & 381,80 \\
\hline set-82 & 607,56 & set-85 & 807,71 & set-88 & 540.80 & set-91 & 379.77 \\
\hline out-82 & 618.87 & out-85 & 812,66 & out-88 & 534,92 & out-91 & 410,14 \\
\hline nov-82 & 628.37 & nov-85 & 771,04 & nov-88 & 534,22 & nov-91 & 413,67 \\
\hline dez-82 & 631.83 & dez-85 & 756,17 & dez-88 & 528,62 & dez-91 & 439,03 \\
\hline
\end{tabular}

Fonte: Cotações do dólar comercial, venda. média mensal - FGV.

Correção monetária calculada pelo autor. 
125.

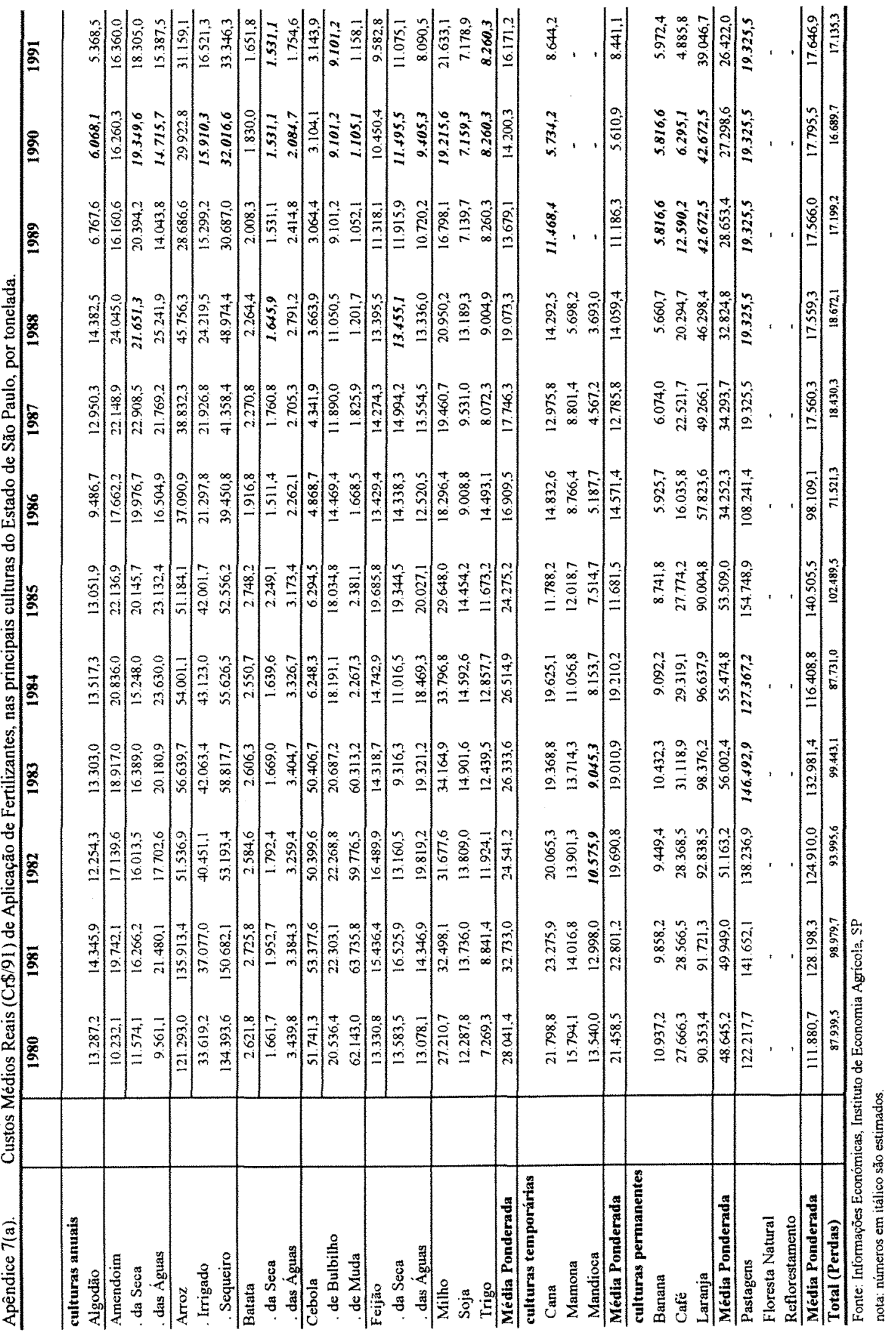


126.

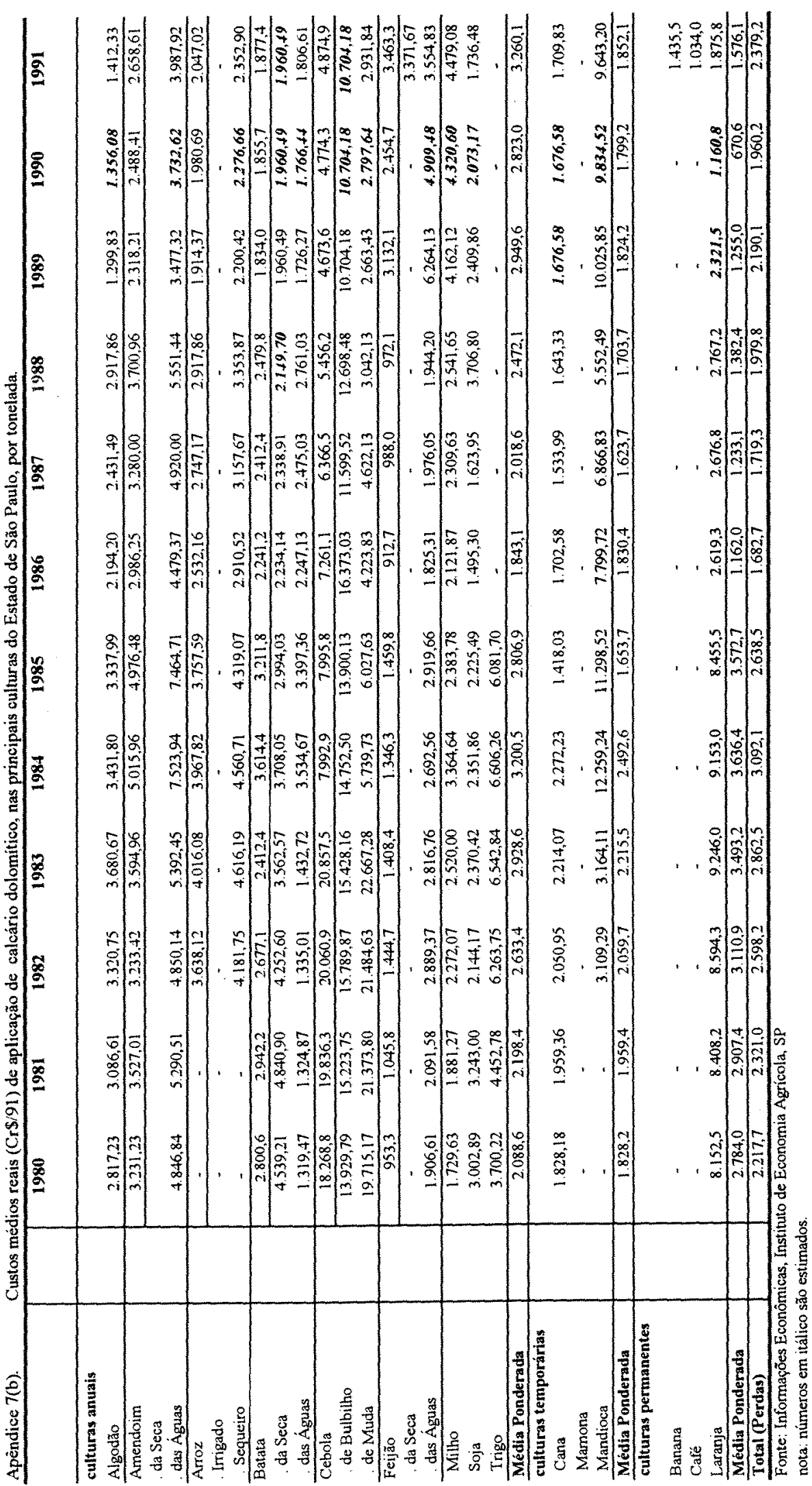




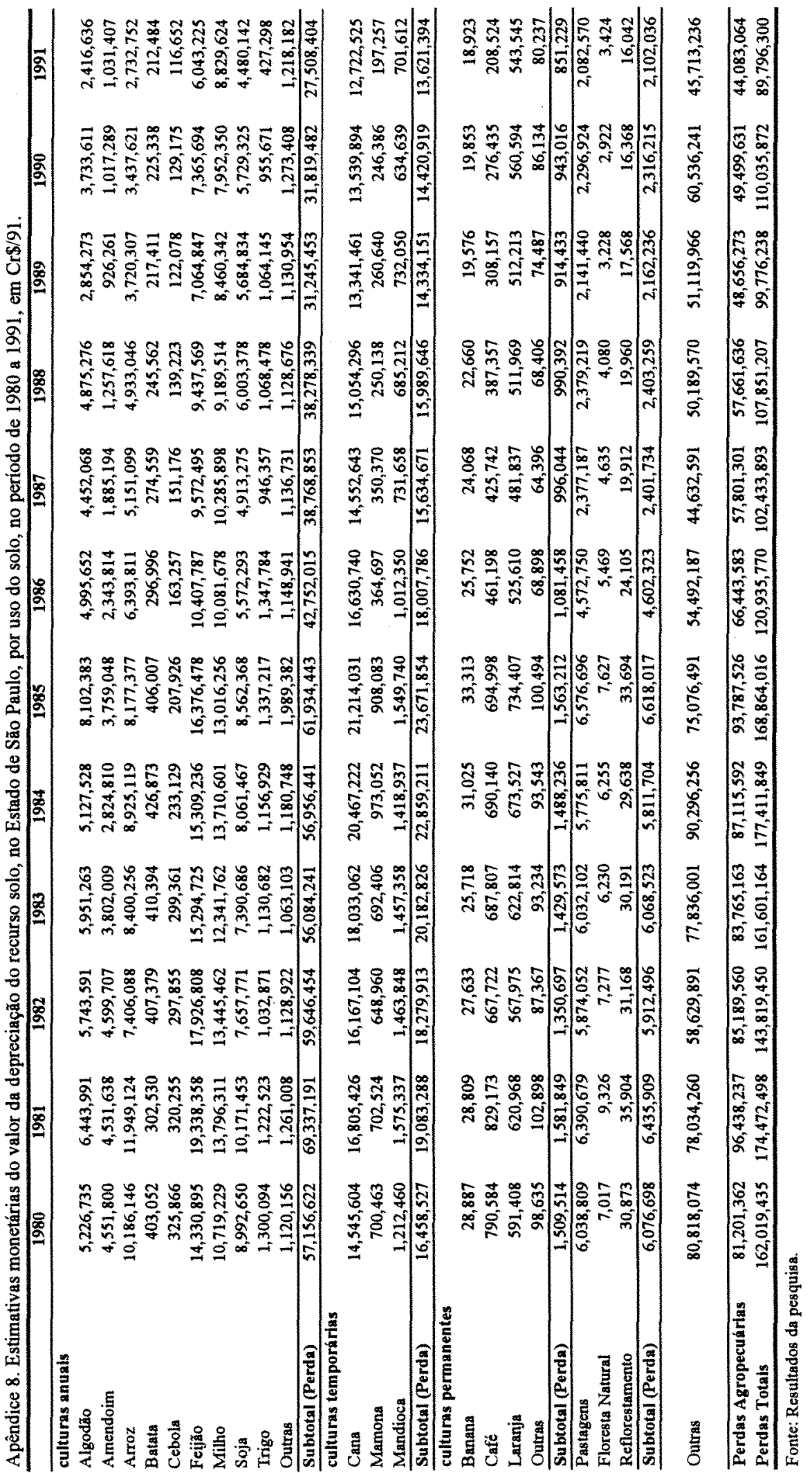

